\title{
Modeling of Integrated Environmental Control Systems for Coal-Fired Power Plants
}

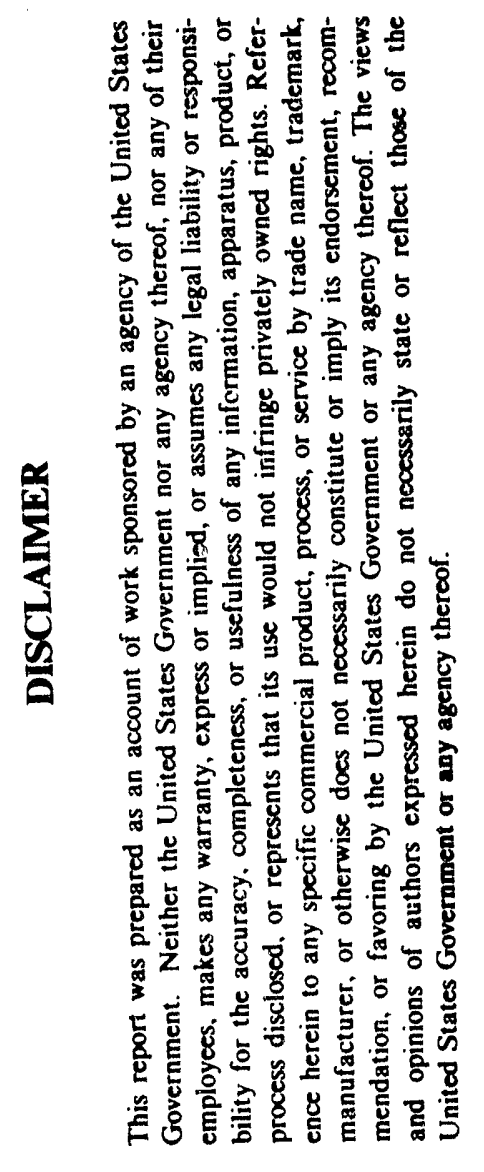

Quarterly Progress Report

To

Pittsburgh Energy Technology Center

U.S. Department of Energy

Pittsburgh, Pennsylvania 15236

From

Center for Energy and Environmental Studies Carnegie Mellon University

Pittsburgh, Pennsylvania 15213

Prepared by

E.S. Rubin, Principal Investigator
MASTER

June 1988

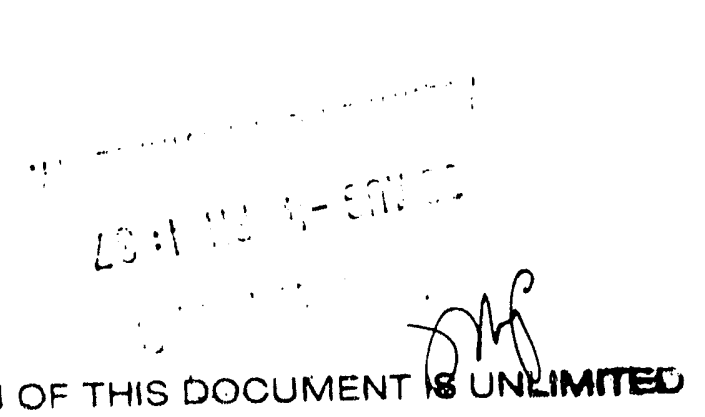




\section{Nomenclature}

\section{English Letter Symbols}

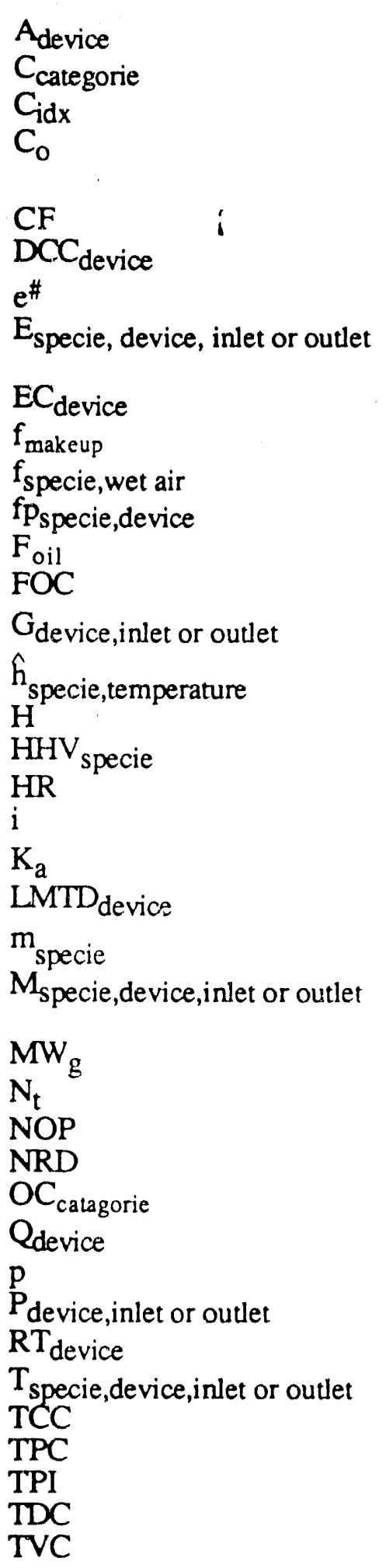

$=$ area of device $\left(\mathrm{ft}^{2}\right)$

= capital charges associated with startup (\$)

$=$ chemical engineering cost index

$=$ molar gas concentration of $\mathrm{SO}_{2}$ in the fluegas entering the adsorber $\left(\mathrm{lbmole} / \mathrm{ft}^{3}\right)$

= capacity factor of power plant (fraction)

= capital cost for device (M\$)

$=$ notation for specifying power of 10 .

= energy flow rate of specie for the inlet or outlet of the specified device (lbmole/hr)

$=$ electricity consumption of the specified device $(\mathrm{kW})$

$=$ attrition rate of sorbent (fraction)

$=$ amount of specie in ambient moist air (fraction)

= quantity of specie produced in device (fraction)

= constant used to estimate amount of sulfur from oil (fraction)

$=$ fixed operating cost $(\$ / y r)$

= gas flow rate for the inlet or outlet of the specified device $\left(\mathrm{ft}^{3} / \mathrm{min}\right)$

$=$ molar enthalpy of species at specified temperature (Btu/lbmole)

$=$ fluidized bed height in adsorber $(\mathrm{ft})$

$=$ higher heating value of specie $(\mathrm{Btu} / \mathrm{b})$

= heat rate of power plant $(\mathrm{kW}-\mathrm{Hr} / \mathrm{MBtu})$

$=$ inflation rate (fraction)

$=$ apparent rate constant $\left(\mathrm{atm}^{-1} \mathrm{sec}^{-1}\right)$

$=\log$ mean temperature difference of device $\left({ }^{\circ} \mathrm{F}\right)$

$=$ mass flow of species $(\mathrm{lbs} / \mathrm{hr}$ or tons $/ \mathrm{hr}$ )

$=$ molar flow rate of specie for the inlet or outlet of the specified device $(\mathrm{lbmole} / \mathrm{hr})$

= gross electrical capacity of power plant (MW)

$=$ initial loading of the active $\mathrm{Na}$ on sorbent $(\mathrm{lbmole} / \mathrm{lb})$

$=$ number of operating adsorbers

= nurnber of spare adsorbers

$=$ annual operating cost $(\$ / y r)$

$=$ heat load across heat exchanger device $(\mathrm{Rtu} / \mathrm{hr})$

$=$ interest rate (fraction)

= pressure of the specified device at inlet or outlet (" water or atm)

$=$ residence time of sorbent in device (hours)

$=$ temperature of specie for the specified device at inlet or outlet $\left({ }^{\circ} \mathrm{F}\right)$

$=$ total capital cost $(\$)$

$=$ total plant cost $(\$)$

$=$ total plant investment $(\$)$

$=$ total direct cost $(\$)$

$=$ total operating and maintenance cost, sum of FOC and VOC $(\$ / y r)$ 
$\mathrm{U}_{\text {device }}$

UC specie

Utspecie

VOC

$\mathrm{W}_{\mathrm{Na}}$

$\mathrm{X}$

$y_{\text {inlet or outlet }}$
$=$ universal heat transfer coefficient for device $\left(\mathrm{Btu} / \mathrm{hr}-\mathrm{ft}^{2}{ }^{\circ} \mathrm{F}\right)$

$=$ unit cost of specie (\$/unit)

= utilitization constant for species in regenerator (fraction)

= superficial velocity of flue gas through adsorber $(\mathrm{ft} / \mathrm{sec})$

= variable operating cost $(\$ / y r)$

= weight fraction of sodium to sorbent (fraction)

$=$ mean value of the fractional conversion of the sorbent in the entire adsorber (fraction)

$=$ molar fraction of $\mathrm{SO}_{2}$ in the flue gas (fraction)

\section{Greek Lettér Symbols}

$\delta_{\text {NOx }}=$ fraction of $\mathrm{NO}_{\mathrm{x}}$ returned to boiler which is destroyed (fraction)

$\Delta \mathrm{H}_{\text {device }} \quad=$ heat of reaction in device $(\mathrm{Btu} / \mathrm{hr})$

$\eta_{\text {specie,device }}=$ efficiency of device (fraction)

$\lambda$ $=$ molar stoichiometry of $\mathrm{SO}_{2}$ to active sorbent

$\rho_{\text {sorb }}$ $=$ bulk density of sorbent $\left(\mathrm{lbs} / \mathrm{ft}^{3}\right)$

Subscripts

$1=$ specifies the first part or half of a device

guess $=$ used to indicate the guess of a value in the interpolating algorithms

$\mathrm{i} \quad=$ stands for inlet

$\mathrm{j}, \mathrm{k}=$ used in sums to specify equipment or species.

$\mathrm{O} \quad=$ stands for outlet

std = emission standard for either $\mathrm{SO}_{\mathrm{x}}$ or $\mathrm{NO}_{\mathrm{x}}$

Species:

acid = sulfuric acid

air = air

ash $=$ ash

c = combustion air for gas bumer not including air needed to maintain maximum temperature

$\mathrm{CD}=$ carbon dioxide

$\mathrm{CM}$ = carbon monoxide

CS = carbon oxide sulfide, $\operatorname{COS}$

ex = excess air for the gas burner needed to maintain temperature

$\mathrm{H}=$ hydrogen, $\mathrm{H}_{2}$

$\mathrm{HS}$ = hydrogen sulfide, $\mathrm{H}_{2} \mathrm{~S}$

$\mathrm{M}=$ methane, $\mathrm{CH}_{4}$

makeup = makeup sorbent

$\mathrm{N} \quad=$ nitrogen, $\mathrm{N}_{2}$

$\mathrm{NO}=$ nitrogen oxide, $\mathrm{NO}$

$\mathrm{ND}=$ nitrogen dioxide, $\mathrm{NO}_{2}$

$\mathrm{O}=$ oxygen, $\mathrm{O}_{2}$

st $=$ stearn

sorb = sorbent

$S \quad=$ sulfur, $S_{2}$ 
$\mathrm{SC}=$ sulfur componinds, includes $\mathrm{COS}, \mathrm{H}_{2} \mathrm{~S}, \mathrm{~S}_{2}, \mathrm{SO}_{2}$, and $\mathrm{SO}_{3}$

$\mathrm{SD} \quad=$ sulfur dioxide, $\mathrm{SO}_{2}$

SOX = sulfur dicxide and sulfur trioxide

$\mathrm{ST} \quad=$ sulfur trioxide, $\mathrm{SO}_{3}$

$\mathrm{W}=$ water, $\mathrm{H}_{2} \mathrm{O}$

Equipment:

aph = air preheater

$\mathrm{AD}=$ adsorber

$\mathrm{AH} \quad=$ air heater for sorbent heater

$\mathrm{AP} \quad=$ acid plant

b = boiler in acid plant

$\mathrm{B} \quad=$ boiler of power plant

$\mathrm{BF}=$ dilution air blower and filtes

CS = catalytic converter contact section

D $\quad$ drying tower

ES = effluent strippers

$\mathrm{GB}=$ gas burner

GC = gas humidification and cooling tower

$\mathrm{HP}$ = heat recovery preheater

IC = inlet compressor

$\mathrm{MC}=$ main compressor

$\mathrm{PA}=$ product acid

$\mathrm{R} \quad$ = regenerator

$R \& S=$ regenerator and steam treatment vessel

S = superheater

$\mathrm{SC}=$ sorbent cooler

$\mathrm{SH}=$ sorbent heater

SS = strong acid handling systern

STV = steam treatment vessel

$\mathrm{T} \quad=$ interpass and final towers and associated equipment

WA $=$ weak acid system

Categories for capital and operating cost:
acid
$=$ acid plant
admin
= support and administration labor
credit
$=$ income from sale of sulfuric acid
eng
$=$ engineering and home office fees
gf
$=$ general facilities
inv = inventory capital
maint-labor = maintenance labor
maint-matl = maintenance material
makeup = makeup catalyst due to attrition loss
marketing = marketing and shipping charges for selling sulfuric acid
misc = royalty and land charges
oper = operating labor
proc $\quad=$ process contingency
proj $\quad=$ project contingency
startup = startup charges for one month
work = working capital 


\section{Introduction}

This is the third quarterly report of DOE Contract No. DE-AC22-87PC79864, entitled "Modeling of Integrated Environmental Control Systems for Coal-Fired Power Plants." This report summarizes accomplishments during the period April 1, 1988 to June 30, 1988. Our efforts during the last quarter focused on, (1) completion of a sulfuric acid plant model (used in conjunction with by-product recovery processes for $\mathrm{SO}_{2} / \mathrm{NO}_{\mathrm{x}}$ removal) and, (2) an update the NOXSO process model. Other accomplishments involved revision and expansion of the enthalpy data algorithms used for process energy balances. The sections below present the details of these developments. References are included at the end of each section.

\section{NOXSO Process Model}

The NOXSO process model incorporated in our integrated modeling framework was originally developed by Barrett [1]. The present NOXSO model is based on designs by NOXSO Corp. $[2,3,4,5]$, and Siearns-Rogers [6]. The design of the process has changed over time to incorporate potential improvements. The current process design for this model is based on a study for EPRI [6], with one modification suggested by NOXSO Corp [7], i.e., using methane as the reducing gas instead of synthesis gas produced from a Texaco Coal Gasification System.

The NOXSO process is intended to remove over 90 percent of the $\mathrm{SO}_{\mathrm{x}}$ and $\mathrm{NO}_{\mathrm{x}}$ from the flue gas of a coal-fired power plant. The pollutants are adsorbed onto a sodium coated alumina sorbent in a fluidized bed reactor. The sorbent is regenerated producing various sulfur compounds and $\mathrm{NO}_{\mathrm{x}}$. The $\mathrm{NO}_{\mathrm{x}}$ and some of the $\mathrm{SO}_{\mathrm{x}}$ are returned to the boiler, while the rest of the sulfur compounds are sent either to a sulfuric acid or Claus plant. The $\mathrm{NO}_{\mathrm{x}}$ returned to the boiler is expected to partially decompose into nitrogen leading to a steady-state $\mathrm{NO}_{\mathrm{x}}$ concentration.

A proposed process diagram is shown in Figure 2-1. There are four major mass flows in the NOXSO process: (1) the sorbent recirculation stream; (2) the regenerator off-gas sent to the acid plant; (3) the sorbent heater gas stream containing $\mathrm{NO}_{\mathrm{x}}$ and $\mathrm{SO}_{\mathrm{x}}$ returned to the boiler; and, (4) the combustion/flue gas stream. This process diagram differs from the one used for the initial model developed by Barrett [1] in the following ways: 
Figure 2-1: NOXSO Process Diagram

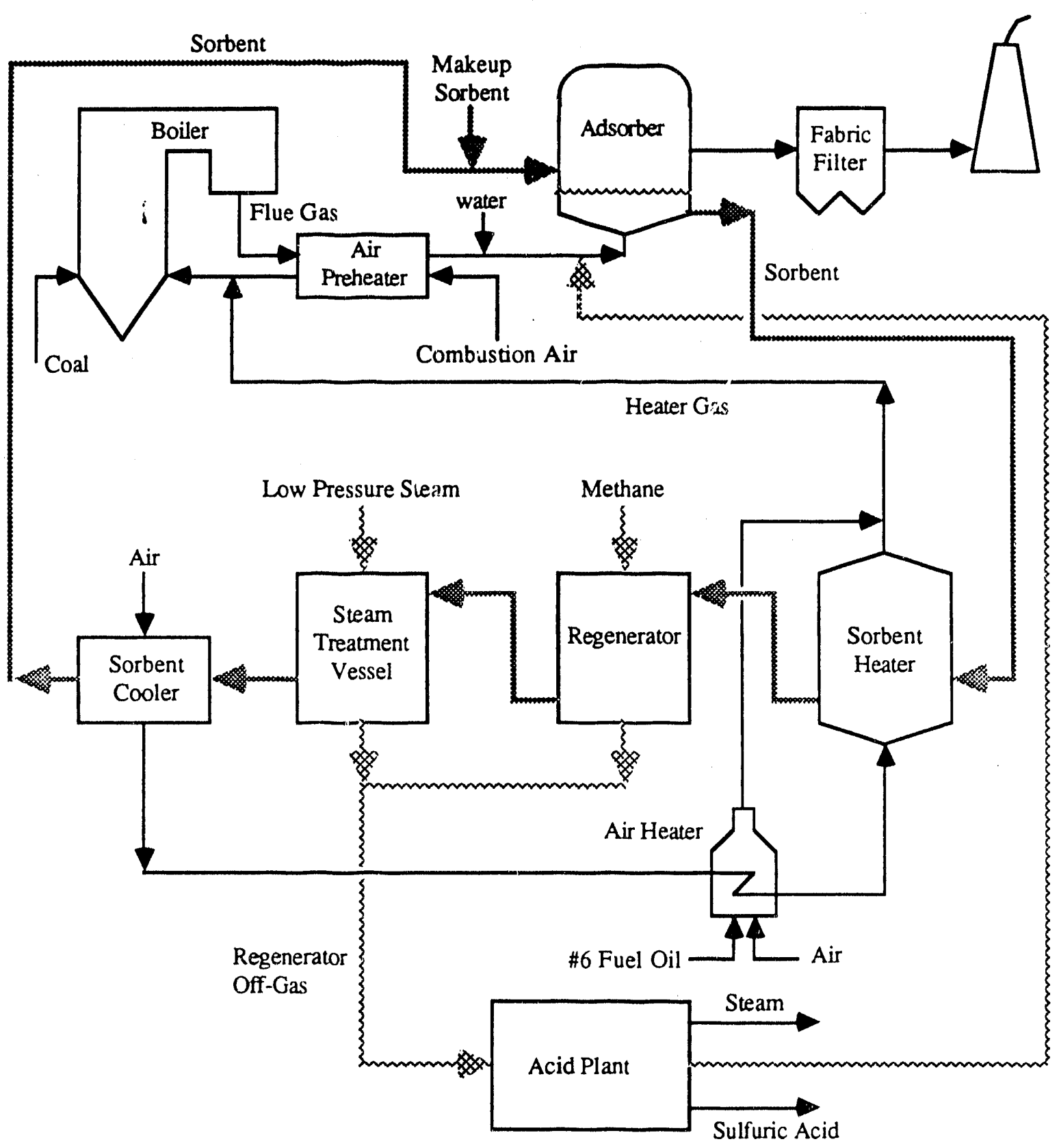


- oil is used instead of coal in the sorbent heater

- the cyclone in front of the adsorber has been removed

- methane is used for the reducing gas

- the adsorber by-pass option has been removed.

Figure $2-1$ is best examined by examining each major mass flow separately. The first mass flow to examine is the sorbent stream. The sorbent entering the adsorber contains some residual sulfur compounds. The sorbent removes $\mathrm{NO}_{\mathrm{x}}$ and $\mathrm{SO}_{\mathrm{x}}$ from the flue gas while raising the temperature of the flue gas. Then it enters the sorbent heater, where it releases all the $\mathrm{NO}_{\mathrm{x}}$ and about 8 to 10 percent of the $\mathrm{SO}_{\mathrm{x}}$ in the sorbent. The sorbent then enters the regenerator where methane (or some other reducing gas) is used to remove additional $\mathrm{SO}_{\mathrm{x}}$ in the sorbent. After the regenerator, the sorbent enters the steam treatment vessel where steam is used to removed most of the remaining sulfur compounds. Finally, the sorbent is cooled and makeup sorbent is added before it is returned to the adsorber.

The second major mass stream is the off gas from the regenerator. This gas stream is critical to the cost and performance of the acid plant, since its composition can drastically affect the cost of the sulfur recovery system. Its composition depends upon the type and quantity of reducing gas used and the design of the regenerator and steam treatment vessels. In the latest communications with NOXSO Corp. they have suggested that these two vessels be replaced with a single vessel.

The third major stream is the air stream used to heat and cool the sorbent and to return the $\mathrm{NO}_{\mathrm{X}}$ (and some $\mathrm{SO}_{\mathrm{X}}$ ) to the boiler. Recent tests have indicated that approximately $65 \%$ of the $\mathrm{NO}_{\mathrm{X}}$ returned to the boiler is decomposed [8]. This air stream also contains a significant amount of oxygen, so it is used to reduce the amount of combustion air entering the air preheater. This gas stream enters the sorbent cooler where it is heated by cooling the sorbent to approximately $210^{\circ} \mathrm{F}$. Then it enters the sorbent heater where it picks up the $\mathrm{NO}_{\mathbf{x}}$ and some $\mathrm{SO}_{\mathrm{x}}$. After leaving the sorbent heater it mixes with combustion air and enters the boiler.

The last mass flow is the combustion/flue gas stream. The inlet air passes through the air preheater and picks up the gas stream exiting the sorbent heater. This gas stream contains $\mathrm{NO}_{\mathrm{x}}$ and $\mathrm{SO}_{\mathrm{x}}$, as well as the products of combustion from the air heater, plus air used to heat and cool the sorbent. The inlet gas entering the air preheater is reduced in proportion to the amount of 
oxygen entering in this stream. The $\mathrm{SO}_{\mathbf{x}}$ comes from the sorbent heater and the combustion of \#6 fuel oil. This combined gas stream enters the boiler where some of the $\mathrm{NO}_{\mathrm{x}}$ decomposes. After the boiler it passes through the air preheater, where it picks up additional air leaking across air preheater. After the air preheater, the flue gas is cooled by adding water. It then enters the adsorber, where most of the $\mathrm{NO}_{\mathrm{x}}$ and $\mathrm{SO}_{\mathrm{x}}$ are removed by the sorbent. The cleaned flue gas picks up the attrition particles of the sorbent and enters the fabric filter. Here, particulate matter is removed before the gas is vented to the atmosphere.

The adsorption and regeneration chemistry of $\mathrm{NO}_{\mathrm{x}}$ and $\mathrm{SO}_{\mathrm{x}}$ are explained in detailed in many of the reports cited earlier, so only a brief summary will be given here. $\mathrm{SO}_{\mathrm{x}}$ is adsorbed onto both the sodium and alumina substrate and is dependent upon a number of parameters:

- Sorbent flow rate

- Available sodium on sorbent

- Oxygen content of flue gas

- $\mathrm{NO}_{\mathrm{x}}$ concentration

- Steam concentration

- Degree of dehydration on the sorbent surface

- Temperature of sorbent

The adsorption of $\mathrm{NO}_{\mathrm{X}}$ is dependant upon the temperatures and flow rates of sorbent, $\mathrm{SO}_{\mathrm{X}}$, steam, oxygen, and the type of reducing gas used. It has been found that increasing the temperature decreases $\mathrm{NO}_{\mathrm{x}}$ removal, while using methane for regeneration of $\mathrm{SO}_{2}$ improves the $\mathrm{NO}_{\mathrm{x}}$ removal efficiency.

The regeneration of $\mathrm{SO}_{\mathrm{x}}$ is a multi-step process. The first step is to heat the sorbent to approximately $1000^{\circ} \mathrm{F}$, where approximately $8-10 \%$ of the sulfur compounds and all the $\mathrm{NO}_{\mathrm{x}}$ are released. The next step is to treat the sorbent with a reducing gas, which releases $C O S, \mathrm{H}_{2} \mathrm{~S}, \mathrm{~S}_{2}$, and $\mathrm{SO}_{2}$, which are sent to the acid plant. Finally the sorbent is treated with steam to convert as many of the sulfites to $\mathrm{H}_{2} \mathrm{~S}$ as possible. $\mathrm{NO}_{\mathbf{x}}$ is regenerated by heating the sorbent to $1000^{\circ} \mathrm{F}$.

\subsection{Performance Model}

The primary purpose of the process performance model is to characterizes the major flow rates defined in the previous section and to predict the $\mathrm{NO}_{\mathrm{x}}$ and $\mathrm{SO}_{\mathrm{x}}$ removal efficiencies in the adsorber. The NOXSO process recycles some of the $\mathrm{NO}_{\mathbf{x}}$ and $\mathrm{SO}_{2}$ removed by the adsorber, 
which requires the adsorber to have a removal efficiency higher than the efficiency required by the emission standards. The recycled $\mathrm{SO}_{2}$ comes from the sorbent heater and the acid plant, while another source of $\mathrm{SO}_{2}$ is the air heater. The $\mathrm{NO}_{\mathrm{x}}$ and $\mathrm{SO}_{2}$ removal efficiencies are also linked. In the previous model, an equation was developed relating the $\mathrm{NO}_{\mathrm{x}}$ and $\mathrm{SO}_{2}$ removal efficiencies based on the adsorber temperature. For all the NOXSO designs proposed, the adsorber temperature has remained approximately the same, $250^{\circ} \mathrm{F}$. At this temperature the $\mathrm{NO}_{\mathrm{x}}$ and $\mathrm{SO}_{2}$ removal efficiencies are the same. Therefore, our current model assumes a bed temperature of $250^{\circ} \mathrm{F}$ with equal removal efficiencies for $\mathrm{SO}_{2}$ and $\mathrm{NO}_{\mathrm{x}}$.

The following procedure is then used to determined the sorbent flow rate:

- The required $\mathrm{SO}_{2}$ removal efficiency in the adsorber needed to meet the emission standard is determined which includes the effects of recycled $\mathrm{SO}_{2}$, and $\mathrm{SO}_{2}$ from the air heater.

- The required $\mathrm{NO}_{\mathrm{x}}$ removal efficiency in the adsorber needed to meet the emission standard is determined which includes the effects of recycled $\mathrm{NO}_{\mathbf{x}}$ and the $\mathrm{NO}_{\mathbf{x}}$ 'destroyed' in the boiler.

- The higher of the these removal efficiencies is used to determine the $\mathrm{NO}_{\mathrm{x}}$ and $\mathrm{SO}_{2}$ removed by the adsorber and the sorbent flow rate.

Figure 2-2 shows a simplified diagram of the flow of sulfur compounds through the NOXSO process. It should be noted that the steam treatment vessel and the regenerator have been lumped together, and that the sulfur dioxide from the air heater isn't shown. The sulfur dioxide from the air heater is dependant upon the sorbent flow rate, which depends upon the sulfur removal efficiency in the adsorber. Since this is an iterative problem, the approach taken was to first determine the removal efficiency in the adsorber without the addition of sulfur dioxide from the air heater. Then, the removal efficiency in the adsorber is increased by a small amount to account for the sulfur dioxide from the air heater. The following efficiencies are either known or assumed:

- $S O_{x}$ emission standard and removal efficiency, $\eta_{\text {std }}$

- fraction of sulfur retained in bottom ash, $\eta_{\text {ash }}$

- fraction of sulfur compounds not released in the sorbent heater, $\eta_{\mathrm{SH}}$

- fraction of sulfur compounds regenerated in the regenerator, $\eta_{R}$

- fraction of sulfur compounds regenerated in the steam treatment vessel, $\eta_{S T V}$

- fraction of sulfur compounds converted to sulfuric acid in acid plant, $\eta_{\mathrm{AP}}$ 
Figure 2-2: Simplified Diagram of Mass Flows for Sulfur Compounds

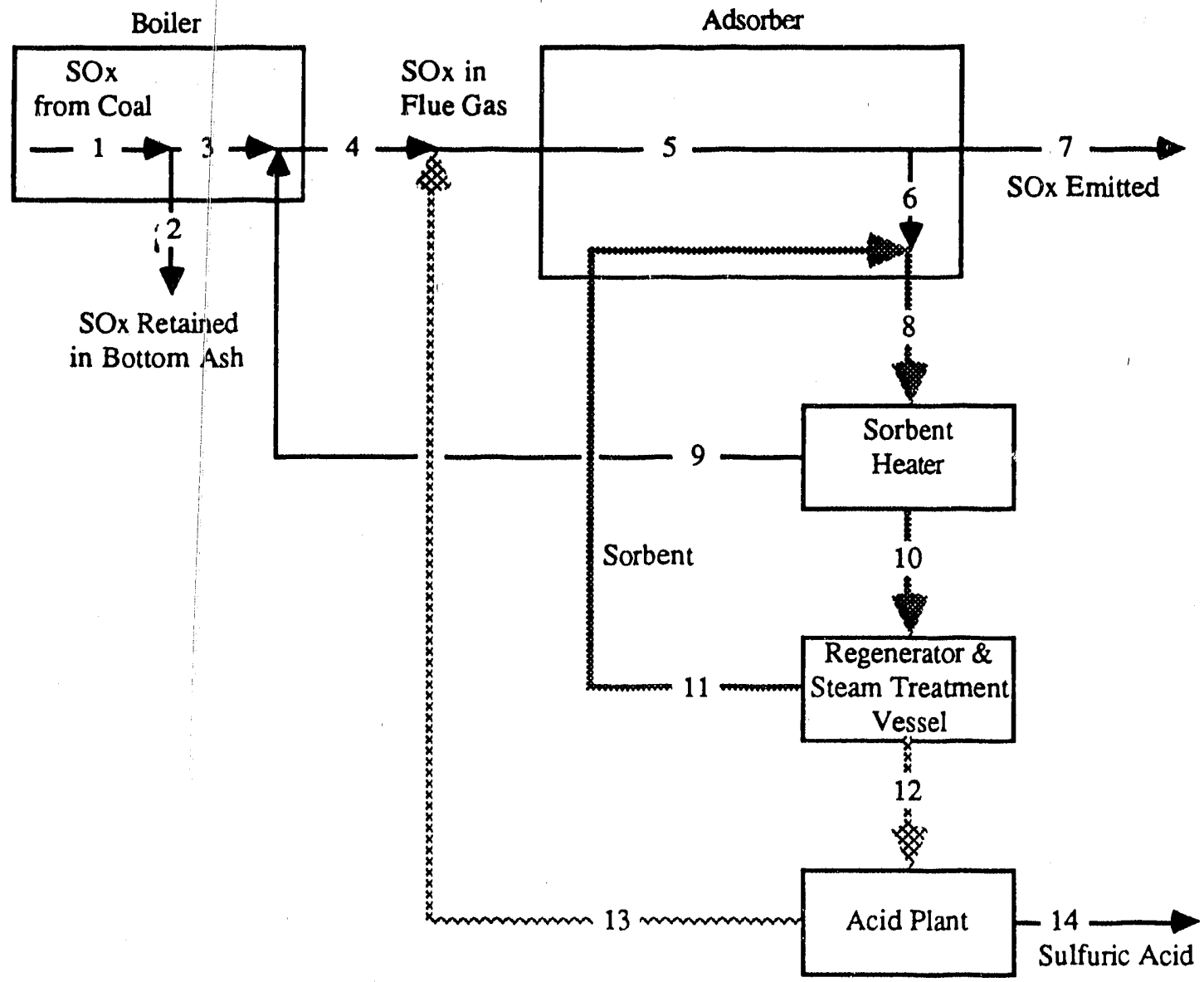

Figure 2-3: Simplified Diagram of Mass Flows for $\mathrm{NO}_{\mathrm{x}}$

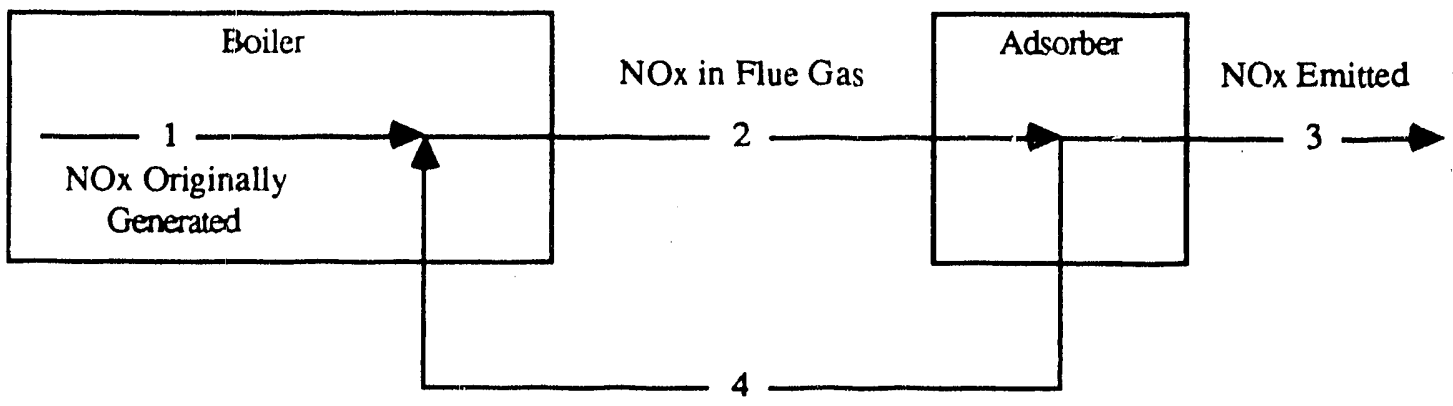

NOx Recyled to Boiler 
The objective is to derive the actual $\mathrm{SO}_{2}$ removal efficiency in the adsorber knowing the $\mathrm{SO}_{\mathrm{x}}$ in the flue gas from the coal, the removal efficiency required by the emission standard, and the efficiencies of the sorbent heater, regenerator, and the acid plant. It is assumed that none of the $\mathrm{SO}_{2}$ returned to the boiler from the sorbent heater is retained in the bottom ash. These conservation of mass equations (Equations 2.1) are needed to determine the apparent and actual $\mathrm{SO}_{\mathrm{x}}$ removal efficiencies in the adsorber:

$$
\begin{array}{ll}
M_{6}=M_{8}-M_{11} & M_{12}=\frac{M_{14}}{\eta_{A P}} \\
M_{8}=\frac{M_{10}}{\eta_{S H}} & M_{14}=\eta_{\text {std }} M_{3} \\
M_{11}=M_{10}\left(1-\eta_{R \& S}\right) & M_{5}=M_{6}+M_{7} \\
M_{10}=\frac{M_{12}}{\eta_{R \& S}} & M_{7}=M_{3}\left(1-\eta_{\text {std }}\right) \\
\text { where } \eta_{\text {R\&S }}=\eta_{R}+\left(1-\eta_{R}\right) \eta_{S T V} &
\end{array}
$$

The apparent removal efficiency is defined as the $\mathrm{SO}_{\mathrm{x}}$ removed by the adsorber, $\mathrm{M}_{6}$, divided by the $\mathrm{SO}_{\mathrm{x}}$ from the coal, $\mathrm{M}_{3}$. Substituting for $\mathrm{M}_{6}$ and simplifying yields Equation 2.2, which determines the apparent removal efficiency based on known values:

$$
\begin{aligned}
& \eta_{\text {app }}=\frac{M_{6}}{M_{3}}=\frac{M_{8}-M_{11}}{M_{3}}=\frac{\frac{M_{10}}{\eta_{S H}}-M_{10}\left(1-\eta_{R \& S}\right)}{M_{3}}=\frac{M_{10}\left(\eta_{R \& S}-1+\frac{1}{\eta_{S H}}\right)}{M_{3}} \\
& \eta_{\text {app }}=\frac{M_{12}\left(\eta_{R \& S}-1+\frac{1}{\eta_{S H}}\right)}{M_{3} \eta_{R \& S}}=\frac{M_{14}\left(\eta_{R \& S}-1+\frac{1}{\eta_{S H}}\right)}{M_{3} \eta_{R \& S} \eta_{A P}}=\frac{M_{3} \eta_{s t d}\left(\eta_{R \& S}-1+\frac{1}{\eta_{S H}}\right)}{M_{3} \eta_{R \& S} \eta_{S H}} \\
& \eta_{\text {app }}=\frac{\eta_{\text {std }}\left(h_{R \& S}-1+\frac{1}{\eta_{S H}}\right)}{\eta_{R \& S} \eta_{A P}}
\end{aligned}
$$

The actual $\mathrm{SO}_{2}$ removal efficiency in the adsorber is defined as the $\mathrm{SO}_{\mathrm{x}}$ removed, $\mathrm{M}_{6}$, divided by the $\mathrm{SO}_{\mathrm{x}}$ entering the adsorber, $\mathrm{M}_{5}$. Substituting $\eta_{\text {app }} \mathrm{M}_{3}$ for $\mathrm{M}_{6}$ and simplifying, yields the actual removal efficiency. This value is multiplied by a constant to account for the sulfur from the oil burned in the air heater.

$$
\eta_{\text {SOX }}=\frac{M_{6}}{M_{5}}=\frac{\eta_{\text {app }} M_{3}}{M_{6}+M_{7}}=\frac{\eta_{\text {app }} M_{3}}{\eta_{\text {app }} M_{3}+\left(1-\eta_{\text {std }}\right) M_{3}}=\frac{\eta_{\text {app }}\left(1+F_{\text {oil }}\right)}{\eta_{\text {app }}+1-\eta_{\text {std }}}
$$


The next step is to determine the $\mathrm{NO}_{\mathbf{x}}$ removal efficiency required by the emission standard (including the effects of recycling $\mathrm{NO}_{\mathrm{x}}$ to the boiler). Figure 2-3 shows a simplified $\mathrm{NO}_{\mathrm{x}}$ flow diagram. The following parameters are known: the $\mathrm{NO}_{\mathbf{x}}$ produced originally, $\mathrm{M}_{1}$; the emission constraint, $\mathrm{M}_{3}$; and the fraction of $\mathrm{NO}_{\mathbf{x}}$ "destroyed" in the boiler. The actual $\mathrm{NO}_{\mathbf{x}}$ removal efficiency is defined as the $\mathrm{NO}_{\mathrm{x}}$ removed, $\mathrm{M}_{4}$, divided by the $\mathrm{NO}_{\mathrm{x}}$ entering the adsorber, $\mathrm{M}_{2}$. Substituting for $\mathrm{M}_{4}$ and $\mathrm{M}_{2}$ and simplifying yields:

$$
\eta_{\mathrm{NOX}}=\frac{M_{4}}{M_{2}}=\frac{M_{4}}{M_{1}+\left(1-\delta_{\text {NOX }}\right) M_{4}}=\frac{\frac{\eta_{\text {NOX }} M_{3}}{1-\eta_{N O X}}}{M_{1}+\frac{\left(1-\delta_{N O X}\right) \eta_{N O X} M_{3}}{1-\eta_{\text {NOX }}}}=\frac{M_{1}-M_{3}}{M_{1}-\left(1-\delta_{N O X}\right) M_{3}}
$$

where,

$$
\mathrm{M}_{2}=\mathrm{M}_{1}+\left(1-\delta_{\mathrm{NOX}}\right) \mathrm{M}_{4} \quad \mathrm{M}_{4}=\frac{\eta_{\mathrm{NOX}} \mathrm{M}_{3}}{\left(1-\eta_{\mathrm{NOX}}\right)}
$$

Since the removal efficiencies for $\mathrm{NO}_{\mathbf{x}}$ and $\mathrm{SO}_{\mathbf{x}}$ are equal, the $\mathrm{SO}_{\mathbf{x}}$ removal efficiency for the adsorber equals the larger of the two values. NOXSO has reported that the actual $\mathrm{NO}_{\mathrm{x}}$ removal efficiency is based on the concentration of $\mathrm{SO}_{\mathbf{x}}[8]$. However, a steady state relationship between $\eta_{\mathrm{NOX}}$ and the concentration of $\mathrm{SO}_{\mathbf{x}}$ could not be determined from the available data.

$$
\text { if } \begin{aligned}
\eta_{\text {SOX }} & >\eta_{\text {NOX }} \text { then } \\
\eta_{\text {SOX }, A} & =\eta_{\text {SOX }}
\end{aligned}
$$

else

$$
\begin{aligned}
\eta_{\text {SOX,A }}=\eta_{\text {NOX }} \\
\eta_{\text {NOX,A }}=\eta_{\text {SOX,A }}
\end{aligned}
$$

With $\mathrm{NO}_{\mathbf{x}}$ removal efficiency determine, the amount of $\mathrm{NO}_{\mathbf{x}}$ removed by the adsorber and the $\mathrm{NO}_{\mathrm{X}}$ entering the adsorber can be determined with the following equations:

$$
\begin{aligned}
& M_{2}=M_{1}+\left(1-\delta_{\text {NOX }}\right) M_{4}=M_{1}+\left(1-\delta_{\text {NOX }}\right) \eta_{\text {NOX,A }} M_{2}=\frac{M_{1}}{1-\left(1-\delta_{\text {NOX }}\right) \eta_{\text {NOX,A }}} \\
& M_{4}=\eta_{\text {NOX,A }} M_{2}
\end{aligned}
$$

With the actual $\mathrm{SO}_{\mathbf{x}}$ removal efficiency in the adsorber known, it is possible to determine the $\mathrm{SO}_{\mathrm{x}}$ removed by the adsorber and the $\mathrm{SO}_{\mathrm{x}}$ remaining in the flue gas. The derivation of Equations 2.9 and 2.10 are quite involved and are not presented here. Equations 2.11 and 2.12 are easily derived from Figure 2-2. 


$$
\begin{aligned}
& \mathrm{C}=\left(1-\eta_{\mathrm{SOX}, \mathrm{A}}\right)\left(\frac{1-\eta_{\mathrm{SH}}}{h_{\mathrm{SH}} \eta_{\mathrm{R} S \mathrm{~S}}}+1\right) \\
& \mathrm{M}_{7}=\frac{\mathrm{CM}_{3}}{\mathrm{C}+\eta_{\mathrm{SOX}, \mathrm{A}} \eta_{\mathrm{AP}}} \\
& \mathrm{M}_{6}=\frac{\eta_{\mathrm{SOX}, \mathrm{A}} \mathrm{M}_{7}}{1-\eta_{\mathrm{SOX}, \mathrm{A}}} \\
& \mathrm{M}_{8}=\frac{\mathrm{M}_{6}}{1-\left(1-\eta_{\mathrm{R} \& \mathrm{~S}}\right) \eta_{\mathrm{SH}}}
\end{aligned}
$$

The sorbent flow rate is determined by an algorithm developed by NOXSO [8]. The numerator in Equation 2.13 is the $\mathrm{SO}_{\mathrm{x}}$ removed by the adsorber, $\mathrm{M}_{6} . \lambda$ is the ratio of available sodium to sulfur removed and is assumed to be unity [7]. The parameter $\mathrm{X}$ can be determined by existing algorithms [8].

$$
\begin{aligned}
& \mathrm{m}_{\text {sorb }}=\frac{A_{A} V C_{0}\left(y_{i}-y_{0}\right)}{\lambda N_{t} X}=\frac{M_{6}}{\lambda N_{t} X} \\
& X=\frac{\ln \left(\frac{y_{0}}{y_{i}}\right) V}{k_{a} P H}+1=\frac{\ln \left(1-\eta_{\text {SOX,A }}\right) V}{k_{a} P H}+1
\end{aligned}
$$

$H, K_{a}, P$, and $\lambda$ are input parameters. $K_{a}$ is currently set to 3.7 according to Ref. 8 , while $P$ is assumed to be 1 atmosphere. $N_{t}$ is the loading of active sorbent material to the weight of sorbent. This can be determined by the following equation:

$$
N_{t}=\frac{w_{N a}}{23 \eta_{R \& S}}
$$

Once the sorbent flow rate is known, the makeup sorbent rate and the energy required to pump the sorbent can be determined. The makeup sorbent rate is assumed to be a fraction of the sorbent rate, and is an input parameter. Energy to pump the sorbent is assumed to be proportional to the energy estimated in the EPRI report [6]:

$$
\begin{aligned}
& \mathrm{m}_{\text {makeup }}=\mathrm{f}_{\text {makeup }} \mathrm{m}_{\text {sorb }} \\
& \mathrm{EC}_{\text {sorb }}=1795 \mathrm{~kW} / 1.3486 \mathrm{e}^{6} \mathrm{lb} / \mathrm{hr} * \mathrm{~m}_{\text {sorb }}=1.32 \mathrm{e}^{-3} \mathrm{~m}_{\text {sorb }}
\end{aligned}
$$

The energy required to raise the sorbent temperature to $1110^{\circ} \mathrm{F}$ from the exit temperature of the adsorber is simply the difference in enthalpy times the sorbent flow rate. This determines the

$1 e^{\#}$ is used to signity " $x 10^{\#} . "$ 
amount of air needed by the sorbent heater. It is assumed that the air temperature drops from $1280^{\circ} \mathrm{F}$ to $610^{\circ} \mathrm{F}$ in the sorbent heater.

$$
\begin{aligned}
& E_{\text {sorb }, S H}=\left(\hat{h}_{\text {sorb }}(1110)-\hat{h}_{\text {sorb }}(250)\right) m_{\text {sorb }} \\
& M_{\text {air,SH }}=\frac{E_{\text {sorb, SH }}}{\hat{h}_{\text {air }}(1,280)-\hat{h}_{\text {air }}(610)}
\end{aligned}
$$

Once the flow rate of the air is determined, the amount of energy needed to heat the air to $1280^{\circ} \mathrm{F}$ is equal to the energy flow rate of air at $1280^{\circ} \mathrm{F}$ minus the heat given up in the sorbent cooler minus the energy flow rate of air at $100^{\circ} \mathrm{F}$, which is the temperature of the air after the compressor. The sorbent flow rate at the sorbent cooler is approximately $7 \%$ less than when it left the adsorber; it is also assumed to drop from $970^{\circ} \mathrm{F}$ to $210^{\circ} \mathrm{F}$.

The energy required to heat the air determines the oil requirement for the air heater. The efficiency of the air heater is an input parameter. The electricity consumption of the compressor is determined by the flow rate of air and the pressure increase, which is assumed to be $84^{\prime \prime}$ of water.

$$
\begin{aligned}
& \mathrm{E}_{\mathrm{air}, \mathrm{AH}}=\left[\left(\hat{\mathrm{h}}_{\mathrm{air}}(1280)-\hat{\mathrm{h}}_{\mathrm{air}}\left(10 \mathrm{C}_{;}\right)\right] \mathrm{M}_{\mathrm{air}, \mathrm{SH}}-0.93\left[\left(\hat{\mathrm{h}}_{\text {surb }}(979)-\hat{h}_{\text {i:orb }}(210)\right) \mathrm{m}_{\text {sorb }}\right.\right. \\
& \mathrm{EC}_{\mathrm{air}, \mathrm{SH}}=\left(\frac{1,545 \mathrm{M}_{\text {air,SH }}}{0.75 * 60 * 44,240}\right)\left(\frac{1.4}{1.4-1}\right)\left[\left(\frac{14.687+3.612 \mathrm{e}^{-2 * 84}}{14.687}\right)^{\frac{1.4-1}{1.4}}-1\right](80+460)
\end{aligned}
$$

Once the energy requireinent to heat the air is known, this determines the oil requirement for the air heater. The efficiency of the air heater is an input parameter, and $18 \%$ excess air is assumed. With the oil consumption known, the amount of combustion air for the air heater can be determined. The oil is assumed to be a heavy fuel oil, with a higher heating value of $18,400 \mathrm{Btu} / \mathrm{lb}$ and the following composition: $87.87 \%$ carbon, $10.33 \%$ hydrogen, $1.16 \%$ sulfur, $0.14 \%$ nitrogen, and $0.50 \%$ oxygen [9]. The actual composition is not extremely critical; however, all the components are in place in case another fuel, such as coal, is used.

$$
\begin{aligned}
& \mathrm{m}_{\text {oil }}=\frac{\mathrm{E}_{\mathrm{air}, \mathrm{SH}}}{\mathrm{HHV} \mathrm{oil}_{\mathrm{AH}}} \\
& \mathrm{m}_{\mathrm{air}, \mathrm{AH}}=\frac{\left(\frac{0.8787}{12}+\frac{0.1033}{4}+\frac{0.0116}{32}-\frac{0.005}{32}\right) 1.18 \mathrm{~m}_{\text {oil }}}{\mathrm{f}_{\mathrm{O}, \text { wet air }}}
\end{aligned}
$$


The amount of steam and methane used in the regenerator and steam treatment vessels can be calculated once the sulfur flow rate exiting the sorbent heater is found. The methane requirement for the regenerator is assumed to be proportional to the sulfur dioxide entering the regenerator. According to NOXSO, approximately 3690 SCFM of methane are needed for $575 \mathrm{lb}$-moles per hour of sulfur dioxide [10]. Also 3.34 moles of steam are needed for each mole of sulfur dioxide entering the stęam treatment vessel. The constant converting SCFM to $\mathrm{lb}$-moles/hr is 0.1585 assuming at standard temperature of $58^{\circ} \mathrm{F}$.

$$
\begin{aligned}
& M_{S C, R, i}=M_{S C, A, o} \eta_{S H} \\
& M_{M, R, i}=3690 / 575 * 0.1585 M_{S C, R, i} \\
& M_{W, S T V, i}=3.34\left(1-\eta_{S T V}\right) M_{S C, R, i}
\end{aligned}
$$

The utilization of methane and steam and the fractions of $\mathrm{SO}_{2}, \mathrm{H}_{2} \mathrm{~S}$, and $\mathrm{S}_{2}$ produced in the regenerator are input pararmeters. It is assumed that there is sufficient oxygen to convert all the carbon in the methane to $\mathrm{CO}_{2}$; that no $\mathrm{COS}$ is formed; and that all only $\mathrm{H}_{2} \mathrm{~S}$ and steam are produced in the steam treatment vessels. The moisture content of the regenerator gas is assumed to be the steam not utilized in the steam treatment vessel pius the hydrogen released when methane is converted to carbon dioxide minus the hydrogen used to form hydrogen sulfide. This gas is sent to either a sulfuric acid piant or an elemental suifur (Claus) plant.

$$
\begin{aligned}
& M_{M, R, O}=\left(1-\eta_{R}\right) M_{M, R, i} \\
& M_{S D, R, 0}=f p_{S D, R} \eta_{R} M_{S D, R, i} \\
& M_{H S, R, O}=\left(f p_{H S, R} \eta_{R}+\left(1-\eta_{R}\right) \eta_{S T V}\right) M_{S D, R, i} \\
& M_{S, R, O}=\left(1-f p_{S D, R}-f p_{H S, R}\right) \eta_{R} M_{S D, R, i} / 2 \\
& M_{M, R, O}=\left(1-U t_{M}\right) M_{M, R, i} \\
& M_{C D, R, O}=U t_{M} M_{M, R, i} \\
& M_{W, R, O}=\left(1-U t_{W}\right) M_{W, S T V, i}+2 M_{C D, R, O}-f p_{H S, R} \eta_{R} M_{S D, R, i}
\end{aligned}
$$

The next step is to determine the composition of the gas returned to the boiler. This gas stream consist of three other streams. The first is the air used to heat and cool the sorbent, $\mathrm{M}_{\mathrm{air}, \mathrm{SH}}$. The second is the $\mathrm{NO}_{\mathrm{x}}$ and $\mathrm{SO}_{\mathrm{x}}$ picked up by this stream in the sorbent heater. Finally, there is the flue gas from the air heater. The off gas from the acid plant is returned to the flue gas upstream of 
the adsorber; however, since it is a small stream, and to simplify the calculations, it is treated as $\mathrm{SO}_{2}$ returned to the boiler. It is assumed that only $\mathrm{SO}_{2}$ is returned to the boiler from the sorbent heater, acid plant, and air heater. The composition of $\mathrm{NO}_{\mathbf{x}}$ returned to the boiler is assumed to be in the same proportions as that generated in the boiler. The temperature of this gas stream is estimated to be $620^{\circ} \mathrm{F}[6]$.

$$
\begin{aligned}
& M_{N, B, i} \Rightarrow f_{N, \text { wet air }} M_{a i r, S H}+0.0014 / 28 M_{\text {oil }} \\
& \mathrm{M}_{\mathrm{O}, \mathrm{B}, \mathrm{i}}=\mathrm{f}_{\mathrm{O}, \text { wet air }}\left(\mathrm{M}_{\mathrm{air}, \mathrm{SH}^{+}} 0.18 / 1.18 \mathrm{M}_{\mathrm{air}, \mathrm{AH}}\right)
\end{aligned}
$$

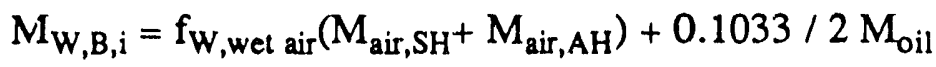

$$
\begin{aligned}
& \mathrm{M}_{\mathrm{CD}, \mathrm{B}, \mathrm{i}}=0.8787 / 12 \mathrm{M}_{\mathrm{oil}} \\
& \left.\mathrm{M}_{\mathrm{SD}, \mathrm{B}, \mathrm{i}}=\left[\left(1-\eta_{\mathrm{SH}}\right)+\left(1-\eta_{\mathrm{AP}}\right) \eta_{\mathrm{SH}} \eta_{\mathrm{R} \& S}\right)\right] \mathrm{M}_{\mathrm{SD}, \mathrm{A}, \mathrm{O}}+0.0116 / 32 \mathrm{M}_{\mathrm{oil}} \\
& \mathrm{M}_{\mathrm{NO}, \mathrm{B}, \mathrm{i}}=\mathrm{fp}_{\mathrm{NO}, \mathrm{B}} \mathrm{M}_{\mathrm{NOX}, \mathrm{A}, \mathrm{O}} \\
& \mathrm{M}_{\mathrm{ND}, \mathrm{B}, \mathrm{i}}=\left(1-\mathrm{fp}_{\mathrm{NO}, \mathrm{B}}\right) \mathrm{M}_{\mathrm{NOX}, \mathrm{A}, \mathrm{O}}
\end{aligned}
$$

Now the inlet combustion air and the composition of the flue gas exiting the boiler can be determined. The oxygen being returned to the boiler reduces the combustion air entering the air preheater. Since the nitrogen and moisture are based on the oxygen content, the only variable which needs to be modified is the oxygen required. See the analytical documentation for the IEC model [1]. Once these parameters are known, the composition of the flue gas exiting the boiler can be determined:

$$
\begin{aligned}
& M_{O, A P, i}=M_{O, \text { required }}-M_{O, B, i} \\
& \mathrm{M}_{\mathrm{CD}, \mathrm{B}, \mathrm{o}}=\mathrm{M}_{\mathrm{C}, \mathrm{coal}}+\mathrm{M}_{\mathrm{CD}, \mathrm{B}, \mathrm{i}} \\
& M_{W, B, o}=M_{W, \text { coal }}+M_{W, A P, i}+0.5 M_{H, \text { coal }}+M_{W, B, i} \\
& M_{S D, B, O}=f p_{S D, B} \eta_{a s h} M_{S, \text { coal }}+M_{S D, B, i} \\
& \mathrm{M}_{\mathrm{ST}, \mathrm{B}, \mathrm{O}}=\left(1-\mathrm{fp}_{\mathrm{SD}, \mathrm{B}}\right) \eta_{\mathrm{ash}} \mathrm{M}_{\mathrm{S}, \mathrm{coal}} \\
& \mathrm{M}_{\mathrm{ND}, \text { orig }}=\frac{\mathrm{NO}_{\mathrm{x}_{\mathrm{ef}} \mathrm{m}_{\mathrm{coal}}}}{46+\frac{30 \mathrm{fp}_{\mathrm{NO}, \mathrm{B}}}{1-\mathrm{fp}_{\mathrm{NO}, \mathrm{B}}}} \\
& M_{N O, \text { orig }}=\frac{\mathrm{fp}_{\mathrm{NO}, \mathrm{B}} \mathrm{M}_{\mathrm{ND}, \text { orig }}}{1-\mathrm{fp}_{\mathrm{NO}, \mathrm{B}}}
\end{aligned}
$$




$$
\begin{aligned}
\mathrm{M}_{\mathrm{ND}, \mathrm{B}, \mathrm{O}} & =\mathrm{M}_{\mathrm{ND}, \text { orig }}+\left(1-\delta_{\mathrm{NOX}}\right) \mathrm{M}_{\mathrm{ND}, \mathrm{B}, \mathrm{i}} \\
\mathrm{M}_{\mathrm{NO}, \mathrm{B}, \mathrm{O}} & =\mathrm{M}_{\mathrm{NO}, \text { orig }}+\left(1-\delta_{\mathrm{NOX}}\right) \mathrm{M}_{\mathrm{NO}, \mathrm{B}, \mathrm{i}} \\
\mathrm{M}_{\mathrm{N}, \mathrm{B}, \mathrm{O}}= & 0.5 \mathrm{M}_{\mathrm{N}, \text { coal }}+\mathrm{M}_{\mathrm{N}, \mathrm{AP}, \mathrm{i}}-0.5\left(\mathrm{M}_{\mathrm{NO}, \text { orig }}+\mathrm{M}_{\mathrm{ND}, \text { orig }}\right)+\mathrm{M}_{\mathrm{N}, \mathrm{B}, \mathrm{i}}+0.5 \mathrm{M}_{\mathrm{NOX}, \mathrm{A}, \mathrm{O}} \\
\mathrm{M}_{\mathrm{O}, \mathrm{B}, \mathrm{O}}= & \mathrm{M}_{\mathrm{O}, \mathrm{AP}, \mathrm{i}}+0.5 \mathrm{M}_{\mathrm{O}, \text { coal }}-2 \mathrm{M}_{\mathrm{C}, \mathrm{coal}}-0.25 \mathrm{M}_{\mathrm{H}, \mathrm{coal}}-\mathrm{fp}_{\mathrm{SD}, \mathrm{B}} \eta_{\mathrm{ash}} \mathrm{M}_{\mathrm{S}, \mathrm{coal}}-1.5 \mathrm{M}_{\mathrm{ST}, \mathrm{B}, \mathrm{o}} \\
& -0.5 \mathrm{M}_{\mathrm{NO}, \text { orig }}-\mathrm{M}_{\mathrm{ND}, \mathrm{orig}}+\mathrm{M}_{\mathrm{O}, \mathrm{B}, \mathrm{i}}+\delta_{\mathrm{NOX}}\left(\mathrm{M}_{\mathrm{ND}, \mathrm{B}, \mathrm{i}}+0.5 \mathrm{M}_{\mathrm{NO}, \mathrm{B}, \mathrm{i}}\right)
\end{aligned}
$$

With the flue gas flow rate and combustion air determined, the air preheater model can be used to determine the flue gas temperature leaving the air preheater, $\mathrm{T}_{\mathrm{fg}, \mathrm{AP}, \mathrm{o}}$, and the temperature of the combustion exiting the air preheater, $T_{a i r, A P, o}$. Now the amount of water added to cool the flue gas to $210^{\circ} \mathrm{F}$ and the volumetric flow rate into the adsorber can be determined. The water needed to cool the flue gas is the energy loss of the flue gas between the exit temperature of the air preheater and $210^{\circ} \mathrm{F}$ divided by 20,204 (the energy needed to raise a mole of water from $60^{\circ} \mathrm{F}$ to $212^{\circ} \mathrm{F}$ saturated steam). Now the gas flow rate into and exiting the adsorber can be determined:

$$
\begin{aligned}
& \mathrm{M}_{\mathrm{W}, \mathrm{fg}, \text { added }}=\frac{\sum_{\mathrm{i}=1}^{8}\left(\hat{\mathrm{h}}_{\mathrm{i}}\left(\mathrm{T}_{\mathrm{fg}, \mathrm{AP}, \mathrm{o}}\right)-\hat{\mathrm{h}}_{\mathrm{i}}(210)\right) \mathrm{M}_{\mathrm{i}, \mathrm{fg}}}{2.0,204} \\
& \mathrm{G}_{\mathrm{A}, \mathrm{i}}=\frac{\left(\sum_{\mathrm{i}=1}^{8} \mathrm{M}_{\mathrm{i}, \mathrm{fg}}+\mathrm{M}_{\mathrm{W}, \mathrm{fg}, \text { added }}\right) 1,545 *(210+460)}{14.687 * 144 * 60} \\
& \mathrm{G}_{\mathrm{A}, \mathrm{o}}=\mathrm{G}_{\mathrm{A}, \mathrm{i}} \frac{250+460}{210+460}
\end{aligned}
$$

With the volumetric flow rate determined, the number of operating train and the size of each adsorber can be determined. Each adsorber in EPRI renort handled 450,000 acfm [6]. The algorithm to determine the number of redundant trains is retained from Ref.[1]. The electricity consumption is required to overcome the pressure drop, in the adsorber (22" water) and to power the blower for the air heater. This blower is assumed to have a 4 " water pressure drop.

$$
\begin{aligned}
& \text { NOP }=\operatorname{round}\left(\frac{G_{A, i}}{450,000}\right) \\
& N R D=1+\text { if }\left(\frac{N O P}{4}-1\right)>1 \text { then round }\left(\frac{N O P}{4}-0.5\right)-1 \text { else } 0
\end{aligned}
$$




$$
\begin{aligned}
& \mathrm{A}_{\mathrm{A}}=\frac{\mathrm{G}_{\mathrm{A}, \mathrm{i}}}{60 \mathrm{NOP} \mathrm{V}} \\
& \mathrm{EC}_{\mathrm{FG}}=1.38 \mathrm{e}^{-4} * 22 \mathrm{G}_{\mathrm{A}, \mathrm{O}} \\
& \mathrm{EC}_{\mathrm{AH}}=\frac{1,545(80+460) \mathrm{M}_{\mathrm{AH}} * 4 * 1.38 \mathrm{e}^{-4}}{14.687 * 144 * 60}
\end{aligned}
$$

The NOXSO process consumes low pressure steam in the steam treatment vessel, while the acid plant may produce steam. Therefore, the net steam consumption or credit is the difference between the steam consumed by NOXSO and that generated by the acid plant. The temperature of the steam from the acid plant is set to $665^{\circ} \mathrm{F}$, the temperature of the steam required for the NOXSO process. Then, $15,940 \mathrm{Btu}$ is the energy required to raise a mole of saturated water at $226^{\circ} \mathrm{F}$ to saturated steam at $338^{\circ} \mathrm{F}$ minus the value from the enthalpy algorithms at $338^{\circ} \mathrm{F}$. The boiler is assumed to be $88 \%$ efficient. Therefore, the total power consumption of the NOXSO and acid plant is the sum of the requirements for the pressure drop in the flue gas, transport of the sorbent, compressor for the sorbent cooler, blower for the air heater, the acid plant, and (if required) the steam consumption:

$$
\begin{aligned}
& \mathrm{EC}_{\text {steam }}=\left(\mathrm{M}_{\mathrm{W}, \mathrm{STV}}-\mathrm{M}_{\text {steam }, \mathrm{AP}}\right) \frac{\hat{\mathrm{h}}_{\mathrm{W}}\left(665^{\circ} \mathrm{F}\right)+15,940}{0.88^{*} \mathrm{HR}} \\
& \mathrm{EC}_{\text {total }}=\mathrm{EC}_{\mathrm{fg}}+\mathrm{EC}_{\mathrm{air}, \mathrm{SC}}+\mathrm{EC}_{\mathrm{AH}}+\mathrm{EC}_{\text {sorb }}+\mathrm{EC}_{\mathrm{AP}}+\text { if } \mathrm{EC}_{\text {steam }}>0
\end{aligned}
$$

The energy is added to the power plant from the steam generated by the acid plant and the air recycled to the boiler. The electrical equivalent for the steam is straight forward. The energy credit for the air recycled to the boiler is more complicated, since it also reduces the amount of inlet combustion air and changes the performance of the air preheater. The energy credit for the recycled air is the energy flow rate of the recycled air plus inlet combustion air at the new air preheater exit temperature minus the energy flow rate of the original combustion air at $515^{\circ} \mathrm{F}$. The original combustion air is defined as the air required for the coal consumed.

$$
\begin{aligned}
& \mathrm{ECr}_{\text {recycled }}=\left(\mathrm{M}_{\text {recycled }} \hat{\mathrm{h}}(620)+\mathrm{M}_{\text {comb, air }} \hat{\mathrm{h}}\left(\mathrm{T}_{\mathrm{AP}, \mathrm{O}}\right)-\mathrm{M}_{\text {comb, air }} \hat{\mathrm{h}}(515)\right) / \mathrm{HR} \\
& \text { if } \mathrm{EC}_{\text {steam }}<0 \text { then } \mathrm{ECr}_{\text {steam }}=-\mathrm{EC}_{\text {steam }} \text { else } 0 \\
& \mathrm{ECr}_{\text {total }}=\mathrm{ECr}_{\text {recycled }}+\mathrm{EC}_{\text {steam }}
\end{aligned}
$$




\subsection{Economic Model}

The current economics model for the NOXSO process is based primarily on the recent case study by EPRI [6]. The major difference is that methane is used for the regeneration step rather than a synthesis gas produced on-site.

The capital costs are scaled to five key parameters: flue gas flow rate, sorbent flow rate, makeup flow rate, area of the adsorbers, and oil consumption. The values of these parameters for the EPRI base case plant (1000MW, $4 \% \mathrm{~S}$ coal) are: $3.6 \mathrm{e}^{6} \mathrm{acfm}, 1.36 \mathrm{e}^{6} \mathrm{lb} / \mathrm{hr}, 880 \mathrm{lb} / \mathrm{hr}, 2542$ $\mathrm{ft}^{2}$, and $7200 \mathrm{lb} / \mathrm{hr}$. The area of the adsorber, $2545 \mathrm{ft}^{2}$, is estimated from the gas flow rate into the adsorber, the number of operating trains, and the gas velocity through the adsorber. The capital cost for a larger air preheater, if that option it chosen, is also included as a part of the capital cost for the NOXSO process.

\subsubsection{Capital Costs}

The EPRI report lists plant components by section with delivered equipment costs itemized. The report also gives the total cost of each plant area. The cost of the components can be summed and divided into the total cost to determine a multiplier for each area. The total equipment cost, total process capital, and the appropriate multiplier are given in Table 2-1. Note that the design plant size is two $500 \mathrm{MW}$ units. The regeneration system, area 40 , contains a Texaco Coal Gasification System for producing regeneration gas. This item has been removed from the total listed in area 40 of Table 2-1. It was assumed to have a multiplier of one, since it is a delivered system. The sulfuric acid plant, particulate removal, and waste disposal areas are not listed since they have been explicitly modeled elsewhere in the IEC model.

The capital cost coefficients for each of the major parameters are estimated by adding all the component costs associated with each parameter, then divide through by the base value of the parameter (from the EPRI report) raised to the 0.7 power. The makeup rate of sorbent and oil consumption are used to scale the reagent feed system. Since the Texaco Coal Gasification System is not used, liquid oxygen storage is not needed. Miscellaneous process equipment is included in the coefficient for oil. Therefore the total capital cost for area 10 is:

$$
\mathrm{DCC}_{10}=\frac{1,651,777}{880^{0.7}} \mathrm{~m}_{\text {makeup }}^{0.7}+\frac{965,006}{7200^{0.7}} \mathrm{~m}_{\text {oil }}^{0.7}=14,350 \mathrm{~m}_{\text {makeup }}^{0.7}+1.925 \mathrm{~m}_{\text {oil }}^{0.7}
$$


Table 2-1: Area Cost Multipliers for NOXSO Process

\begin{tabular}{llccc}
\hline & & Equipment & Total & \\
Area & Description & Costs & $\frac{\text { Cost }}{5.57}$ & Multiplier \\
20 & Reagent Feed System & 12.76 & 2.29 \\
20 & $\mathrm{SO}_{2}$ Removal System & 7.52 & 2.52 & 2.99 \\
30 & Flue Gas Handling System & 27.00 & 13.65 & 1.98 \\
40 & Sorbent Regeneration System & 15.66 & 9.99 & $1.57 \mathrm{a}$ \\
70 & General Support Equipment & 0.30 & 0.17 & 1.77 \\
\hline
\end{tabular}

a Does not include the Texaco Coal Gasification System.

The capital cost for the flue gas equipment is broken into two components. The first component is area 30 , with a slight modification to the capital cost for the I.D. fans. Since the adsorber does not cause the entire pressure drop across the I.D. fans, it is only charged for its portion of the pressure drop, 22" water. Since the I.D. fans is sized for $30^{\prime \prime}$ of water, the NOXSO process is charged for $73 \%$ of the I.D. fans and dampers. The capital cost for the ductwork associated with the mu! lones and ESP are not included. The second component is the adsorber, which is in the $\mathrm{SO}_{2}$ removal system in the EPRI report. However, its cost is related to the flue gas flow rate, so it is included with the flue gas handling system. Thus:

$$
\begin{aligned}
& \mathrm{DCC}_{30}=\frac{20,599,176}{3,600,000^{0.7}} \mathrm{G}_{\mathrm{A}, \mathrm{i}}^{0.7}+\frac{5,292,001}{10 * 2,542^{0.7}}(\mathrm{NOP}+\mathrm{NRD}) \mathrm{A}_{\mathrm{A}}^{0.7} \\
& \mathrm{DCC}_{30}=530 \mathrm{G}_{\mathrm{A}, \mathrm{i}}^{0.7}+2,188(\mathrm{NOP}+\mathrm{NRD}) \mathrm{A}_{\mathrm{A}}^{0.7}
\end{aligned}
$$

The capital cost asscciated with the sorbent flow rate includes part of area 20 and most of area 40. The Texaco Coal Gasification System, regenerative gas burner, and the acid plant compressor are not included. The regenerative gas burner and acid plant compressor are part of the acid plant model. The equipment from area 20 is the regenerated sorbent transfer hopper and the pneumatic conveying system. The capital cost associated with general support equipment is taken as a fraction of the previous capital cost areas. The results are:

$$
\mathrm{DCC}_{40}=\frac{15,132,844}{1,358,600^{0.7}} \mathrm{~m}_{\text {sorb }}^{0.7}=770 \mathrm{~m}_{\text {sorb }}^{0.7}
$$




$$
\begin{aligned}
& \mathrm{DCC}_{70}=\frac{296,121}{43,640,804}\left(\mathrm{DCC}_{10}+\mathrm{DCC}_{30}+\mathrm{DCC}_{40}\right) \\
& \mathrm{DCC}_{70}=0.007\left(\mathrm{DCC}_{10}+\mathrm{DCC}_{30}+\mathrm{DCC}_{40}\right)
\end{aligned}
$$

The total direct capital cost is the sum of Equations 2.65 througn 2.68, plus the cost of a larger air preheater (if needed). The indirect capital charges include general facilities, engineering fees, project and project contingencies. These are assumed to be $10 \%, 12.5 \%, 21.2 \%$, and $13.4 \%$ respectively, of the total direct capital cost. The total plant cost is the sum of the following items, plus the total capital cost of the acid plant.

$$
\begin{aligned}
& \mathrm{DCC}_{\text {total }}=\mathrm{DCC}_{10}+\mathrm{DCC}_{30}+\mathrm{DCC}_{40}+\mathrm{DCC}_{70}+\mathrm{DCC}_{\mathrm{APH}} \\
& \mathrm{DCC}_{\mathrm{gf}}=0.10 \mathrm{DCC}_{\text {total }} \\
& \mathrm{DCC}_{\text {eng }}=0.125 \mathrm{DCC}_{\text {total }} \\
& \mathrm{DCC}_{\text {proj }}=0.212 \mathrm{DCC}_{\text {total }} \\
& \mathrm{DCC}_{\text {proc }}=0.134 \mathrm{DCC}_{\text {total }} \\
& \mathrm{TPC}=\mathrm{DCC}_{\text {total }}+\mathrm{DCC}_{\mathrm{gf}}+\mathrm{DCC}_{\mathrm{eng}}+\mathrm{DCC}_{\text {proj }}+\mathrm{DCC}_{\text {proc }}+\mathrm{TCC}_{\text {acid }}
\end{aligned}
$$

The cost of interest during construction is a function of the interest and inflation rates, and is taken as a fraction of the total plant cost. The project is assumed to take chree years to complete, with an equal amount of money spent each year. All funds are expended in the middle of each year. The interest rate is a function of the debt/equity ratio and is calculated according to EPRI guidelines [11]. The startup charges are estimated to be one month of the fixed and variable operating costs plus $2 \%$ of the total plant inventory cost. The royalty charges are assumed to be $0.5 \%$ of the total direct capital cost. The land costs are scaled to the size of the gross size of the plant. In sum:

$$
\begin{aligned}
& \mathrm{TPI}=\left(\left(\frac{1+\mathrm{i}}{1+\mathrm{p}}\right)^{0.5}+\left(\frac{1+\mathrm{i}}{1+\mathrm{p}}\right)^{1.5}+\left(\frac{1+\mathrm{i}}{1+\mathrm{p}}\right)^{2.5}\right) \frac{\mathrm{TPC}}{3} \\
& \mathrm{C}_{\text {startup }}=(\mathrm{FOC}+\mathrm{VOC}) / 12+0.02 \mathrm{TPI} \\
& \mathrm{C}_{\text {misc }}=0.005 \mathrm{DCC}_{\text {total }}+4.97 \mathrm{e}^{-5} \mathrm{MW}_{\mathrm{g}}
\end{aligned}
$$

Working capital is estimated as 60 days of consumption at full capacity for the makeup sorbent, methane, and oil. The sorbent cost is $\$ 2.5 / \mathrm{lb}$; the cost of oil is expressed in $\$$ per Btu, while 0.378 converts $\mathrm{lb}$-moles/hr to MSCF. 


$$
\mathrm{C}_{\text {work }}=\left(2.5 \mathrm{~m}_{\text {makeup }}+0.378 \mathrm{UC}_{\mathrm{M}} \mathrm{M}_{\mathrm{M}, \mathrm{R}, \mathrm{i}}+\mathrm{UC}_{\text {oil }} \mathrm{HHV}_{\mathrm{oil}} \mathrm{m}_{\text {oil }}\right) 24 * 60
$$

The inventory capital cost of the sorbent is estimated from the mass of sorbent in the process equipment. The settled bed height is estimated to be one-half of the expanded bed height. The amount of sorbent in the adsorber is estimated from the area of the adsorber, settled bed height, and density. The amount of sorbent in the rest of the system is estimated from the residence times of equipment and the mass flow rate of sorbent. The total capital cost is the sum of the total plant inventory, startup charges, working capital, inventory cost, land and royalty fees:

$$
\begin{aligned}
& \mathrm{C}_{\text {inv }}=\left(\frac{\mathrm{H}}{2} \mathrm{~A}_{\mathrm{A}} \rho_{\text {sorb }}+\frac{\mathrm{m}_{\text {sorb }}}{\mathrm{NOP}}\left(\mathrm{RT}_{\mathrm{R}}+\mathrm{RT}_{\mathrm{SH}}+\mathrm{RT}_{\mathrm{SC}}\right)\right)(\mathrm{NOP}+\mathrm{NRD}) * 2.5 \\
& \mathrm{TCC}=\mathrm{TPI}+\mathrm{C}_{\text {startup }}+\mathrm{C}_{\text {work }}+\mathrm{C}_{\text {inv }}+\mathrm{C}_{\text {misc }}
\end{aligned}
$$

\subsubsection{Operating and Maintenance Costs}

Annual operating charges consist of fixed and variables charges. The fixed charges consist of the operating, maintenance, administrative labor, and the maintenance materials. It is estimated that 5.2 workers per hour at $\$ 19.70 / \mathrm{hr}$ are needed for operating labor. Maintenance labor and materials and administration labor charges are estimated using the EPRI guidelines [11]. Maintenance cost is $4.8 \%$ of the total plant cost excluding the total capital cost for the acid plant. Labor accounts for $40 \%$, while materials account for $60 \%$ of the total maintenance cost. Administrative and support labor is estimated to be $30 \%$ of the operating and maintenance labor. The variable charges include the costs for makeup sorbent, methane, oil, and miscellaneous charges. The result is:

$$
\begin{aligned}
& \mathrm{OC}_{\text {oper }}=5.2 * 19.7 * 8766 \\
& \mathrm{OC}_{\text {maint-labor }}=0.40 * 0.048\left(\mathrm{TPC}-\mathrm{TCC}_{\mathrm{acid}}\right) \\
& \mathrm{OC}_{\text {maint-matl }}=0.60 * 0.048\left(\mathrm{TPC}-\mathrm{TCC}_{\mathrm{acid}}\right) \\
& \mathrm{OC}_{\text {admin }}=0.30\left(\mathrm{OC}_{\mathrm{oper}}+\mathrm{OC}_{\text {maint-labor }}\right) \\
& \mathrm{FOC}=\mathrm{OC}_{\mathrm{oper}}+\mathrm{OC}_{\text {maint-labor }}+\mathrm{OC}_{\text {maint-matl }}+\mathrm{OC}_{\mathrm{admin}} \\
& \mathrm{OC}_{\text {sorb }}=2.5 * 8,766 \mathrm{CF} \mathrm{m}_{\text {makeup }} \\
& \mathrm{OC}_{\mathrm{M}}=0.378 * 8,766 \mathrm{CF} \mathrm{UC}_{\mathrm{M}} \mathrm{M}_{\mathrm{M}, \mathrm{R}, \mathrm{i}} \\
& \mathrm{OC}_{\text {oil }}=8,766 \mathrm{CF} \mathrm{HHV} \text { oil } \mathrm{UC}_{\text {oil }} \mathrm{m}_{\text {oil }} \\
& \mathrm{OC}_{\text {misc }}=0.019 \mathrm{DCC} \mathrm{Lotal}
\end{aligned}
$$




$$
\text { 'VOC }=O C_{\text {sorb }}+O C_{M}+O C_{\text {oil }}+O C_{\text {misc }}
$$

The NOXSO process typically produces an energy credit. In the IEC model, energy credits are account for by increasing the output of the power plant while keeping coal consumption the same. The capital and operating costs. including the additional energy cost, of the increased size are charged to the basic power plant while the NOXSO process is given a credit for the energy it supplies to the power plant. This is equivalent to assuming that the NOXSO process decreases the amount of coal burned in the boiler. Since the energy credit and the cost of the NOXSO are dependent upon the coal consumption, it becomes an iterative problem.

$$
\begin{aligned}
& \mathrm{TCC}_{\mathrm{BP}, \text { incre }}=\frac{\mathrm{ECr}_{\text {total }}}{\mathrm{MWg} 1000} \mathrm{TCC}_{\mathrm{BP}} \\
& \mathrm{TVC}_{\mathrm{BP} \text {,incre }}=\frac{\mathrm{ECr}_{\text {total }}}{\mathrm{MWg} \mathrm{TVC}_{\mathrm{BP}}} \mathrm{TV00}^{*} \mathrm{OCr}_{\text {coal }}=8766 \mathrm{CF} \mathrm{UC} \mathrm{CCal}_{\text {coal }} \frac{\mathrm{ECr}_{\text {total }} \mathrm{HR}}{2000 \mathrm{HHV} \mathrm{V}_{\text {coal }}}
\end{aligned}
$$

The total capital and operating cost of the power plant are increased by $\mathrm{TCC}_{\mathrm{BP} \text {,incr }}+$ $\mathrm{TVC}_{\mathrm{BP} \text {,incr. }}$ The total variable cost of the NOXSO process is the sum of the fixed and variable operating costs minus the credits for ccal and the sale of sulfuric acid. Utility consumption is charged separately. The result is:

$$
\begin{aligned}
& \text { TVC }=\mathrm{FOC}+\text { VOC }-\mathrm{OCr}_{\text {coal }}-\mathrm{OC}_{\text {credit,acid }} \\
& \text { Util }=8766 \mathrm{CF} \mathrm{UC}_{\text {elec }} \mathrm{EC}_{\text {total }}
\end{aligned}
$$




\subsection{References}

1. Rubin, E.S., J.S. Salmento, J.G. Barrett, C.N. Bloyd, H.C. Frey. Modeling and Assessment of Advanced Processes for Integrated Environmental Control of Coal-Fired Power Plants. Final Report of Contract No. DE-FG22-83PC60271 from Carnegie Mellon University, Pittsburgh, PA to U.S. Department of Energy, Pittsburgh, PA, July, 1986. NTIS No. DE86014712/WEP, Springfield, VA.

2. Science Applications, Inc. Appendix A: Economic Evaluation of the NOXSO Process for Control of Coal Fired Flue Gas $\mathrm{NO}_{x}$ and $\mathrm{SO}_{x}$. Report of Contract No. DE-AC01-82FE61048(1) from NOXSO Corporation to the U.S. Department of Energy, Pittsburgh, PA, July, 1983.

3. Halsbeck, J.L., L.G. Neal, H.P. Tseng. Evaluation of the NOXSO Combined $\mathrm{NO}_{x} / \mathrm{SO}_{2}$ Flue Gas Treatment Process. Report of Contract No. DE-AC22-FE60148 from NOXSO Corporation to the U.S. Department of Energy, Pittsburgh, PA, September, 1983.

4. Halsbeck, J.L., C.J. Wang, L.G. Neal, H.P. Tseng, J.D. Tucker. Evaluation of the NOXSO Combined $\mathrm{NO}_{x} / \mathrm{SO}_{2}$ Flue Gas Treatment Process. Report of Contract No. DE-AC22FE60148 from NOXSO Corporation to the U.S. Department of Energy, Pittsburgh, PA, November, 1984

5. Halsbeck, J.L., C.J. Wang, L.G. Neal, C.P. Perng. Evaluation of the NOXSO Combined $\mathrm{NO}_{x} / \mathrm{SO}_{2}$ Flue Gus Treatment Process. Report of Contract No. DE-FG22-84PC3225 from NOXSO Corporation to the U.S. Department of Energy, Pittsburgh, PA, April, 1985

6. Keeth, R, J.E. Miranda, J.B. Reisdorf, R.W. Scheck. Economic Evaluation of FGD Systems. Vol.IV, EPRI, Palo Alto, CA, 1986.

7. Conversations with L.G. Neal, NOXSO Corporation, February, 1988.

8. Halsbeck, J.L., L.G. Neal, W.T. Ma. Development Status of the NOXSO Combined $\mathrm{NO}_{x} / \mathrm{SO}_{2}$ Flue Gas Treatment Process. Prepared by NOXSO Corporation for the Fourth Symposium on Integrated Environmental Control, Washington, D.C., March, 1988.

9. Steam /its generation and use. Babcock and Wilcox Company, New York, 1978.

10. Memo from NOXSO corporation, February, 1988.

11. TAG TM: Technical Assessment Guide. Electric Power Research Institute, P-4463-SR, Vol. 1-3, December, 1986. 


\section{Sulfuric Acid Plant}

This section of the report describes an update version of a sulfuric acid plant model developed by Frey [1]. The sulfuric acid plant performance and economic models were developed based on an interpass absorption (2/1) contact acid plant design by Monsanto for SMC [2,3]. Subsequent information from Monsanto [4,5], and studies [6] also were used for this model.

The Monsanto design has a conversiori efficiency of $99.5 \%$ and is based on a regenerator offgas composition specified by SMC, which consisted of $\mathrm{CH}_{4}, \mathrm{CO}_{2}, \mathrm{H}_{2} \mathrm{O}$, and $\mathrm{SO}_{2}$. The current design, shown in Figure 3-1, was modified to accommodate off-gases with different compositions, temperatures, and pressures. Presently it can handle these additional gases: $\mathrm{CO}$, COS, $\mathrm{H}_{2}, \mathrm{H}_{2} \mathrm{~S}, \mathrm{~N}_{2}, \mathrm{O}_{2}$, and $\mathrm{SO}_{2}$. The only major changes are an additional inlet gas compressor and gas burner. The inlet gas compressor is only used if the inlet off gas is below 97 " of water, while the gas burner is used to burn combustible compounds in the inlet gas. The inlet gas compressor and gas burner are shown in Figure 3-2.

To understand this model, it is important to understand the characteristics of contact acid plants, overall strategy, assumptions, and algorithms used for this model, and how it interacts with the rest of the IEC model. Contact acid plants have high initial capital cost and low operating cost, excluding utilities; therefore, it is more important to estimate the capital cost than the operating cost. The most expensive and critical component is the conveiter.

Anoth's i mportant point is that acid plants can either be net energy producers or consumers depending upon the composition of the inlet gas. So the amount of energy consumed and produced have to be accurately estimated. Acid plants are very reliable and maintenance requirements are small.

Generally an acid plant only has to be shut down once a year for a week, to maintain the catalyst in the converter. The attrition rate per year is approximately $2 \%$ fo: the entire converter, if the gas does not contain any dust, arsenic, chlorine, and flourine. Dust clogs the catalyst, while the other chemicals react with the catalyst and reduce its reactivity. The actual attrition rate per bed varies. The first stage or bed has the highest rate; the second stage has the second highest, and the last stage has the lowest. 
Figure 3-1: Schematic Diagram of Sulfuric Acid Plant
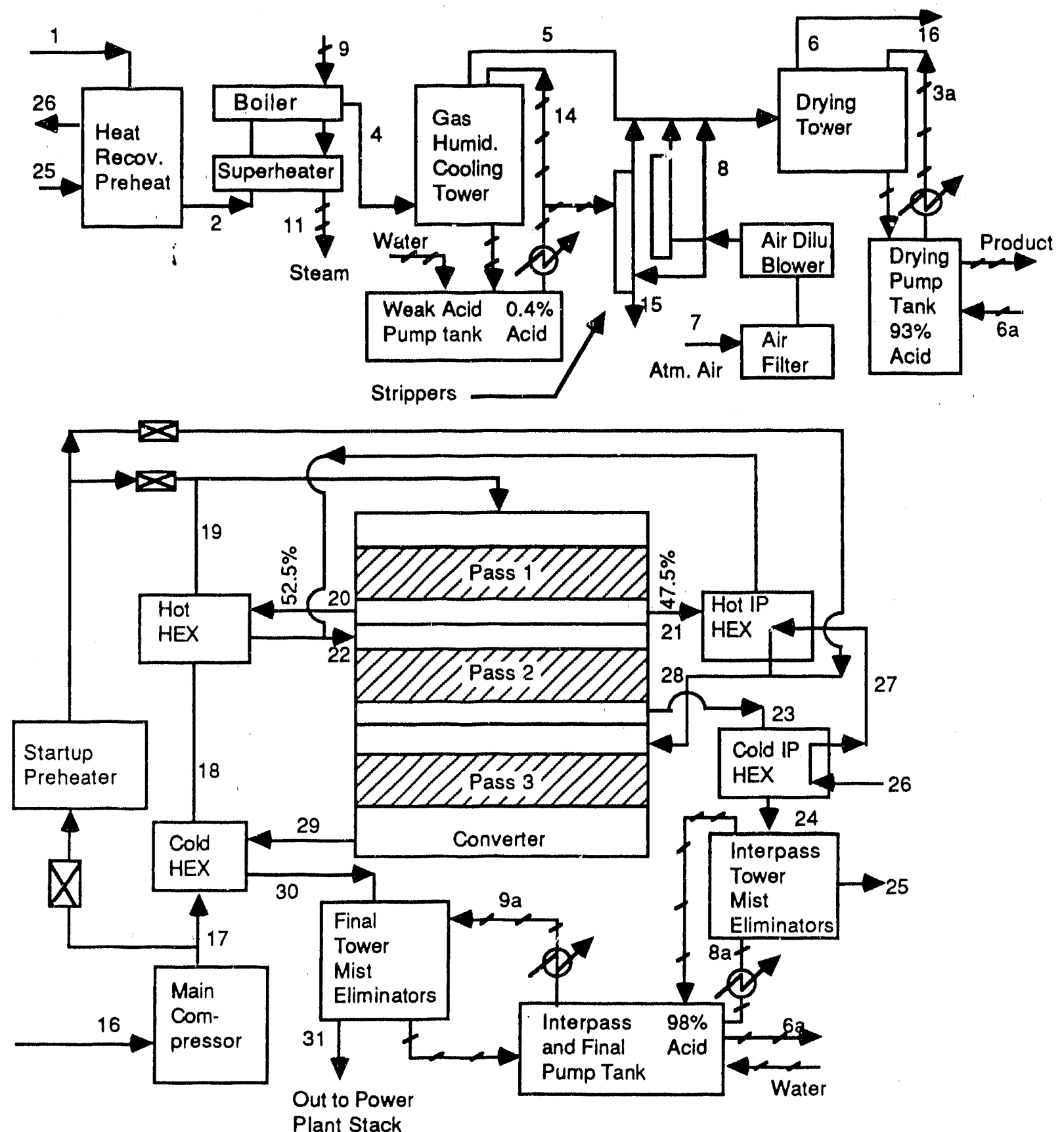

\begin{tabular}{l|r|r|r|r|r|r|r|r|r|r|r|r|r|r|r|} 
Stream & 1 & 2 & 4 & 5 & 6 & 7 & 8 & 9 & 11 & 14 & 16 & 17 & 18 & 19 & 20 \\
\cline { 2 - 21 } \\
$\begin{array}{l}\text { Temp. F } \\
\text { "Water }\end{array}$ & 609 & 506 & 169 & 120 & 85 & 115 & 226 & 450 & 163 & 120 & 171 & 603 & 779 & 1158 \\
\hline
\end{tabular}

Stream \begin{tabular}{|l|l|l|l|l|l|l|l|l|l|l|l|l|l|l|}
\hline 21 & 22 & 23 & 24 & 25 & 26 & 27 & 28 & 29 & 30 & 31 & $3 a$ & $6 a$ & $8 a$ & $9 a$ \\
\hline
\end{tabular}

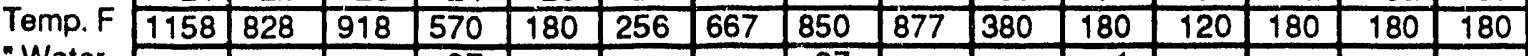

" Water 
Figure 3-2: Schematic Diagrams of Inlet Compressor and Gas Burner
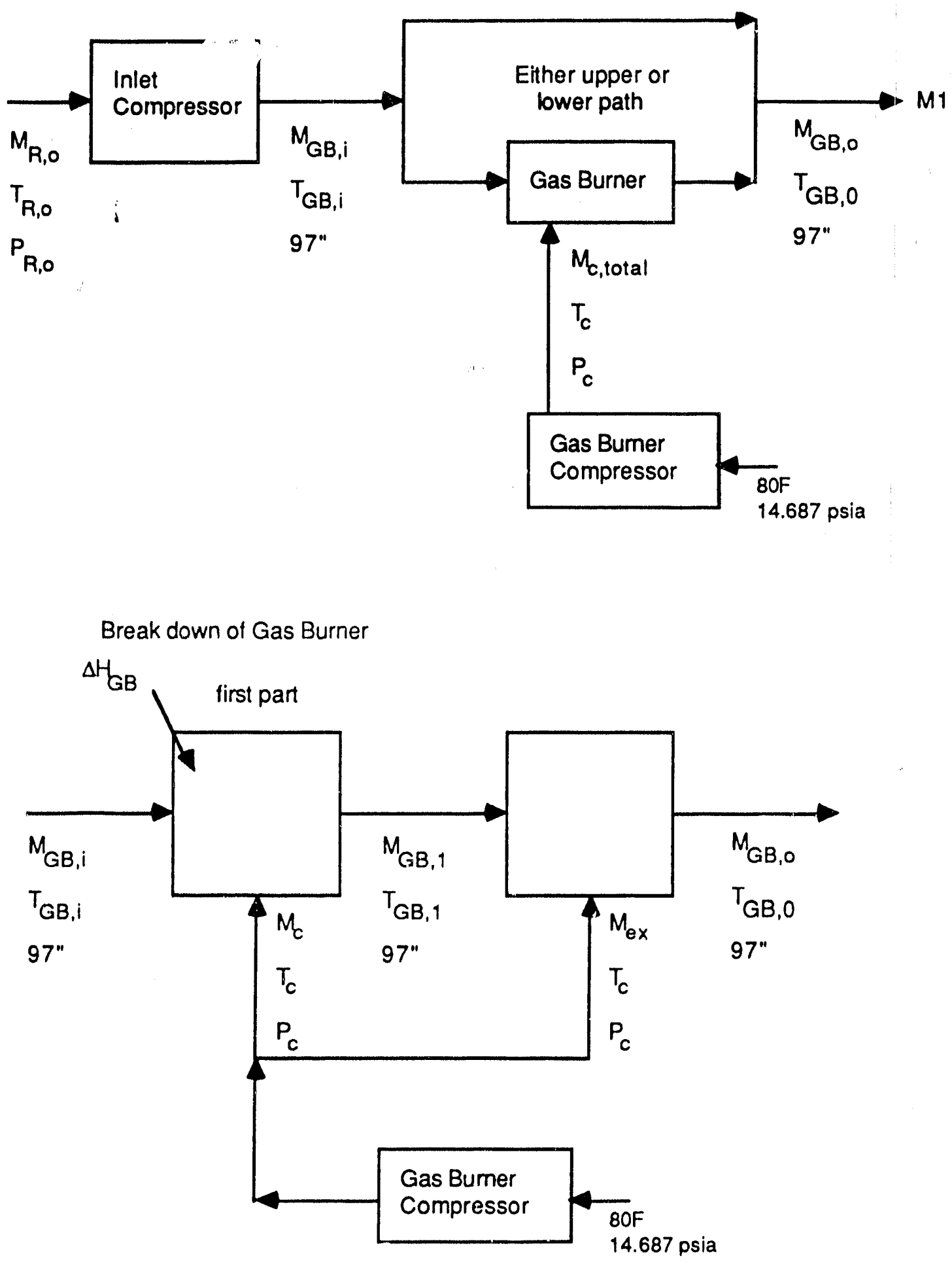
Before proceeding with a detailed description of the acid plant chemical processes, an overview is given below. It is assumed the reader will refer to Figures 3-1 and 3-2 for information to understand where the output of one piece of equipment is the input to another.

The principal steps of the process are:

- Oxidizing combustible gases other than $\mathrm{SO}_{2}$, if economical

- Gas purification, cooling, and drying

- Conversion of $\mathrm{SO}_{2}$ to $\mathrm{SO}_{3}$

- Conversion of $\mathrm{SO}_{3}$ to sulfuric acid

A contact sulfuric acid plant is based upon the chemical reaction of $\mathrm{SO}_{3}$ and $\mathrm{H}_{2} \mathrm{O}$ forming sulfuric acid. This reaction takes place in the final and interpass towers. The $\mathrm{SO}_{3}$ in the gas actually reacts with the water in the $98.5 \%$ sulfuric acid that is circulated through these towers. A strong acid is used to help prevent acid mist from forming.

Acid mist is formed if the $\mathrm{SO}_{3}$ is brought in contact with free water vapor. This acid mist can cause corrosion problems downstream unless it is removed. Some mist is always created, so mist eliminators are used downstream of the towers, although these are relatively expensive and have a significant pressure drop. To prevent moisture from entering the converter, drying towers are used upstream; however, moisture is also formed from any hydrogen compounds entering the converter, since they burn in the first stage.

The $\mathrm{SO}_{3}$ is generated in the converter by oxidizing $\mathrm{SO}_{2}$ in the presence of a catalyst. The oxidation of $\mathrm{SO}_{2}$ is highly temperature dependent. The rate of reaction increases with increasing temperature; however, the conversion efficiency decreases with increasing temperature. Therefore a three pass converter design is used to achieve a $99.5 \%$ conversion efficiency. The first stage oxides $70 \%$ of the $\mathrm{SO}_{2}$ operating at a temperature of $1158^{\circ} \mathrm{F}$; the second stage converts an additional $25 \%$ at $918^{\circ} \mathrm{F}$; the final stage converts all but the last $0.5 \%$ of the $\mathrm{SO}_{2}$ at $877^{\circ} \mathrm{F}$. The catalyst has a maximum operating temperature of $1158^{\circ} \mathrm{F}$, which is maintained by adding dilution air upstream of the converter. Since the oxidation of $\mathrm{SO}_{2}$ is exothermic, the maximum concentration of $\mathrm{SO}_{2}$ in the gas stream to the converter is approximately $11 \%$ if the gas streain does not contain any combustible gases. Any combustible gases in the inlet gas react with oxygen 
in the first stage and cause additional heat to be released in the first stage of the converter, so additional dilution air is required to ensure that the catalyst does not get too hot. This significantly increases the capital and operating costs. The amount of dilution air is determined by an energy balance on the first stage of the converter.

The gas niust be cooled for the second and third stages. This is accomplished by five heat exchanges which either $\mathrm{cnol}$ or heat the gas after it leaves the first stage. After the second stage, the gas passes through the interpass tower and mist eliminator which cools the gas and converts the $\mathrm{SO}_{3}$ into suifuric acid. The gas has to be heated for the third stage, so it passes through the heat recovery preheater and two heat exchangers.

The gas stream, 6, into the converter (see Figure 1) must be dry and hav's a maximum $\mathrm{SO}_{2}$ concentration of approximately $11 \%$. The gas is prepared by a series of heat exchangers and drying towers, upstream of the converter. The inlet gas stream, 1 , is cooled from $824^{\circ} \mathrm{F}$ to $609^{\circ} \mathrm{F}$ by the heat recovery preheater, while the gas stream, 25 , from the interpass tower is heated from $180^{\circ} \mathrm{F}$ to $256^{\circ} \mathrm{F}$. If the heat recovery preheater cools the inlet gas below $506^{\circ} \mathrm{F}$, the boiler or superheater are not used. This usually occurs when there are a lot combustible gases entering the converter. The combustible gases nicrease the dilution air requirement, which increases the size of stream 25 relative to stream 1 .

A gas burner can be used to burn any combustible gases before it enters the converter, and is usually placed upstream of the heat recovery preheater. These Evrners are fired by natural gas; however, it is assumed that the natural gas is just used to ignite and maintain combustion, and does not add any significant energy to the gas stream. Therefore the energy and molar balances ignore any effects of the natural gas. These bumers generally have a maximum temperature of $2000^{\circ} \mathrm{F}$, so additional air over stoichiometric may be needed to maintain this temperature. Using a gas burner increases the temperature and flow rate of the gases into the sieat recovery preheater, superheater, boiler, and gas humidification and cooling tower. The overall effect is to increase the cost of the superheater, boiler, gas humidification and cooling tower, weak acid, and effluent stripper components. However, the dilution air, inlet and exit converter flow raies are lower and additional energy is recovered by the superheater and boiler. This reduces the cost for the heat recovery preheater, dilution blower, drying tower and converter. These trade-offs make it difficult to 
determine a priori whether it is more profitable to use the gas burner, so the user must specify its use.

The boiler and superheater are primarily used to generate high quality steam, which can be used elsewhere in the power plant or to generate electricity. The gas humidification and cooling tower drops the temperature to $169^{\circ} \mathrm{F}$, while reducing the moisture content by $30 \%$. This is accomplished by circulating a weak acid through the gas.

Finally the dilution air is added to the inlet gas stream and this con sined stream is sent to the drying tower, which removes the remaining moisture by circulating a $93 \%$ acid through the gas. The dilution air is determined by an energy balance on the first stage of the converter.

\subsection{Performance Model for Acid Plant}

The sulfuric acid plant model developed is meant to respond to a number of the factors that affect sulfuric acid plant cost. These include the volume flow rate, moisture content, temperature, pressure, combustible gases, and $\mathrm{SO}_{2}$ content of the inlet gas stream. To achieve this, mass and energy balances are performed upon key components to determine critical mass and heat loads. These mass and heat loads are used to estimate the capital cost and operating cost.

To perform energy' balances, enthalpy data over a large temperature range $\left(77-3000^{\circ} \mathrm{F}\right)$ are needed for the 11 chemicals listed in the Introduction. These data are obtained by integrating the polynomial correlations for specific heat with respect to temperature obtain from Barin and Knacke [7] and Barin, Knacke and Kubaschewski [8]. These polynomial equations are functions in this model, and are explained in more detail in Appendix A. When a temperature of a gas flow needs to be estimated, an initial estimate is made, which is used to interpolate or extrapolate to the final estimated temperature. This procedure reduces the error to less than $5 \%$ and is also a non iterative technique. Some of the assumptions for this model are that the inlet gas is free of dust, ars $9.2 i c$, chlorine, and fluorine; that the inlet pressure entering the heat recovery preheater is $95-97$ " of water; and that the temperatures exiting the gas humidification and cooling tower and the drying tower are $169^{\circ} \mathrm{F}$ and $120^{\circ} \mathrm{F}$ respectively. The temperatures in the converter and exiting the heat exchangers surrounding it are the same as those estimated in the Monsanto design for SMC [2]. The pressure drops for all the equipment remains the same. The gases are assumed to be ideal, and 
all energy transfers are assumed to be adiabatic. The atmosphere is assumed to have a pressure of $14.687 \mathrm{psi}$, a temperature of $80^{\circ} \mathrm{F}$, contain $21 \%$ oxygen, $79 \%$ nitrogen on a dry basis, and 0.018 lbs moisture per pound of dry air. These values appear as constants in this report; however, they are actually variables in the model.

The first step is to calculate the characteristics of the inlet gas before and after the inlet compressor. The inlet compressor is used if the pressure exiting the regenerator is less than $95^{\prime \prime}$ of water. The gas flow rates are based on the ideal gas law, while the energy consumed by the compressor is depended upon the pressure difference. If the pressure difference is greater than $50^{\prime \prime}$ of water, a compressor is used with an efficiency of 75\% [9]; otherwise, a blower is used with an efficiency of $85 \%$ [10]. The main difference between a blower and a compressor is that a blowers pressure drop is low enough to assume incompressible flow. The temperature, inlet and exit gas flow rate and energy consumed by the inlet compressor are shown below.

$$
\begin{aligned}
& \mathrm{T}_{\mathrm{IC}, \mathrm{o}}=\left(\mathrm{T}_{\mathrm{R}, \mathrm{o}}+460\right)\left(\frac{14.687+3.612 \mathrm{e}^{-2 * 97}}{14.687+3.612 \mathrm{e}^{-2} \mathrm{P}_{\mathrm{R}, \mathrm{o}}}\right)^{\frac{1.4-1}{1.4}}-460 \\
& \mathrm{G}_{\mathrm{IC}, \mathrm{i}}=\frac{1545 \mathrm{M}_{\mathrm{R}, \mathrm{o}}\left(\mathrm{T}_{\mathrm{R}, \mathrm{o}}+460\right)}{60 * 144\left(14.687+3.612 \mathrm{e}^{-2} \mathrm{P}_{\mathrm{R}, \mathrm{o}}\right)} \\
& \mathrm{G}_{\mathrm{IC}, \mathrm{o}}=\frac{1545 \mathrm{M}_{\mathrm{R}, \mathrm{o}}\left(\mathrm{T}_{\mathrm{IC}, \mathrm{o}}+460\right)}{60 * 144\left(14.687+3.612 \mathrm{e}^{-2} * 97\right)} \\
& \text { if } \mathrm{P}_{\mathrm{R}, \mathrm{o}}<47 \text { then } \\
& \left.\mathrm{EC}_{\mathrm{IC}}=\left(\frac{1545 \mathrm{M}_{\mathrm{R}, \mathrm{o}}}{0.75 * 60 * 44,240}\right)\left(\frac{1.4}{1.4-1}\right)\left(\frac{14.687+3.612 \mathrm{e}^{-2 * 97}}{14.687+3.612 \mathrm{e}^{-2} \mathrm{P}_{\mathrm{R}, \mathrm{o}}}\right)^{\frac{1.4-1}{1.4}}-1\right]\left(\mathrm{T}_{\mathrm{R}, \mathrm{o}}+460\right) \\
& \text { else } \mathrm{EC}_{\mathrm{IC}}=1.38 \mathrm{e}^{-4} \mathrm{G}_{\mathrm{IC}, \mathrm{i}}\left(97-\mathrm{P}_{\mathrm{R}, \mathrm{o}}\right)
\end{aligned}
$$

The next step is to determine if the gas burner is used and it affects on the gas flow rate. The model assumes that the pressure drop across the gas burner is negligible. The gas burner is assumed to be fired by natural gas; however, it is also assumed that only enough natural gas is used to maintain and ignite the combustible gases in the inlet stream. Therefore, the energy and mass balances ignore the effects of it. The gas burner has a maximum operating temperature of 
$2000^{\circ} \mathrm{F}$, and completely oxide all the combustible gases. To prevent the gas burner from operating above $2000^{\circ} \mathrm{F}$, additional air is added above the stoichiometric requirement to oxides the combustible gases. To solve for the additional air requirement, the gas burner is assumed to be divided into two parts, shown in Figure 3-2. The first part burns the gases with 5\% excess air. If the total energy flow rate into the first part of the gas burner is greater than the energy flow rate of the exhaust gases at $2000^{\circ} \mathrm{F}$, then additional air is added. If it isn't, then the exit temperature of the gas burner is estimated by interpolating between the inlet temperature and $2000^{\circ} \mathrm{F}$. The oxygen needed for combustion is,

$$
\mathrm{M}_{\mathrm{O}, \mathrm{c}, 1}=2 \mathrm{M}_{\mathrm{M}, \mathrm{R}, \mathrm{O}}+0.5 \mathrm{M}_{\mathrm{H}, \mathrm{R}, \mathrm{o}}+0.5 \mathrm{M}_{\mathrm{CM}, \mathrm{R}, \mathrm{o}}+1.5 \mathrm{M}_{\mathrm{CS}, \mathrm{R}, \mathrm{o}}+1.5 \mathrm{M}_{\mathrm{HS}, \mathrm{R}, \mathrm{o}}+2 \mathrm{M}_{\mathrm{S}, \mathrm{R}, \mathrm{O}}
$$

The additional air needed for $5 \%$ excess air is,

$$
\begin{aligned}
& \text { if } 1.05 \mathrm{M}_{\mathrm{O}, \mathrm{c}, 1}>\mathrm{M}_{\mathrm{O}, \mathrm{R}, \mathrm{o}} \text { then } \\
& \qquad \mathrm{M}_{\mathrm{O}, \mathrm{c}}=1.05 \mathrm{M}_{\mathrm{O}, \mathrm{c}, 1}-\mathrm{M}_{\mathrm{O}, \mathrm{R}, \mathrm{O}} \\
& \text { else } \mathrm{M}_{\mathrm{O}, \mathrm{c}}=0 \\
& \mathrm{M}_{\mathrm{N}, \mathrm{c}}=3.76 \mathrm{M}_{\mathrm{O}, \mathrm{c}} \\
& \mathrm{M}_{\mathrm{W}, \mathrm{c}}=1.611 * 0.018\left(\mathrm{M}_{\mathrm{O}, \mathrm{c}}+\mathrm{M}_{\mathrm{N}, \mathrm{c}}\right)
\end{aligned}
$$

The combustion air has to be raised to $97^{\prime \prime}$ of water; therefore its temperature into the gas burne- is,

$$
T_{c}=(80+460)\left(\frac{14.687+3.612 e^{-2 * 97}}{14.687}\right)^{\frac{1.4-1}{1.4}}-460
$$

The next step is to determine the exhaust gases exiting the first part of the gas burner and the energy produced. It is assumed that all the methane, hydrogen, carbon monoxide, hydrogen sulfide, sulfur and $\operatorname{COS}$ are oxided.

$$
\begin{aligned}
& M_{j, G B, 1}=0 \\
& M_{S D, G B, 1}=M_{S D, R, o}+M_{C S, R, o}+M_{H S, R, o}+2 M_{S, R, o} \\
& M_{W, G B, 1}=M_{W, R, o}+M_{W, c}+2 M_{M, R, o}+M_{H, R, o}+M_{H S, R, o} \\
& M_{C D, G B, 1}=M_{C D, R, o}+M_{M, R, o}+M_{C M, R, o}+M_{C S, R, o} \\
& M_{N, G B, 1}=M_{N, R, o}+M_{W, c}
\end{aligned}
$$




$$
\begin{aligned}
& \text { if } \mathrm{M}_{\mathrm{O}, \mathrm{R}, \mathrm{o}}>1.05 \mathrm{M}_{\mathrm{O}, \mathrm{c}, 1} \text { then } \\
& \qquad \mathrm{M}_{\mathrm{O}, \mathrm{GB}, 1}=\mathrm{M}_{\mathrm{O}, \mathrm{R}, \mathrm{o}}-\mathrm{M}_{\mathrm{O}, \mathrm{c}, 1} \\
& \text { else } \mathrm{M}_{\mathrm{O}, \mathrm{GB}, 1}=0.05 \mathrm{M}_{\mathrm{O}, \mathrm{c}, 1} \\
& \text { where } \mathrm{j}=\mathrm{CM}, \mathrm{CS}, \mathrm{H}, \mathrm{HS}, \mathrm{M}, \mathrm{S} \\
& \begin{aligned}
\Delta \mathrm{H}_{\mathrm{GB}}= & 345,200 \mathrm{M}_{\mathrm{M}}+104,000 \mathrm{M}_{\mathrm{H}}+121,700 \mathrm{M}_{\mathrm{CM}}+255,400 \mathrm{M}_{\mathrm{S}}+ \\
& 222,900 \mathrm{M}_{\mathrm{HS}}+236,000 \mathrm{M}_{\mathrm{CS}}
\end{aligned}
\end{aligned}
$$

Now an energy balance is performed upon the first part of the gas burner to see in more air is needed to cool the gas burner. Two estimates are made for the exit temperature: one is made at the maximum allowable temperature of $2000^{\circ} \mathrm{F}$, the other is made at the inlet temperature. If the total energy entering the gas burner is greater the the energy flow rate of the exhaust gases at $2000^{\circ} \mathrm{F}$, then additional air is needed to cool the gas. If the temperature is less than $2000^{\circ} \mathrm{F}$, then no additional air is added, and the exit temperature is estimated by a linear interpolation between the inlet temperature and $2000^{\circ} \mathrm{F}$. Finally, the total molar and volumetric flow rates of the combustion air are calculated, along with the energy consumed by the gas burner combustion air compressor.

$$
\begin{aligned}
& \mathrm{E}_{\mathrm{GB}, \mathrm{i}}=\sum_{\mathrm{k}=1}^{11} \hat{\mathrm{h}}_{\mathrm{k}}\left(\mathrm{T}_{\mathrm{GB}, \mathrm{i}}\right) \mathrm{M}_{\mathrm{GB}, \mathrm{i}} \\
& \mathrm{E}_{\mathrm{c}}=\hat{\mathrm{h}}_{\mathrm{O}}\left(\mathrm{T}_{\mathrm{c}}\right) \mathrm{M}_{\mathrm{O}, \mathrm{c}}+\hat{\mathrm{h}}_{\mathrm{N}}\left(\mathrm{T}_{\mathrm{c}}\right) \mathrm{M}_{\mathrm{N}, \mathrm{c}}+\hat{\mathrm{h}}_{\mathrm{W}, \mathrm{c}}\left(\mathrm{T}_{\mathrm{c}}\right) \mathrm{M}_{\mathrm{w}, \mathrm{c}} \\
& \mathrm{E}_{\mathrm{GB}, \text { total }}=\mathrm{E}_{\mathrm{BG}, \mathrm{i}}+\mathrm{E}_{\mathrm{c}}+\Delta \mathrm{H}_{\mathrm{GB}} \\
& \mathrm{E}_{\mathrm{GB}, \max }=\sum_{\mathrm{j}=1}^{5} \hat{\mathrm{h}}_{\mathrm{j}}(2000) \mathrm{M}_{\mathrm{j}, 1} \\
& \mathrm{E}_{\mathrm{GB}, \min }=\sum_{\mathrm{j}=1}^{5} \hat{\mathrm{h}}_{\mathrm{j}}\left(\mathrm{T}_{\mathrm{GB}, \mathrm{i}}\right) \mathrm{M}_{\mathrm{j}, 1}
\end{aligned}
$$

where $\mathrm{k}=\mathrm{CD}, \mathrm{CM}, \mathrm{CS}, \mathrm{H}, \mathrm{HS}, \mathrm{M}, \mathrm{N}, \mathrm{O}, \mathrm{S}, \mathrm{SD}, \mathrm{W}$

and $\mathrm{j}=\mathrm{CD}, \mathrm{N}, \mathrm{O}, \mathrm{SD}, \mathrm{W}$ 


$$
\begin{aligned}
& \text { if } E_{G B, \text { total }}>E_{G B, \max } \text { then } \\
& M_{\mathrm{O}, \mathrm{ex}}=\frac{\mathrm{E}_{\mathrm{GB}, \text { total }}-\mathrm{E}_{\mathrm{GB}, \max }}{15,180-\hat{h}_{\mathrm{O}}\left(\mathrm{T}_{\mathrm{c}}\right)+3.76\left(14,440-\hat{\mathrm{h}}_{\mathrm{N}}\left(\mathrm{T}_{\mathrm{c}}\right)\right)+1.611 * 0.018 *\left(17,920-\hat{\mathrm{h}}_{\mathrm{W}}\left(\mathrm{T}_{\mathrm{c}}\right)\right)} \\
& \mathrm{T}_{\mathrm{GB}, \mathrm{O}}=2000 \\
& \text { else } M_{o, e x}=0 \\
& T_{G B, o}=\frac{2000-T_{G B, i}}{E_{G B, \max }-E_{G B, \min }}\left(E_{G B, \text { total }}-E_{G B, \min }\right)+T_{G B, i} \\
& \mathrm{M}_{\mathrm{N}, \mathrm{ex}}=3.76 \mathrm{M}_{\mathrm{O}, \mathrm{ex}} \\
& \mathrm{M}_{\mathrm{W}, \mathrm{ex}}=1.611 * 0.018 * 4.76 \mathrm{M}_{\mathrm{O}, \mathrm{ex}} \\
& \mathrm{M}_{\mathrm{c}, \text { total }}=\mathrm{M}_{\mathrm{O}, \mathrm{c}}+\mathrm{M}_{\mathrm{N}, \mathrm{c}}+\mathrm{M}_{\mathrm{W}, \mathrm{c}}+\mathrm{M}_{\mathrm{O}, \mathrm{ex}}+\mathrm{M}_{\mathrm{N}, \mathrm{ex}}+\mathrm{M}_{\mathrm{W}, \mathrm{ex}} \\
& G_{c, \text { total }}=\frac{1545 M_{c, \text { total }}(80+460)}{60 * 14.687 * 144} \\
& \mathrm{EC}_{\mathrm{GBC}}=\left(\frac{1545 \mathrm{M}_{\mathrm{c}, \text { total }}}{0.75 * 60 * 44,240}\right)\left(\frac{1.4}{1.4-1}\right)\left[\left(\frac{14.687+3.612 \mathrm{e}^{-2} * 97}{14.687}\right)^{\frac{1.4-1}{1.4}}-1\right](80+460)
\end{aligned}
$$

The next step is to determine the composition and temperature of the gas stearn entering the heat recovery preheater. It should be noted that the composition of the gas stream between the gas burner and the first stage of the converter is the same, except for the moisture content. This allows the use of the same variable names for the composition of the gas stream between the gas burner and converter, which saves space and increases execution speed. The composition of the gas stream entering the heat recovery preheater depends on whether the gas burner is used. If it isn't used, the composition and temperature are the same as those exiting the regenerator.

If a gas burner is not used then,

$$
\begin{aligned}
& M_{k, H P, i}=M_{k, R, o} \\
& T_{H P, i}=T_{R, o}
\end{aligned}
$$


else

$$
\begin{aligned}
& \mathrm{M}_{\mathrm{j}, \mathrm{HP}, \mathrm{i}}=0 \\
& \mathrm{M}_{\mathrm{SD}, \mathrm{HP}, \mathrm{i}}=\mathrm{M}_{\mathrm{SD}, \mathrm{GB}, 1} \\
& \mathrm{M}_{\mathrm{CD}, \mathrm{HP}, \mathrm{i}}=\mathrm{M}_{\mathrm{CD}, \mathrm{GB}, 1} \\
& \mathrm{M}_{\mathrm{W}, \mathrm{HP}, \mathrm{i}}=\mathrm{M}_{\mathrm{W}, \mathrm{GB}, 1}+\mathrm{M}_{\mathrm{W}, \mathrm{ex}} \\
& \mathrm{M}_{\mathrm{N}, \mathrm{HP}, \mathrm{i}}=\mathrm{M}_{\mathrm{N}, \mathrm{GB}, 1}+\mathrm{M}_{\mathrm{N}, \mathrm{ex}} \\
& \mathrm{M}_{\mathrm{O}, \mathrm{HP}, \mathrm{i}}=\mathrm{M}_{\mathrm{O}, \mathrm{GB}, 1}+\mathrm{M}_{\mathrm{O}, \mathrm{ex}} \\
& \mathrm{T}_{\mathrm{HP}, \mathrm{i}}=\mathrm{T}_{\mathrm{GB}, \mathrm{O}} \\
& \mathrm{M}_{\mathrm{HP}, \mathrm{i}}=\sum_{\mathrm{k}=1}^{11} \mathrm{M}_{\mathrm{k}, \mathrm{HP}, \mathrm{i}} \\
& \mathrm{G}_{\mathrm{HP}, \mathrm{i}}=\frac{1545 \mathrm{M}_{\mathrm{HP}, \mathrm{i}}\left(\mathrm{T}_{\mathrm{HP}, \mathrm{i}}+460\right)}{60 * 144 *\left(14.687+3.612 \mathrm{e}^{-2 * 97)}\right.} \\
& \text { where } \mathrm{k}=\mathrm{CD}, \mathrm{CM}, \mathrm{CS}, \mathrm{H}, \mathrm{HS}, \mathrm{M}, \mathrm{N}, \mathrm{O}, \mathrm{S}, \mathrm{SD}, \mathrm{W} \\
& \text { and } \mathrm{j}=\mathrm{CM}, \mathrm{CS}, \mathrm{H}, \mathrm{HS}, \mathrm{M}, \mathrm{S}
\end{aligned}
$$

So far the algorithms has followed the gas stream into the acid plant, and it would seem logical to model the heat recovery preheater next. However, the heat load on the preheater is determined by the gas flow exiting the second stage of the converter, M25, which hasn't been determined, and this gas flow is depended upon the gas flow entering the converter. This cyclic problem is eliminated by the assumptions made at the beginning of this section and noting that the composition of the gas entering the converter can be predictec' by the composition exiting the gas burner. Another important assumption is dividing the first stage of the converter into two parts. The first part burns the combustible gases and converts $70 \%$ of the $\mathrm{SO}_{2}$ to $\mathrm{SO}_{3}$; the second part adds dilution air to lower the temperature to $1158^{\circ} \mathrm{F}$. This is the same procedure used for the gas burner. Some other important points are:

- The combustible gases entering the converter are, the same as those exiting the gas burner; therefore, the energy released in the first stage of the converter can be determined.

- The oxygen requirement for complete conversion of $\mathrm{SO}_{2}$ to $\mathrm{SO}_{3}$ and the oxidation of the other combustible gases can be calculated.

- The gas entering the first stage of the converter is assumed to be $997^{\circ} \mathrm{F}$, and free of moisture, since the drying tower removes all moisture. 
The oxygen consumed in the first stage is calculated, along with the oxygen needed for oxidization all the combustible gases and converting all the $\mathrm{SO}_{2}$ to $\mathrm{SO}_{3}$ is calculated below. This ensures that enough oxygen is available to convert the $\mathrm{SO}_{2}$ to $\mathrm{SO}_{3}$. Once these values are known the composition of the gas exiting the converter, not including additional dilution air needed to maintain $1158^{\circ} \mathrm{F}$, can be determined:

$$
\begin{aligned}
& \mathrm{M}_{\mathrm{O}, \mathrm{CS}, 1}=2 \mathrm{M}_{\mathrm{M}, \mathrm{PH}, \mathrm{i}}+0.5 \mathrm{M}_{\mathrm{CM}, \mathrm{PH}, \mathrm{i}}+0.5 \mathrm{M}_{\mathrm{H}, \mathrm{PH}, \mathrm{i}}+0.35 \mathrm{M}_{\mathrm{SD}, \mathrm{PH}, \mathrm{i}}+1.85 \mathrm{M}_{\mathrm{CS}, \mathrm{PH}, \mathrm{i}}+ \\
& 1.85 \mathrm{M}_{\mathrm{HS}, \mathrm{PH}, \mathrm{i}}+2.7 \mathrm{M}_{\mathrm{S}, \mathrm{PH}, \mathrm{i}} \\
& \mathrm{M}_{\mathrm{O}, \mathrm{CS}, \mathrm{all}}=2 \mathrm{M}_{\mathrm{M}, \mathrm{PH}, \mathrm{i}}+0.5 \mathrm{M}_{\mathrm{CM}, \mathrm{PH}, \mathrm{i}}+0.5 \mathrm{M}_{\mathrm{H}, \mathrm{PH}, \mathrm{i}}+0.5 \mathrm{M}_{\mathrm{SD}, \mathrm{PH}, \mathrm{i}}+2 \mathrm{M}_{\mathrm{CS}, \mathrm{PH}, \mathrm{i}}+ \\
& 2 \mathrm{M}_{\mathrm{HS}, \mathrm{PH}, \mathrm{i}}+3 \mathrm{M}_{\mathrm{S}, \mathrm{PH}, \mathrm{i}} \\
& \text { if } \mathrm{M}_{\mathrm{O}, \mathrm{CS}, \mathrm{all}}>\mathrm{M}_{\mathrm{O}, \mathrm{PH}, \mathrm{i}} \text { then } \mathrm{M}_{\mathrm{O}, \mathrm{CS}, \mathrm{c}}=\mathrm{M}_{\mathrm{O}, \mathrm{CS}, \mathrm{all}}-\mathrm{M}_{\mathrm{O}, \mathrm{PH}, \mathrm{i}} \\
& \text { else } \mathrm{M}_{\mathrm{O}, \mathrm{CS}, \mathrm{c}}=0 \\
& \mathrm{M}_{\mathrm{N}, \mathrm{CS}, \mathrm{c}}=3.76 \mathrm{M}_{\mathrm{O}, \mathrm{CS}, \mathrm{c}} \\
& \mathrm{M}_{\mathrm{W}, \mathrm{CS}, \mathrm{c}}=1.611 * 0.018\left(\mathrm{M}_{\mathrm{O}, \mathrm{CS}, \mathrm{c}}+\mathrm{M}_{\mathrm{O}, \mathrm{CS}, \mathrm{c}}\right) \\
& \text { if } \mathrm{M}_{\mathrm{O}, \mathrm{CS}, \mathrm{all}}>\mathrm{M}_{\mathrm{O}, \mathrm{PH}, \mathrm{i}} \text { then } \mathrm{M}_{\mathrm{O}, \mathrm{CS}, 1, \mathrm{O}}=\mathrm{M}_{\mathrm{O}, \mathrm{CS}, \mathrm{all}}-\mathrm{M}_{\mathrm{O}, \mathrm{CS}, 1} \\
& \text { else } M_{O, C S, 1,0}=M_{O, P H, i}-M_{O, C S, 1} \\
& \mathrm{M}_{\mathrm{N}, \mathrm{CS}, 1, \mathrm{o}}=\mathrm{M}_{\mathrm{N}, \mathrm{PH}, \mathrm{i}}+\mathrm{M}_{\mathrm{N}, \mathrm{CS}, \mathrm{c}} \\
& \mathrm{M}_{\mathrm{CD}, \mathrm{CS}, \mathrm{1}, \mathrm{o}}=\mathrm{M}_{\mathrm{CD}, \mathrm{PH}, \mathrm{i}}+\mathrm{M}_{\mathrm{M}, \mathrm{PH}, \mathrm{i}}+\mathrm{M}_{\mathrm{CM}, \mathrm{PH}, \mathrm{i}}+\mathrm{M}_{\mathrm{CS}, \mathrm{PH}, \mathrm{i}} \\
& \mathrm{M}_{\mathrm{W}, \mathrm{CS}, 1, \mathrm{O}}=\mathrm{M}_{\mathrm{H}, \mathrm{PH}, \mathrm{i}}+2 \mathrm{M}_{\mathrm{M}, \mathrm{PH}, \mathrm{i}}+\mathrm{M}_{\mathrm{HS}, \mathrm{PH}, \mathrm{i}} \\
& \mathrm{M}_{\mathrm{ST}, \mathrm{CS}, 1, \mathrm{O}}=0.7\left(\mathrm{M}_{\mathrm{SD}, \mathrm{PH}, \mathrm{i}}+2 \mathrm{M}_{\mathrm{S}, \mathrm{PH}, \mathrm{i}}+\mathrm{M}_{\mathrm{HS}, \mathrm{PH}, \mathrm{i}}+\mathrm{M}_{\mathrm{CS}, \mathrm{PH}, \mathrm{i}}\right) \\
& \mathrm{M}_{\mathrm{SD}, \mathrm{CS}, 1, \mathrm{O}}=0.3\left(\mathrm{M}_{\mathrm{SD}, \mathrm{PH}, \mathrm{i}}+2 \mathrm{M}_{\mathrm{S}, \mathrm{PH}, \mathrm{i}}+\mathrm{M}_{\mathrm{HS}, \mathrm{PH}, \mathrm{i}}+\mathrm{M}_{\mathrm{CS}, \mathrm{PH}, \mathrm{i}}\right)
\end{aligned}
$$

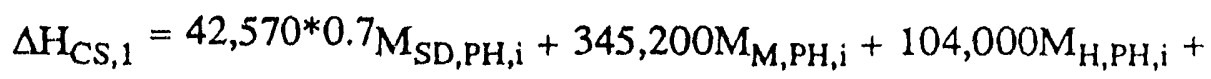

$$
\begin{aligned}
& 121,700 \mathrm{M}_{\mathrm{CM}, \mathrm{PH}, \mathrm{i}}+315,000 \mathrm{M}_{\mathrm{S}, \mathrm{PH}, \mathrm{i}}+261,500 \mathrm{M}_{\mathrm{HS}, \mathrm{PH}, \mathrm{i}}+265,800 \mathrm{M}_{\mathrm{CS}, \mathrm{PH}, \mathrm{i}}
\end{aligned}
$$

With this information an energy balance can be performed on the second part of the first stage to determine the additional amount of dry air needed to cool the catalyst to $1158^{\circ} \mathrm{F}$. Then the total molar flow rate of moist dilution air can be calculated. The energy flow rate into the second part of the first stage is the energy flow of all the species entering the heat recovery preheater at $779^{\circ} \mathrm{F}$, except for the moisture, plus the energy flow from the combustion air at $779^{\circ} \mathrm{F}$, plus the energy 
released in the first part. The energy flow out of the second part of the first stage is the sum of the product gases at $1158^{\circ} \mathrm{F}$. The constants in Equation 3.49 are the enthalpies of oxygen and nitrogen at $779^{\circ} \mathrm{F}$. The constant 2864.2 in Equation 3.51 is the enthalpy difference for dry air between $1158^{\circ} \mathrm{F}$ and $779^{\circ} \mathrm{F}$.

$$
\begin{aligned}
& \mathrm{E}_{\mathrm{CS}, 1}=\sum_{\mathrm{k}=1}^{10} \hat{h}_{\mathrm{j}}(779) \mathrm{M}_{\mathrm{k}, \mathrm{PH}, \mathrm{i}}+5,235.7 \mathrm{M}_{\mathrm{O}, \mathrm{CS}, \mathrm{c}}+5,028.4 \mathrm{M}_{\mathrm{N}, \mathrm{CS}, \mathrm{c}}+\Delta \mathrm{H}_{\mathrm{S}, 1} \\
& E_{C S, 1, \max }=\sum_{j=1}^{6} \hat{h}_{j}(1158) M_{j, C S, 1,0} \\
& \mathrm{M}_{\mathrm{air}, \mathrm{CS}, \mathrm{ex}}=\frac{\mathrm{E}_{\mathrm{CS}, 1}-\mathrm{E}_{\mathrm{CS}, 1, \mathrm{max}}}{2,864.2} \\
& M_{B F}=(1+1.611 * 0.018) M_{\text {air, CS,ex }}+M_{O, C S, c}+M_{N, C S, c}+M_{W, C S, c} \\
& \text { where } \mathrm{k}=\mathrm{CD}, \mathrm{CM}, \mathrm{CS}, \mathrm{H}, \mathrm{HS}, \mathrm{M}, \mathrm{N}, \mathrm{O}, \mathrm{S}, \mathrm{SD} \\
& \text { and } \mathrm{j}=\mathrm{CD}, \mathrm{N}, \mathrm{O}, \mathrm{SD}, \mathrm{ST}, \mathrm{W}
\end{aligned}
$$

Now the molar flow rates for the gas streams 'entering and exiting the drying tower and gas streams, $23 \& 25$ can be determined. The gas stream entering the drying tower is the same as the gas stream entering the heat recovery preheater minus the moisture removed in the gas humidification and cooling tower plus the moist dilution air. This includes all the moisture added with the dilution air, since the dilution air compressor is upstream of the drying tower. The gas streams, $23 \& 25$, are a bit more complicated to figure out. Stream 23 is after the second stage of the converter, which converts an additional $83 \%$ of the $\mathrm{SO}_{2}$ exiting the first stage to $\mathrm{SO}_{3}$, which consumes oxygen. Therefore gas stream 23 is the sum of $\mathrm{M}_{\mathrm{k}, \mathrm{CS}, 1,0}$, the air added for temperature control, $\mathrm{M}_{\mathrm{air}, \mathrm{CS}, e x}$, minus the oxygen consumed in the second stage. After the second stage it passes through the interpass tower, which removes all the moisture and converts all the $\mathrm{SO}_{3}$ to sulfuric acid. Note that the variables $M_{N, C S, 1,0}, M_{O, C S, 1,0}$, and $M_{C D, C S, 1,0}$ do not include the dry air needed to cool the catalyst to $1158^{\circ} \mathrm{F}$.

$$
\begin{aligned}
& M_{D, i}=M_{P H, i}+M_{B F}-0.3 M_{W, P H, i} \\
& M_{D, o}=M_{D, i}-0.7 M_{W, P H, i}-1.611 * 0.018 M_{a i r, C S, e x}-M_{W, C S, c} \\
& M_{23}=\sum_{k=1}^{6} M_{k, C S, 1,0}+M_{\text {air,CS,ex }}-0.5 * 0.83 M_{S D, C S, 1, o} \\
& M_{C D, 25}=M_{C D, C S, 1,0}
\end{aligned}
$$




$$
\begin{aligned}
& \mathrm{M}_{\mathrm{N}, 25}=\mathrm{M}_{\mathrm{N}, C S, 1,0}+0.79 \mathrm{M}_{\mathrm{air}, \mathrm{CS}, \mathrm{ex}} \\
& \mathrm{M}_{\mathrm{O}, 25}=\mathrm{M}_{\mathrm{O}, \mathrm{CS}, 1, \mathrm{0}}+0.21 \mathrm{M}_{\mathrm{air}, \mathrm{CS}, \mathrm{ex}}-0.5 * 0.83^{*} \mathrm{M}_{\mathrm{SD}, \mathrm{CS}, 1,0} \\
& \mathrm{M}_{\mathrm{SD}, 25}=0.17 \mathrm{M}_{\mathrm{SD}, \mathrm{CS}, 1,0} \\
& \mathrm{M}_{25}=\sum_{\mathrm{j}=1}^{4} \mathrm{M}_{\mathrm{j}, 25} \\
& \text { where } \mathrm{k}=\mathrm{CD}, \mathrm{N}, \mathrm{O}, \mathrm{SD}, \mathrm{ST}, \mathrm{W} \\
& \text { and j}=\mathrm{CD}, \mathrm{N}, \mathrm{O}, \mathrm{SD}
\end{aligned}
$$

With this information, it is possible to model the heat recovery preheater, superheater, and boiler. Schematic diagrams for the heat recovery preheater, boiler, and superheater are shown in Figure 3-3. The factor which will most directly affect the cost of heat exchangers are the required heat transfer surface area. This is calculated based on knowledge of the heat transfer load, the heat transfer coefficient $U$, and the log mean temperature difference (LMTD) for the heat exchanger. The heat transfer coefficients for the heat recovery preheater, superheater, and boiler are 4.5, 6 , and 15 respectively, which are taken from the Monsanto design.

The heat load in the heat recovery preheater is energy needed to raise the gas stream, 25, from $180^{\circ} \mathrm{F}$ to $256^{\circ} \mathrm{F}$. The exit temperature of the heat recovery preheater is estimated by making a guess of the exit temperature based on the ratio of the heat load to the energy entering heat recovery preheater. This algorithm is used instead of a constant since it provides a reasonable estimate of the exit temperature. This temperature estimate is used to estimate the energy flow rate exiting the heat recovery preheater. The energy estimate is used to calculate the exit temperature. The exit temperature is used to calculate the log mean temperature difference, which is used to determine the area of the heat recovery preheater.

$$
\begin{aligned}
& Q_{H P}=\sum_{j=1}^{4}\left(\hat{h}_{j}(256)-\hat{h}_{j}(180)\right) M_{j, 25} \\
& E_{H P, i}=\sum_{k=1}^{11} \hat{h}_{k}\left(T_{H P, i}\right) M_{k} \\
& T_{\text {guess }}=T_{H P, i}\left(1-\frac{Q_{H P}}{E_{H P, i}}\right)
\end{aligned}
$$


Figure 3-3: Inlet yisis Cooling Heat Exchangers

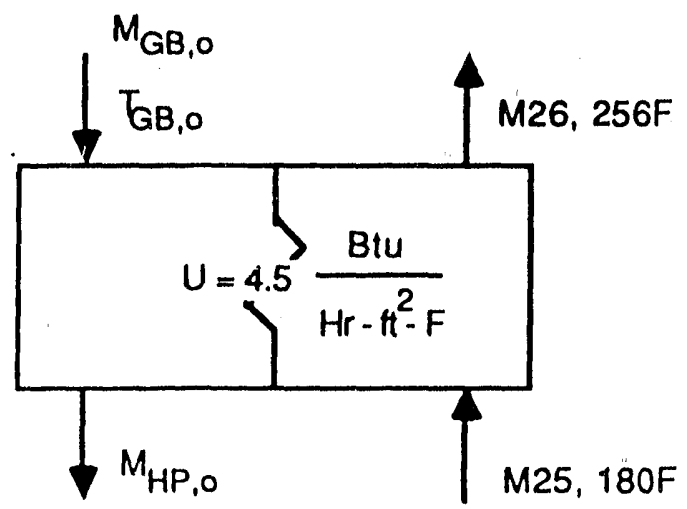

(a) Heat Recovery Preheater

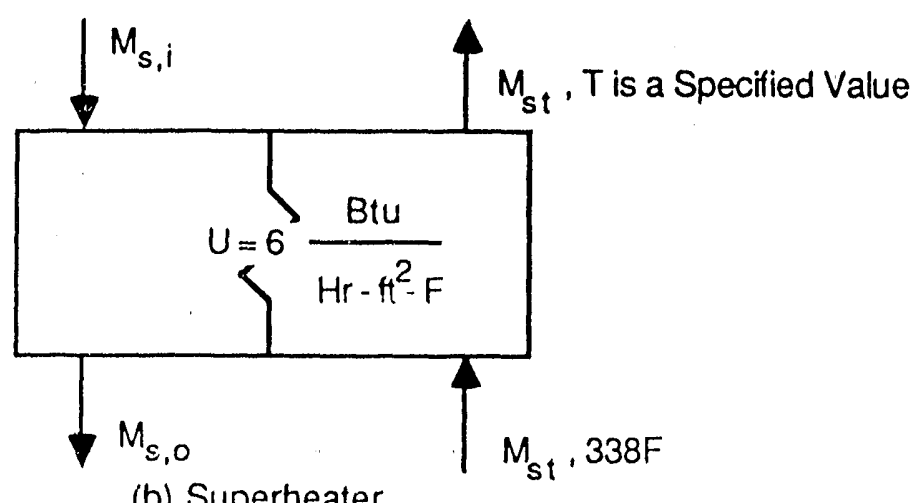

(b) Superheater

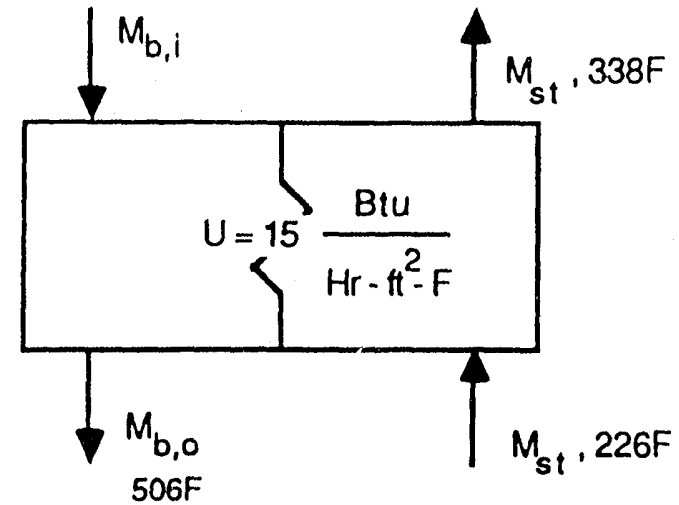

(c) Boiler 


$$
\begin{aligned}
& \mathrm{E}_{\text {guess }}=\sum_{\mathrm{k}=1}^{11} \hat{h}_{\mathrm{k}}\left(\mathrm{T}_{\text {guess }}\right) \mathrm{M}_{\mathrm{k}} \\
& \text { where } \mathrm{j}=\mathrm{CD}, \mathrm{N}, \mathrm{O}, \mathrm{SD} \\
& \text { and } \mathrm{k}=\mathrm{CD}, \mathrm{CM}, \mathrm{CS}, \mathrm{H}, \mathrm{HS}, \mathrm{M}, \mathrm{N}, \mathrm{O}, \mathrm{S}, \mathrm{SD}, \mathrm{W} \\
& \mathrm{T}_{\mathrm{HP}, \mathrm{o}}=-\mathrm{Q}_{\mathrm{HP}} \frac{\mathrm{T}_{\mathrm{HP}, \mathrm{i}}-\mathrm{T}_{\text {guess }}}{\mathrm{E}_{\mathrm{HP}, \mathrm{i}}-\mathrm{E}_{\text {guess }}}+\mathrm{T}_{\mathrm{HP}, \mathrm{i}} \\
& \mathrm{LMTD}_{\mathrm{HP}}=\frac{\left(\mathrm{T}_{\mathrm{HP}, \mathrm{i}}-256\right)-\left(\mathrm{T}_{\mathrm{HP}, \mathrm{o}}-180\right)}{\ln \left(\frac{\mathrm{T}_{\mathrm{HP}, \mathrm{i}}-256}{\mathrm{~T}_{\mathrm{HP}, \mathrm{o}}-180}\right)} \\
& \mathrm{A}_{\mathrm{HP}}=\frac{\mathrm{Q}_{\mathrm{HP}}}{4.5 \mathrm{LMTD}}{ }_{\mathrm{HP}}
\end{aligned}
$$

The calculations for the boiler and superheater are similar, except that first the amount of water that can be heated to steam must be determined, and then the calculations for the LMTD and heat transfer areas of the boiler and superheater can be made. In order to parallel the design work performed by Monsanto, the off-gas temperature leaving the boiler is specified as $506^{\circ} \mathrm{F}$, unless the exit temperature of the heat recovery preheater is less. If this occurs, the superheater and boiler are not used, no steam is generated, and the temperature of the gas entering the gas humidification and cooling tower is the exit temperature of the heat recovery preheater. ${ }^{2}$

The water mass flow rate required for conversion to steam is calculated by determining how much energy is available in the hot regenerator off-gas to heat water from $226^{\circ} \mathrm{F}$ to superheated steam at a specified temperature and 100 psia. The constant 17,929 is the energy needed to raise a mole of saturated water at 226 to $338^{\circ} \mathrm{F}$, while 2134.8 is the enthalpy of saturated steam at $338^{\circ} \mathrm{F}$. The temperature of the superheated steam is a user specified value, since this steam can be used by some FGD processes, which require steam at different temperatures.

$$
E_{H P, o}=E_{H P, i}-Q_{H P}
$$

2 Instead of testing the exit temperature of the heat recovery preheater to see if it is greater than 506, the energy flow of the gas stream exiting the heat recovery preheater is compared against the energy flow of the gas stream at 506. This method is used since the exit temperature is just an interpolated estimate, while the energy flow exiting the preheaier can be determine more accurately by subtracting the heat load from the energy entering the preheater. 


$$
\begin{aligned}
& E_{506}=\sum_{k=1}^{11} \hat{h}_{k}(506) M_{k} \\
& \text { if } E_{H P, o}>E_{506} \text { then } \\
& E_{G C, i}=E_{506} \\
& T_{G C, i}=506 \\
& \text { else } \\
& E_{G C, i}=E_{H P, o} \\
& T_{G C, i}=T_{H P, o} \\
& M_{s t}=\frac{E_{H P, o}-E_{G C, i}}{\hat{h}_{W}\left(T_{\text {specified }}\right)-2134.8+17,929}
\end{aligned}
$$

Now the boiler and superheater energy loads can be determined, and after an energy balance calculation, the boiler inlet temperature can be determined. The inlet temperature of the boiler can estimated in a similar manner to the exit temperature of the heat recovery preheater. From this, the LMTD for both the superheater and the boiler can be calculated. Finally, the required heat transfer areas for both heat exchangers are calculated from knowledge of the heat transfer coefficient, heat load, and LMTD.

$$
\begin{aligned}
& Q_{b}=17,929 M_{s t} \\
& Q_{s}=\left(\hat{h}_{W}\left(T_{\text {specified }}\right)-2134.8\right) M_{s t} \\
& T_{\text {guess }}=T_{H P, i}\left(1-\frac{Q_{H P}}{E_{H P, i}}\right) \\
& E_{\text {guess }}=\sum_{k=1}^{11} \hat{h}_{k}\left(T_{\text {guess }}\right) M_{k} \\
& T_{\text {bi,i }}=-Q_{s} \frac{T_{H P, o}-T_{\text {guess }}}{E_{H P, o}-E_{\text {guess }}}+T_{H P, 0}
\end{aligned}
$$

The log mean temperature differences for the boiler and superheater are based on the inlet and outlet temperatures of the two heat exchangers. The required heat transfer surface area for each is calculated based on the heat load, the log mean temperature difference, and the universal heat transfer coefficient. The values for the heat transfer coefficients are adopted from the Monsanto estimate. 


$$
\begin{aligned}
& \operatorname{LMTD}_{s}=\frac{\left(T_{H P, o}-T_{\text {specified }}\right)-\left(T_{b, i}-338\right)}{\ln \left(\frac{T_{H P, o}-T_{\text {specified }}}{T_{b, i}-338}\right)} \\
& \operatorname{LMTD}_{b}=\frac{\left(T_{b, i}-338\right)-(506-226)}{\ln \left(\frac{T_{b, i}-338}{506-226}\right)} \\
& A_{s}=\frac{Q_{s}}{6 \operatorname{LMT}_{s}} \\
& A_{b}=\frac{Q_{b}}{15 L M T D_{b}}
\end{aligned}
$$

The off-gas enters the cooling and humidification tower at a temperature of $506^{\circ} \mathrm{F}$ and leaves at $169^{\circ} \mathrm{F}$. It is assumed that about 30 percent of the water vapor is removed based on the Monsanto design. Cooling is effected by the circulation of a weak acid stream through the cooling tower. The mass flow of this stream is calculated by an energy balance. The constant 324.6 is amount of energy needed to raise the temperature of the weak acid from $163^{\circ} \mathrm{F}$ to $181^{\circ} \mathrm{F}$. The constants 840.6 and 17,813 are the enthalpy and heat of vaporization at $181^{\circ} \mathrm{F}$.

$$
\begin{aligned}
& \mathrm{E}_{\mathrm{GC}, \mathrm{o}}=\sum_{\mathrm{k}=1}^{11} \hat{h}_{\mathrm{k}}(169) \mathrm{M}_{\mathrm{k}}-0.3 \hat{h}_{\mathrm{W}}(169) \mathrm{M}_{\mathrm{W}, \mathrm{HP}, \mathrm{i}} \\
& \mathrm{M}_{\mathrm{WA}}=\frac{\mathrm{E}_{\mathrm{GC}, \mathrm{i}}-\mathrm{E}_{\mathrm{GC}, \mathrm{O}}+0.3\left(\hat{h}_{\mathrm{W}}\left(\mathrm{T}_{\mathrm{GC}, \mathrm{i}}\right)-840.6+17,813\right) \mathrm{M}_{\mathrm{W}, \mathrm{HP}, \mathrm{i}}}{324.6}
\end{aligned}
$$

The electricity usage for the main and dilution compressors, as well as, the pumps used for the strong,weak, and product acid pumps can be determined. The pressure drops across the main and diution compressors are $116^{\prime \prime}$ and $67^{\prime \prime}$ of water respectively.

$$
\begin{aligned}
& \mathrm{EC}_{\mathrm{BF}}=\left(\frac{1545 \mathrm{M}_{\mathrm{BF}}}{0.75^{*} 60^{*} 44240}\right)\left(\frac{1.4}{1.4-1}\right)\left[\left(\frac{14.687 \mp 3.612 \mathrm{e}^{-2 * 67}}{14.687}\right)^{\frac{1.4-1}{1.4}}-1\right](80+460) \\
& \mathrm{EC}_{\mathrm{MC}}=\left(\frac{1545 \mathrm{M}_{\mathrm{D}, \mathrm{o}}}{0.75^{*} 60^{*} 44240}\right)\left(\frac{1.4}{1.4-1}\right)\left[\left(\frac{14.687+3.612 \mathrm{e}^{-2 * 167}}{14.687+3.612 \mathrm{e}^{-2 * 51}}\right)^{\frac{1.4-1}{1.4}}-1\right](120+460)
\end{aligned}
$$

The total acid produced can be determined along with the energy consumption of the pumps. The pressure drops for the strong, weak, and product acid pumps are 80 feet of water, $120 \mathrm{psi}$, 
and 80 psi respectively. The efficiency for the strong and weak acid pumps are $80 \%$, while the product pump is much smaller and has an efficiency of $70 \%$. The specific gravity for sulfuric acid greater than $95 \%$ is 1.83 , while the specific gravity for weak acid is assumed to be 1 . The specific gravity for the product acid at $93 \%$ concentration, is estimated to be 1.77 , which equals $1.83 * .93$ $+1 * 0.07$. The energy needed for the weak acid pump is based on the molar flow rate of weak acid. The strong acid system which supplies acid to the drying, interpass, and final towers has three pumps. Therefore the energy usage is based on scaling the total flow rate for these pumps on the sulfuric acid produced. In the Monsanto design, 3501 gallons per minute of strong acid is pumped against a head of 80 feet of water for 17.3 tons per hour of acid produced.

$$
\begin{aligned}
m_{\mathrm{acid}}= & 0.995\left(\mathrm{M}_{\mathrm{SD}, \mathrm{R}, \mathrm{o}}+\mathrm{M}_{\mathrm{CS}, \mathrm{R}, \mathrm{o}}+\mathrm{M}_{\mathrm{HS}, \mathrm{R}, \mathrm{o}}+2 \mathrm{M}_{\mathrm{S}, \mathrm{R}, \mathrm{o}}\right) * 98 \mathrm{lbm} / \mathrm{lbmole} \\
& / 2000 \text { tons } / \mathrm{lbm}
\end{aligned}
$$

$$
\mathrm{EC}_{\mathrm{WA}}=\frac{120 \frac{\mathrm{lbf}}{\mathrm{in}^{2}} * 18 \frac{\mathrm{lbm}}{\mathrm{lbmole}} * 144 \frac{\mathrm{in}^{2}}{\mathrm{ft}^{2}} \mathrm{M}_{\mathrm{WA}}}{44,240 \frac{\mathrm{ft}-\mathrm{lbf} / \mathrm{min}}{\mathrm{kW}} * 7.4805 \frac{\mathrm{gal}}{\mathrm{ft}^{3}} * 60 \frac{\mathrm{min}}{\mathrm{hr}} * 8.33 \frac{\mathrm{lbm}}{\mathrm{gal}} * 0.80}
$$

which simplifies to

$$
\begin{aligned}
\mathrm{EC}_{\mathrm{WA}} & =\frac{120 \frac{\mathrm{lbf}}{\mathrm{in}^{2}} \mathrm{M}_{\mathrm{WA}}}{63,813 \frac{\mathrm{lbmole} / \mathrm{hr} * \mathrm{lbf} / \mathrm{in}^{2}}{\mathrm{~kW}} * 0.80} \\
\mathrm{EC}_{\mathrm{SS}} & =\frac{\left(\frac{3501 \frac{\mathrm{gal}}{\mathrm{min}}}{17.3 \frac{\mathrm{tons}}{\mathrm{hr}}}\right) 80 \mathrm{ft} * 61.2 \frac{\mathrm{lbm}}{\mathrm{ft}^{3}} * 32.174 \frac{\mathrm{ft}}{\mathrm{sec}^{2}} * 1.83 \mathrm{~m}_{\mathrm{acid}}}{7.4805 \frac{\mathrm{gal}}{\mathrm{ft}^{3}} * 32.174 \frac{\mathrm{lbm}-\mathrm{ft}}{\mathrm{lbf}-\mathrm{sec}^{2}} * 44,240 \frac{\mathrm{ft}-\mathrm{lbf} / \mathrm{min}}{\mathrm{kW}} * 0.80}
\end{aligned}
$$

which simplifies to

$$
\begin{aligned}
& \mathrm{EC}_{\mathrm{SS}}=\frac{202.4 \frac{\mathrm{gal} / \mathrm{min}}{\mathrm{tons} / \mathrm{hr}} * 80 \mathrm{ft} \mathrm{m}_{\mathrm{acid}}}{2955 \frac{\mathrm{gal} / \mathrm{min} * \mathrm{ft}}{\mathrm{kW}} * 0.80} \\
& \mathrm{EC}_{\mathrm{PA}}=\frac{2000 \frac{\mathrm{lbm}}{\mathrm{ton}} * 144 \frac{\mathrm{in}^{2}}{\mathrm{ft}^{2}} * 80 \frac{\mathrm{lbf}}{\mathrm{in}^{2}} \mathrm{~m}_{\mathrm{acid}}}{60 \frac{\mathrm{min}}{\mathrm{hr}} * 8.33 \frac{\mathrm{lbm}}{\mathrm{gal}} * 7.4805 \frac{\mathrm{gal}}{\mathrm{ft}^{3}} * 44,240 \frac{\mathrm{ft}-\mathrm{lbf} / \mathrm{min}}{\mathrm{kW}} * 1.77 * 0.70}
\end{aligned}
$$


which simplifies to

$$
\mathrm{EC}_{\mathrm{PA}}=\frac{80 \frac{\mathrm{lbf}}{\mathrm{in}^{2}} \mathrm{~m}_{\mathrm{acid}}}{1017 \frac{\text { tons } / \mathrm{hr} \mathrm{lbf} / \mathrm{in}^{2}}{\mathrm{~kW}} * 0.70}
$$

The totai energy consumed is the sum of the inlet, gas burner, dilution air, and main compressor plus the weak, strong, and product acid pumps. The equivalent electric power of the steam produced is calculated by assuming an $88 \%$ efficient boiler and the heat rate specified by the main power plant.

$$
\begin{aligned}
& \mathrm{EC}_{\text {total }}=\mathrm{EC}_{\mathrm{IC}}+\mathrm{EC}_{\mathrm{GB}}+\mathrm{EC}_{\mathrm{BF}}+\mathrm{EC}_{\mathrm{MC}}+\mathrm{EC}_{\mathrm{WA}}+\mathrm{EC}_{\mathrm{SS}}+\mathrm{EC}_{\mathrm{PA}} \\
& \mathrm{EC}_{\mathrm{st}}=\frac{\mathrm{E}_{\mathrm{PH}, \mathrm{o}}-\mathrm{E}_{\mathrm{GC}, \mathrm{i}}}{0.88 \mathrm{HR}}
\end{aligned}
$$

\subsection{Economic Model}

The cost estimate for the sulfuric acid plant is based on physical parameters that affect the cost of the equipment in the plant. An experimental scaling factor of 0.6 is assumed and all the capital cost are in mid-83 dollars, except for the inlet compressor and gas burner which are mid- 82 dollars. All costs may later be adjusted to a current basis using appropriate cost-escalators included in the IEC model.

\subsubsection{Capital Cost}

The cost of the inlet compressor depends on the pressure drop and the inlet gas flow rate. The cost is split by pressure drop since the capital cost of blowers and compressors increase with increasing pressure. The cost estimates came from the NOXSO chapter in the EPRI Economic Evaluation of FGD System [6]. For both estimates, it is assumed that there are two operating and one spare. The algorithm is:

$$
\begin{aligned}
& \text { if } \mathrm{P}_{\mathrm{R}, \mathrm{O}}<47^{\prime \prime} \text { of water } \\
& \qquad \mathrm{DCC}_{\mathrm{IC}}=\$ 1.04 \mathrm{e}^{6}\left(\frac{\mathrm{G}_{\mathrm{R}, 0}}{35,000 \mathrm{ft}^{3} / \mathrm{min}}\right)^{0.6} \frac{\mathrm{C}_{\mathrm{idx}}}{314}
\end{aligned}
$$




$$
\begin{aligned}
& \text { else if } 47<=P_{R, 0}<95 \\
& \text { DCC }_{I C}=\$ 5.64 \mathrm{e}^{6}\left(\frac{G_{R, 0}}{1.80 \mathrm{e}^{6} \mathrm{ft}^{3} / \mathrm{min}}\right)^{0.6} \frac{\mathrm{C}_{\mathrm{idx}}}{314}
\end{aligned}
$$

The capital gas of the gas burner is also taken from reference [6]. It is assumed that there are two operating and one spare, and that the cost includes the cost of the combustion air compressor.

$$
\mathrm{DCC}_{\mathrm{GB}}=\$ 7.07 \mathrm{e}^{5}\left(\frac{\mathrm{G}_{\mathrm{IC}, \mathrm{o}}}{68,000 \mathrm{ft}^{3} / \mathrm{min}}\right)^{0.6} \frac{\mathrm{C}_{\mathrm{idx}}}{314}
$$

The heat recovery preheater cost is scaled to the Monsanto cost estimate of $\$ 29,000$ for a heat exchanger with an area of 1100 square feet. The cost of the boiler is based on an estimated cost of $\$ 53,000$ for a heat exchanger with 350 square feet of heat exchange area. The cost of the superheater is scaled from the estimate of $\$ 80,000$ for a heat exchanger with an area of 50 square feet.

$$
\begin{aligned}
& \mathrm{DCC}_{\mathrm{HP}}=\$ 29,000\left(\frac{\mathrm{A}_{\mathrm{HP}}}{1,100 \mathrm{ft}^{2}}\right)^{0.6} \frac{\mathrm{C}_{\mathrm{idx}}}{316.9} \\
& \mathrm{DCC}_{\mathrm{b}}=\$ 53,000\left(\frac{\mathrm{A}_{\mathrm{b}}}{350 \mathrm{ft}^{2}}\right)^{0.6} \frac{\mathrm{C}_{\mathrm{idx}}}{316.9} \\
& \mathrm{DCC}_{\mathrm{s}}=\$ 80,000\left(\frac{\mathrm{A}_{\mathrm{s}}}{50 \mathrm{ft}^{2}}\right)^{0.6} \frac{\mathrm{C}_{\mathrm{idx}}}{316.9}
\end{aligned}
$$

The gas humidification and cooling tower cost estimate is based on the Monsanto estimate of $\$ 367,000$ for a gas stream of $1063 \mathrm{lbmole} / \mathrm{hr}$. The cost of the tower is scaled to the off-gas flow $\mathrm{M}_{\mathrm{GC}, \mathrm{i}}$ entering the sulfuric acid plant.

$$
\operatorname{DCC}_{\mathrm{GC}}=\$ 367,000\left(\frac{\mathrm{M}_{\mathrm{GC}}}{1,063 \mathrm{lbmole} / \mathrm{hr}}\right)^{0.6} \frac{\mathrm{C}_{\mathrm{idx}}}{316.9}
$$

The weak acid system is associated with the gas humidification and cooling tower. The cost of this system is proportional to the flow rate of weak acid, $M_{W A}$, required to achieve the necessary cooling in the tower.

$$
D_{C C} C_{\mathrm{WA}}=\$ 39,000\left(\frac{\mathrm{M}_{\mathrm{WA}}}{19,250 \mathrm{lbmole} / \mathrm{hr}}\right)^{0.6} \frac{\mathrm{C}_{\mathrm{idx}}}{316.9}
$$

The drying tower is sized to accommodate the inlet gas stream consisting of the regenerator 
off-gas and dilution air, $M_{D, i}$. Monsanto estimated a cost of $\$ 636,000$ for a tower that handles $5325 \mathrm{lbmole} / \mathrm{hr}$ of gas.

$$
\operatorname{DCC}_{\mathrm{D}}=\$ 636,000\left(\frac{\mathrm{M}_{\mathrm{D}, \mathrm{i}}}{5,325 \mathrm{lbmole} / \mathrm{hr}}\right)^{0.6} \frac{\mathrm{C}_{\mathrm{idx}}}{316.9}
$$

The blower and filter are required to pump and clean the dilution air mass flow, $\mathrm{M}_{\mathrm{BF}}$, and are sized accordingly. Monsanto estimated the cost of these components based on a dilution air inlet flow of $4407 \mathrm{lbmole} / \mathrm{hr}$.

$$
\operatorname{DCC}_{\mathrm{BF}}=\$ 518,000\left(\frac{\mathrm{M}_{\mathrm{BF}}}{4,407 \mathrm{lbmole} / \mathrm{hr}}\right)^{0.6} \frac{\mathrm{C}_{\mathrm{idx}}}{316.9}
$$

The contact section of the sulfuric acid plant includes the inter-pass heat exchangers and the catalytic converter. The total cost of this part of the system was estimated by Monsanto to be $\$ 2,681,000$. The cost of this part of the plant is scaled to the gas flow exiting the drying tower.

$$
\mathrm{DCC}_{\mathrm{CS}}=\$ 2,681,000\left(\frac{\mathrm{M}_{\mathrm{D}, \mathrm{o}}}{4,854 \mathrm{lbmole} / \mathrm{hr}}\right)^{0.6} \frac{\mathrm{C}_{\mathrm{idx}}}{316.9}
$$

The cost for the interpass and final towers and their associated equipment was estimated to be $\$ 988,000$. This cost is scaled to the gas stream $\mathrm{M}_{23}$.

$$
\mathrm{DCC}_{\mathrm{T}}=\$ 988,000\left(\frac{\mathrm{M}_{23}}{4,685 \mathrm{lbmole} / \mathrm{hr}}\right)^{0.6} \frac{\mathrm{C}_{\mathrm{idx}}}{316.9}
$$

The strong acid system is proportional in size to the amount of sulfur in the off-gas stream. The cost of the effluent stripper is assumed to be proportional to the off-gas flow rate.

$$
\begin{aligned}
D_{C C} & =\$ 739,000\left(\frac{M_{S D, H P, i}+M_{C S, H P, i}+M_{H S, H P, i}+2 M_{S, H P, i}}{354 \text { lbmole/hr }}\right)^{0.6} \frac{C_{i d x}}{316.9} \\
D_{C C C} & =\$ 70,000\left(\frac{M_{G C, i}}{1,063 \text { lbmole/hr }}\right)^{0.6} \frac{C_{i d x}}{316.9}
\end{aligned}
$$

The total direct cost of the sulfuric acid plant is the sum of the individual equipment direct capital costs. The indirect capital cost, not including AFUDC, is estimated to be $27.5 \%, 41.9 \%$, and $8.1 \%$ of the total direct cost for the labor and general field cost, home office cost, and contingency respectively.

$$
\mathrm{DCC}_{\text {total }}=\sum_{k=1}^{13} \mathrm{DCC}_{\mathrm{k}}
$$




$$
\mathrm{TCC}_{\text {acid }}=(1+0.275+0.419+0.081) \mathrm{DCC}_{\text {total }}=1.776 \mathrm{DCC}_{\text {total }}
$$

\subsubsection{Operating and Maintenance Costs}

The non-utility operating costs of an acid plant consist of the operating, maintenance, and administration labor, plus maintenance material, catalyst makeup, marketing, and shipping cost. The labor costs, and makeup requirements are estimated from letters with Monsanto [4,5]. The maintenance personal are assumed to only work $1 / 3$ of the total number of hours in a year; whereas, it is assumed that 2 operators are always working around the clock. Acid plants of this size require 2 operators per shift, with 2 full time maintenance people. The administration and support labor cost is estimated to be $30 \%$ of the operating and maintenance labor cost.

$$
\begin{aligned}
& O C_{\text {oper }}=2 \text { persons } * 19.70 \$ / \mathrm{hr} * 8766 \mathrm{hrs} / \mathrm{yr} * \mathrm{C}_{\mathrm{idx}} / 325.3 \\
& O C_{\text {maint-labor }}=2 \text { persons } * 19.70 \$ / \mathrm{hr} * 8766 \mathrm{hrs} / \mathrm{yr} / 3 * \mathrm{C}_{\mathrm{idx}} / 325.3 \\
& O C_{\mathrm{admin}}=0.30 *\left(O C_{\mathrm{oper}}+O \mathrm{OC}_{\text {maint-labor }}\right)
\end{aligned}
$$

The maintenance material costs is estimated as a fraction of the direct capital cost. The fraction is $0.9 \%$. The makeup of the catalyst is approximately $2 \%$ per year and the converter requires approximately $\$ 35.2 \mathrm{per} \mathrm{lbmole} / \mathrm{hr}$ of gas flow (1985\$) [5]. The marketing and shipping cost are estimated to be $10 \%$ of the sulfuric acid credit [11]. Sulfuric acid is assumed to sell for $\$ 50$ /ton (1985\$). [11].

$$
\begin{aligned}
& \mathrm{OC}_{\text {maint-matl }}=0.009 * \mathrm{DCC}_{\text {total }} \\
& \mathrm{OC}_{\text {makeup }}=0.02 * 35.285 \$ / 1 \mathrm{bmole} / \mathrm{hr} * \mathrm{M}_{6} * \mathrm{C}_{\mathrm{idx}} / 325.3 \\
& \mathrm{OC}_{\text {credit }}=5085 \$ / \text { ton } * \mathrm{CF} * 8766 * \mathrm{~m}_{\text {acid }} * \mathrm{C}_{\mathrm{idx}} / 325.3 \\
& \mathrm{OC}_{\text {marketing }}=0.1 * \mathrm{OC}_{\text {credit }} \\
& \mathrm{OC}_{\text {total }}=O \mathrm{OC}_{\text {oper }}+\mathrm{OC}_{\text {maint-labor }}+\mathrm{OC}_{\mathrm{admin}}+\mathrm{OC}_{\text {main-mater }}+O C_{\text {makeup }} \\
& \quad+O C_{\text {marketing }}-\mathrm{OC}_{\text {credit }}
\end{aligned}
$$




\subsection{Numerical Example}

This section contains a numerical example of the sulfuric acid plant model presented in the previous sections. The input parameters and their values necessary to run the model are given in Table 1. The model will be illustrated by using a gas stream with a large quantity of combustible gases, which requires the use of the gas burner. The gas stream is not from any particular report or FGD process. The composition consist of all the species with which this model has been designed for except for nitrogen and oxygen. ${ }^{3}$ The pressure exiting the regenerator in the FGD process is 28 " of water; therefore, the inlet compressor is required to raise the pressure to 97 " of water.

Since the pressure of the regenerator off-gas is less than 97 " of water, the inlet compressor is needed. Equations 3.1, 3.2, 3.3, and 3.4 are used to calculate the temperature exiting the inlet compressor, gas flow rate in actual cubic feet per minute, and electricity consumption of the compressor.

$$
\begin{aligned}
& \mathrm{T}_{I C, \mathrm{O}}=\left(\mathrm{T}_{\mathrm{R}, \mathrm{O}}+460\right)\left(\frac{14.687+3.612 \mathrm{e}^{-2 * 97}}{14.687+3.612 \mathrm{e}^{-2} \mathrm{P}_{\mathrm{R}, \mathrm{O}}}\right)^{\frac{1.4-1}{1.4}}-460 \\
& \mathrm{~T}_{1 C, \mathrm{i}}=(550+460)\left(\frac{14.687+3.612 \mathrm{~d}^{-2} * 97}{14.687+3.612 \mathrm{e}^{-2 * 28}}\right)^{\frac{1.4-1}{1.4}}-460 \\
& \mathrm{~T}_{\mathrm{IC}, \mathrm{i}}=958.5^{\circ} \mathrm{F} \\
& \mathrm{G}_{\mathrm{IC}, \mathrm{i}}=\frac{1545 \mathrm{M}_{\mathrm{R}, \mathrm{O}}\left(\mathrm{T}_{\mathrm{R}, \mathrm{o}}+460\right)}{60 * 144\left(14.687+3.612 \mathrm{e}^{-2} \mathrm{P}_{\mathrm{R}, \mathrm{O}}\right)} \\
& \mathrm{G}_{\mathrm{IC,i}}=\frac{1545 * 1,568 *(550+460)}{60 * 144\left(14.687+3.612 \mathrm{e}^{-2 * 28}\right)} \\
& \mathrm{G}_{\mathrm{IC}, \mathrm{i}}=24,290 \mathrm{acfm} \\
& G_{I C, 0}=\frac{1545 M_{R, 0}\left(T_{I C, o}+460\right)}{60 * 144\left(14.687+3.612 \mathrm{e}^{-2 * 97}\right)}
\end{aligned}
$$

3 There are two reasons for not including oxygen and nitrogen in the gas stream for the numerical example. Since there are products of incomplete oxidation in this particular $g$ stream, it is not likely to contain oxygen. Nitrogen could have been added to the gas; however, any nitrogen available would probably have been added with air to completely oxidize the gas in the regenerator. 
Table 1: Input Parameters for Sulfuric Acid Plant Numerical Example

\begin{tabular}{lllr}
\hline Input Parameter & Sample Value & Input Parameter & Sample Value \\
\hline $\mathrm{T}_{\mathrm{R}, \mathrm{O}}$ & $900^{\circ} \mathrm{F}$ & $\mathrm{M}_{\mathrm{M}, \mathrm{R}, \mathrm{O}}$ & $10 \mathrm{lbm} . \mathrm{ole} / \mathrm{hr}$ \\
$\mathrm{P}_{\mathrm{R}, \mathrm{O}}$ & $28^{\prime \prime}$ of water & $\mathrm{M}_{\mathrm{N}, \mathrm{R}, \mathrm{O}}$ & $0 \mathrm{lbmole} / \mathrm{hr}$ \\
$\mathrm{T}_{\text {specified }}$ & $550^{\circ} \mathrm{F}$ & $\mathrm{M}_{\mathrm{O}, \mathrm{R}, \mathrm{O}}$ & $0 \mathrm{lbmole} / \mathrm{hr}$ \\
$\mathrm{M}_{\mathrm{CD}, \mathrm{R}, \mathrm{O}}$ & $500 \mathrm{lbmole} / \mathrm{hr}$ & $\mathrm{M}_{\mathrm{S}, \mathrm{R}, \mathrm{O}}$ & $41 \mathrm{lbmole} / \mathrm{hr}$ \\
$\mathrm{M}_{\mathrm{CO}, \mathrm{R}, \mathrm{O}}$ & $50 \mathrm{lbmole} / \mathrm{hr}$ & $\mathrm{M}_{\mathrm{SD}, \mathrm{R}, \mathrm{O}}$ & $200 \mathrm{lbmole} / \mathrm{hr}$ \\
$\mathrm{M}_{\mathrm{COS}, \mathrm{R}, \mathrm{O}}$ & $17 \mathrm{lbmole} / \mathrm{hr}$ & $\mathrm{M}_{\mathrm{W}, \mathrm{R}, \mathrm{O}}$ & $500 \mathrm{lbmole} / \mathrm{hr}$ \\
$\mathrm{M}_{\mathrm{H}, \mathrm{R}, \mathrm{O}}$ & $100 \mathrm{lbmole} / \mathrm{hr}$ & $\mathrm{M}_{\mathrm{R}, \mathrm{O}}$ & $1,568 \mathrm{lbmole} / \mathrm{hr}$ \\
$\mathrm{M}_{\mathrm{HS}, \mathrm{R}, \mathrm{O}}$ & $150 \mathrm{lbmole} / \mathrm{hr}$ & & \\
\hline
\end{tabular}

$$
\begin{aligned}
& \mathrm{G}_{\mathrm{IC}, \mathrm{o}}=\frac{1,545^{*} 1,568 *(958.54+460)}{60 * 144 *\left(14.687+3.612 \mathrm{e}^{-2 * 97)}\right.} \\
& \mathrm{G}_{\mathrm{IC}, \mathrm{o}}=21,865 \mathrm{acfm}
\end{aligned}
$$

$$
\text { if } \begin{aligned}
\mathrm{P}_{\mathrm{R}, \mathrm{O}} & <47 \text { then } \\
\text { EC } & \\
\mathrm{IC} & =\left(\frac{1545 \mathrm{M}_{\mathrm{R}, 0}}{0.75^{*} 60 * 44,240}\right)\left(\frac{1.4}{1.4-1}\right)\left[\left(\frac{14.687+3.612 \mathrm{e}^{-2 * 97}}{14.687+3.612 \mathrm{e}^{-2} \mathrm{P}_{\mathrm{R}, \mathrm{O}}}\right)^{\frac{1.4-1}{1.4}}-1\right]\left(\mathrm{T}_{\mathrm{R}, \mathrm{O}}+460\right)
\end{aligned}
$$

else $\mathrm{EC}_{\mathrm{IC}}=1.38 \mathrm{e}^{-4} \mathrm{G}_{\mathrm{IC}, \mathrm{i}}\left(97-\mathrm{P}_{\mathrm{R}, \mathrm{o}}\right)$

Since $28^{\prime \prime}$ is less than $97^{\prime \prime}$

$$
\begin{aligned}
& \mathrm{EC}_{\mathrm{IC}}=\left(\frac{1,545 * 1,568}{0.75 * 60 * 44,240}\right)\left(\frac{1.4}{1.4-1}\right)\left[\left(\frac{14.687+3.612 \mathrm{e}^{-2 * 97}}{14.687+3.612 \mathrm{e}^{-2 * 28}}\right)^{\frac{1.4-1}{1.4}}-1\right]\left(\mathrm{T}_{\mathrm{R}, \mathrm{O}}+460\right) \\
& \mathrm{EC}_{\mathrm{IC}}=249.3 \mathrm{~kW}
\end{aligned}
$$

The gas burner is used since the inlet gas contains a lot of combustible gases. The algorithm of the gas burner divides it into two parts, see Figure 3-3. The first part determines the amount of energy released by burning the combustible gases. This is used to determine the total energy flow exiting the first part of the gas burner, and the composition of the outlet gas. The air needed for combustion and its temperature are calculated first.

$$
\mathrm{M}_{\mathrm{O}, \mathrm{c}, 1}=2 \mathrm{M}_{\mathrm{M}, \mathrm{R}, \mathrm{o}}+0.5 \mathrm{M}_{\mathrm{H}, \mathrm{R}, \mathrm{o}}+0.5 \mathrm{M}_{\mathrm{CM}, \mathrm{R}, \mathrm{o}}+1.5 \mathrm{M}_{\mathrm{CS}, \mathrm{R}, \mathrm{o}}+1.5 \mathrm{M}_{\mathrm{HS}, \mathrm{R}, \mathrm{o}}+2 \mathrm{M}_{\mathrm{S}, \mathrm{R}, \mathrm{O}}
$$




$$
\begin{aligned}
& \mathrm{M}_{\mathrm{O}, \mathrm{c}, 1}=2 * 10+0.5 * 100+0.5 * 50+1.5 * 17+1.5 * 150+2 * 41=427.5 \mathrm{lbmole} / \mathrm{hr} \\
& \text { since } 1.05 * 427.5>0 \\
& \quad \mathrm{M}_{\mathrm{O}, \mathrm{c}}=1.05 * 427.5-0=448.9 \mathrm{lbmole} / \mathrm{hr} \\
& \mathrm{M}_{\mathrm{N}, \mathrm{c}}=3.76 \mathrm{M}_{\mathrm{O}, \mathrm{c}}=3.76 * 448.88=1,688 \mathrm{lbmole} / \mathrm{hr} \\
& \mathrm{M}_{\mathrm{W}, \mathrm{c}}=1.611^{*} 0.018(448.88+1,687.77)=61.96 \mathrm{lbmole} / \mathrm{hr} \\
& \quad \vdots \\
& \mathrm{T}_{\mathrm{c}}=(80+460)\left(\frac{14.687+3.612 \mathrm{e}^{-2 * 97}}{14.687}\right)^{\frac{1.4-1}{1.4}}-460 \\
& \mathrm{~T}_{\mathrm{c}}=114.1^{\circ} \mathrm{F}
\end{aligned}
$$

Now the exhaust gas from the first part and the energy released are calculated.

$$
\begin{aligned}
& \mathrm{M}_{\mathrm{CO}, \mathrm{GB}, 1}=\mathrm{M}_{\mathrm{COS}, \mathrm{GB}, 1}=\mathrm{M}_{\mathrm{H}, \mathrm{GB}, 1}=\mathrm{M}_{\mathrm{HS}, \mathrm{GB}, 1}=\mathrm{M}_{\mathrm{M}, \mathrm{GB}, 1}=\mathrm{M}_{\mathrm{S}, \mathrm{GB}, 1}=0 \\
& M_{S D, G B, 1}=M_{S D, R, o}+M_{C S, R, o}+M_{H S, R, o}+2 M_{S, R, o} \\
& \mathrm{M}_{\mathrm{SD}, \mathrm{GB}, 1}=200+17+150+2 * 41=449 \mathrm{lbmole} / \mathrm{hr} \\
& M_{W, G B, 1}=M_{W, R, o}+M_{W, c}+2 M_{M, R, o}+M_{H, R, o}+M_{H S, R, o} \\
& \mathrm{M}_{\mathrm{W}, \mathrm{GB}, 1}=500+61.96+2 * 10+100+150=832.0 \mathrm{lbmole} / \mathrm{hr} \\
& \mathrm{M}_{\mathrm{CD}, \mathrm{GB}, 1}=\mathrm{M}_{\mathrm{CD}, \mathrm{R}, \mathrm{O}}+\mathrm{M}_{\mathrm{M}, \mathrm{R}, \mathrm{O}}+\mathrm{M}_{\mathrm{CM}, \mathrm{R}, \mathrm{o}}+\mathrm{M}_{\mathrm{CS}, \mathrm{R}, \mathrm{o}} \\
& \mathrm{M}_{\mathrm{CD}, \mathrm{GB}, 1}=500+10+50+17=577 \mathrm{lbmole} / \mathrm{hr} \\
& \mathrm{M}_{\mathrm{N}, \mathrm{GB}, 1}=\mathrm{M}_{\mathrm{N}, \mathrm{R}, \mathrm{o}}+\mathrm{M}_{\mathrm{W}, \mathrm{c}} \\
& \mathrm{M}_{\mathrm{N}, \mathrm{GB}, 1}=0+1,688=1,688 \mathrm{lbmole} / \mathrm{hr} \\
& \text { since } 0>1.05 * 427.5 \text { is false } \\
& \mathrm{M}_{\mathrm{O}, \mathrm{GB}, 1}=0.05 \mathrm{M}_{\mathrm{O}, \mathrm{c}, 1}=0.05 * 417.5=21.38 \\
& \Delta \mathrm{H}_{\mathrm{GB}}=345,200 \mathrm{M}_{\mathrm{M}}+104,000 \mathrm{M}_{\mathrm{H}}+121,700 \mathrm{M}_{\mathrm{CM}}+255,400 \mathrm{M}_{\mathrm{S}}+ \\
& 222,900 \mathrm{M}_{\mathrm{HS}}+236,000 \mathrm{M}_{\mathrm{CS}} \\
& \Delta \mathrm{HGB}_{\mathrm{G}}=345,200 * 10+104,000 * 100+121,700 * 50+255,400 * 41+ \\
& 222,900 * 150+236,000 * 17 \\
& \Delta \mathrm{HGB}=67.86 \mathrm{e}^{6} \mathrm{Btu} / \mathrm{hr}
\end{aligned}
$$

The total energy exiting the first part of the gas burner is calculated next, along with the energy flow rates of the exhaust gases at two estimated temperatures $2000^{\circ} \mathrm{F}$ and $958.54^{\circ} \mathrm{F}$. Then the energy flow exiting the first part is compared to the energy flow rate of the exhaust gas, if it is 
greater than additional air is needed to cool the gas burner. Then the total volumetric flow rate of the combustion gas is calculated along with the electricity consumed by the compressor for the combustion air.

$$
\begin{aligned}
& \mathrm{E}_{\mathrm{GB}, \mathrm{i}}=\sum_{\mathrm{k}=1}^{11} \hat{\mathrm{h}}_{\mathrm{k}}\left(\mathrm{T}_{\mathrm{GB}, \mathrm{i}}\right) \mathrm{M}_{\mathrm{GB}, \mathrm{i}}=\sum_{\mathrm{k}=1}^{11} \hat{\mathrm{h}}_{\mathrm{k}}(958.54) \mathrm{M}_{\mathrm{GB}, \mathrm{i}} \\
& \mathrm{E}_{\mathrm{GB}, \mathrm{i}}=9,567 * 500+6,414 * 50+10.34 \mathrm{e}^{3 * 17}+6,166 * 100+7,950 * 150+ \\
& 10,33 \mathrm{e}^{3 *} * 10+6,359 * 0+7.426 * 41+9,833 * 200+7,576 * 500 \\
& \mathrm{E}_{\mathrm{GB}, \mathrm{i}}=13.25 \mathrm{e}^{6} \mathrm{Btu} / \mathrm{hr} \\
& E_{c}=\hat{h}_{O}\left(T_{c}\right) M_{O, c}+\hat{h}_{N}\left(T_{c}\right) M_{N, c}+\hat{h}_{W, c}\left(T_{c}\right) M_{w, c} \\
& E_{c}=261.3 * 448.9+258.6 * 1,688+298.2 * 61.96=572.2 e^{3} \mathrm{Btu} / \mathrm{kr} \\
& \mathrm{E}_{\mathrm{GB}, \text { total }}=\mathrm{E}_{\mathrm{BG}, \mathrm{i}}+\mathrm{E}_{\mathrm{c}}+\Delta \mathrm{H}_{\mathrm{GB}} \\
& \mathrm{E}_{\mathrm{GB}, \text { total }}=13.25 \mathrm{e}^{6}+572.2 \mathrm{e}^{3}+67.86 \mathrm{e}^{6}=81.68 \mathrm{e}^{6} \\
& \mathrm{E}_{\mathrm{GB}, \max }=\sum_{\mathrm{j}=1}^{5} \hat{\mathrm{h}}_{\mathrm{j}}(2000) \mathrm{M}_{\mathrm{j}, 1}
\end{aligned}
$$

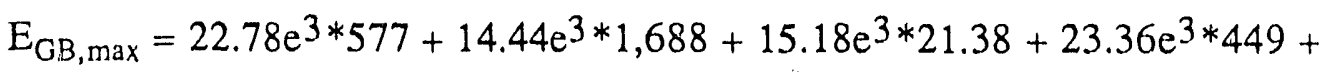

$$
\begin{aligned}
& 17.92 \mathrm{e}^{3 * 832.0} \\
& \mathrm{E}_{\mathrm{GB}, \max }=63.24 \mathrm{e}^{6} \mathrm{Btu} / \mathrm{hr} \\
& E_{G B, \min }=\sum_{j=1}^{5} \hat{h}_{j}\left(T_{G B, i}\right) M_{j, 1} \\
& \mathrm{E}_{\mathrm{GB}, \min }=9,569 * 577+6,359 * 1,688+6,640 * 21.38+9,833 * 449+ \\
& 7,576 * 832.0 \\
& \mathrm{E}_{\mathrm{GB}, \min }=27.11 \mathrm{e}^{6} \mathrm{Btu} / \mathrm{hr} \\
& \text { if } E_{G B, \text { total }}>E_{G B, \max } \text { then } \\
& \mathrm{M}_{\mathrm{O}, \mathrm{ex}}=\frac{\mathrm{E}_{\mathrm{GB}, \text { total }}-\mathrm{E}_{\mathrm{GB}, \max }}{15,180-\hat{\mathrm{h}}_{\mathrm{O}}\left(\mathrm{T}_{\mathrm{c}}\right)+3.76\left(14,440-\hat{\mathrm{h}}_{\mathrm{N}}\left(\mathrm{T}_{\mathrm{c}}\right)\right)+1.611 * 0.018^{*}\left(17,920-\hat{\mathrm{h}}_{\mathrm{W}}\left(\mathrm{T}_{\mathrm{c}}\right)\right)} \\
& \mathrm{T}_{\mathrm{GB}, \mathrm{O}}=2000
\end{aligned}
$$


else $\begin{aligned} M_{O, e x} & =0 \\ T_{G B, o} & =\frac{2000-T_{G B, 1}}{E_{G B, \max }-E_{G B, \min }}\left(E_{G B, \text { total }}-E_{G B, \min }\right)+T_{G B, i}\end{aligned}$

since $81.68 \mathrm{e}^{6}>63.24 \mathrm{e}^{6}$

$\mathrm{M}_{\mathrm{O}, \mathrm{ex}}=\frac{81.68 \mathrm{e}^{6}-63.24 \mathrm{e}^{6}}{(15,180-261.3)+3.76(14,440-258.6)+1.611 * 0.018 * 4.76(17,920-298.2)}$
$\mathrm{M}_{\mathrm{O}, \mathrm{ex}}=260.9 \mathrm{lbmole} / \mathrm{hr}$
$\mathrm{T}_{\mathrm{GB}, \mathrm{o}}=2000^{\circ} \mathrm{F}$
$\mathrm{M}_{\mathrm{N}, \mathrm{ex}}=3.76 \mathrm{M}_{\mathrm{O}, \mathrm{ex}}=3.76 * 260.9=981.1 \mathrm{lbmole} / \mathrm{hr}$
$\mathrm{M}_{\mathrm{W}, \mathrm{ex}}=1.611^{*} 0.018 * 4.76 \mathrm{M}_{\mathrm{O}, \mathrm{ex}}=1.611 * 0.018^{*} 4.76^{*} 260.9=36.02 \mathrm{lbmole} / \mathrm{hr}$
$\mathrm{M}_{\mathrm{c}, \text { total }}=\mathrm{M}_{\mathrm{O}, \mathrm{c}}+\mathrm{M}_{\mathrm{N}, \mathrm{c}}+\mathrm{M}_{\mathrm{W}, \mathrm{c}}+\mathrm{M}_{\mathrm{O}, \mathrm{ex}}+\mathrm{M}_{\mathrm{N}, \mathrm{ex}}+\mathrm{M}_{\mathrm{W}, \mathrm{cx}}$
$\mathrm{M}_{\mathrm{c}, \text { total }}=448.9+1,688+61.96+260.9+981.1+36.02=3,477 \mathrm{lbmole} / \mathrm{hr}$
$\mathrm{G}_{\mathrm{c}, \text { total }}=\frac{1,545 \mathrm{M}_{\mathrm{c}, \text { total }}(80+460)}{60^{*} 14.687 * 144}=\frac{1,545^{*} 3,477 *(80+460)}{60 * 14.687^{* 144}}=22,860 \mathrm{acfm}$
$\mathrm{EC}_{\mathrm{GB}}=\left(\frac{1545 \mathrm{M}_{\mathrm{c}, \text { total }}}{0.75 * 60^{*} 44,240}\right)\left(\frac{1.4}{1.4-1}\right)\left[\left(\frac{14.687+3.612 \mathrm{e}^{-2 * 97}}{14.687}\right)^{\frac{1.4-1}{1.4}}-1\right](80+460)$
$\mathrm{EC}_{\mathrm{GB}}=\left(\frac{1,545^{*} 3,477}{0.75 * 60^{*} 44,240}\right)\left(\frac{1.4}{1.4-1}\right)\left[\left(\frac{14.687+3.612 \mathrm{e}^{-2} * 97}{14.687}\right)^{\frac{1.4-1}{1.4}}-1\right](80+460)$
$\mathrm{EC}_{\mathrm{GB}}=321.8 \mathrm{~kW}$

Since the gas burner is used, the actual exhaust gas and volumetric gas flow rate needs to be calculated. It is important to note that the molar flow rate has tripled, while the volumetric flow rate has increased almost five times. Since the gas burner is located upstream of the superheater and boiler, the energy released in the gas burner can be partiaily recovered by the superheater and boiler.

$$
\begin{aligned}
& M_{C O, H P, i}=M_{C O S, H P, i}=M_{H, H P, i}=M_{H S, H P, i}=M_{M, H P, i}=M_{S, H P, i}=0 \mathrm{lbmole} / \mathrm{hr} \\
& M_{S D, H P, i}=M_{S D, G B, 1}=449 \mathrm{lbmole} / \mathrm{hr} \\
& M_{C D, H P, i}=M_{C D, G B, 1}=577 \mathrm{lbmole} / \mathrm{hr} \\
& M_{N, H P, i}=M_{N, G B, 1}+M_{N, e x}=1,688+981.1=2669 \mathrm{lbmole} / \mathrm{hr}
\end{aligned}
$$




$$
\begin{aligned}
& \mathrm{M}_{\mathrm{O}, \mathrm{HP}, \mathrm{i}}=\mathrm{M}_{\mathrm{O}, \mathrm{GB}, 1}+\mathrm{M}_{\mathrm{O}, \mathrm{ex}}=21.38+260.9=282.3 \mathrm{lbmole} / \mathrm{hr} \\
& \mathrm{M}_{\mathrm{W}, \mathrm{HP}, \mathrm{i}}=\mathrm{M}_{\mathrm{W}, \mathrm{GB}, 1}+\mathrm{M}_{\mathrm{W}, \mathrm{ex}}=832.0+36.02=868.0 \mathrm{lbmole} / \mathrm{hr} \\
& \mathrm{T}_{\mathrm{HP}, \mathrm{i}}=\mathrm{T}_{\mathrm{GB}, \mathrm{o}}=2000^{\circ} \mathrm{F} \\
& \mathrm{M}_{\mathrm{HP}, \mathrm{i}}=\sum_{\mathrm{k}=1}^{11} \mathrm{M}_{\mathrm{k}, \mathrm{HP}, \mathrm{i}}=577+2,669+282.3++449+868.0=4,845 \mathrm{lbmole} / \mathrm{hr} \\
& \mathrm{G}_{\mathrm{HP}, \mathrm{i}}=\frac{1,545 \mathrm{M}_{\mathrm{HP}, \mathrm{i}}\left(\mathrm{T}_{\mathrm{HP}, \mathrm{i}}+460\right)}{60^{*} 144 *\left(14.687+3.612 \mathrm{e}^{-2} * 97\right)}=\frac{1,545 * 4,845 *(2,000+460)}{60 * 144 *\left(14.687+3.612 \mathrm{e}^{-2 * 97)}\right.} \\
& \mathrm{G}_{\mathrm{HP}, \mathrm{i}}=117.2 \mathrm{e}^{3} \mathrm{acfm}
\end{aligned}
$$

The next step is to calculate the oxygen needed for the converter and the energy released in the first stage of the converter. The first first stage of the catalytic converter is divided into two parts to solve for the amount of dilution air. The first part burns any combustibles and converts above $70 \%$ of the $\mathrm{SO}_{2}$ to $\mathrm{SO}_{3}$.

$$
\begin{aligned}
& \mathrm{M}_{\mathrm{O}, \mathrm{CS}, 1}= 2 \mathrm{M}_{\mathrm{M}, \mathrm{PH}, \mathrm{i}}+0.5 \mathrm{M}_{\mathrm{CM}, \mathrm{PH}, \mathrm{i}}+0.5 \mathrm{M}_{\mathrm{H}, \mathrm{PH}, \mathrm{i}}+0.35 \mathrm{M}_{\mathrm{SD}, \mathrm{PH}, \mathrm{i}}+1.85 \mathrm{M}_{\mathrm{CS}, \mathrm{PH}, \mathrm{i}}+ \\
& 1.85 \mathrm{M}_{\mathrm{HS}, \mathrm{PH}, \mathrm{i}}+2.7 \mathrm{M}_{\mathrm{S}, \mathrm{PH}, \mathrm{i}} \mathrm{lbmole} / \mathrm{hr} \\
& \mathrm{M}_{\mathrm{O}, \mathrm{CS}, 1}= 2 * 0+0.5 * 0+0.5 * 0+0.35 * .49+1.85 * 0+1.85 * 0+2.7 * 0=157.2 \\
& \mathrm{M}_{\mathrm{O}, \mathrm{CS}, \mathrm{all}}= 2 \mathrm{M}_{\mathrm{M}, \mathrm{PH}, \mathrm{i}}+0.5 \mathrm{M}_{\mathrm{CM}, \mathrm{PH}, \mathrm{i}}+0.5 \mathrm{M}_{\mathrm{H}, \mathrm{PH}, \mathrm{i}}+0.5 \mathrm{M}_{\mathrm{SD}, \mathrm{PH}, \mathrm{i}}+2 \mathrm{M}_{\mathrm{CS}, \mathrm{PH}, \mathrm{i}}+ \\
& 2 \mathrm{M}_{\mathrm{HS}, \mathrm{PH}, \mathrm{i}}+3 \mathrm{M}_{\mathrm{S}, \mathrm{PH}, \mathrm{i}} \\
& \mathrm{M}_{\mathrm{O}, \mathrm{CS}, \mathrm{all}}= 20+0.5 * 0+0.5 * 0+0.5 * 449+2 * 0+2 * 0+3 * 0=224.5 \mathrm{lbmole} / \mathrm{hr} \\
& \text { if } \mathrm{M}_{\mathrm{O}, \mathrm{CS}, \mathrm{all}}>\mathrm{M}_{\mathrm{O}, \mathrm{PH}, \mathrm{i}} \text { then } \mathrm{M}_{\mathrm{O}, \mathrm{CS}, \mathrm{c}}=\mathrm{M}_{\mathrm{O}, \mathrm{CS}, \mathrm{all}}-\mathrm{M}_{\mathrm{O}, \mathrm{PH}, \mathrm{i}} \\
& \text { else } \mathrm{M}_{\mathrm{O}, \mathrm{CS}, \mathrm{c}}=0
\end{aligned}
$$

since 224.5 is not greater than 282.3 then

$\mathrm{M}_{\mathrm{O}, \mathrm{CS}, \mathrm{c}}=0 \mathrm{lbmole} / \mathrm{hr}$

$\mathrm{M}_{\mathrm{N}, \mathrm{CS}, \mathrm{c}}=3.76 \mathrm{M}_{\mathrm{O}, \mathrm{CS}, \mathrm{c}}=3.76 * 0=0 \mathrm{lbmole} / \mathrm{hr}$

$\mathrm{M}_{\mathrm{W}, \mathrm{CS}, \mathrm{c}}=1.611 * 0.018\left(\mathrm{M}_{\mathrm{O}, \mathrm{CS}, \mathrm{c}}+\mathrm{M}_{\mathrm{O}, \mathrm{CS}, \mathrm{c}}\right)=1.611 * 0.018(0+0)=0 \mathrm{lbmole} / \mathrm{hr}$

if $\mathrm{M}_{\mathrm{O}, \mathrm{CS}, \mathrm{all}}>\mathrm{M}_{\mathrm{O}, \mathrm{PH}, \mathrm{i}}$ then $\mathrm{M}_{\mathrm{O}, \mathrm{CS}, 1, \mathrm{o}}=\mathrm{M}_{\mathrm{O}, \mathrm{CS}, \mathrm{all}}-\mathrm{M}_{\mathrm{O}, \mathrm{CS}, 1}$

else $\mathrm{M}_{\mathrm{O}, \mathrm{CS}, 1,0}=\mathrm{M}_{\mathrm{O}, \mathrm{PH}, \mathrm{i}}-\mathrm{M}_{\mathrm{O}, \mathrm{CS}, 1}$

since 224.5 is not greater than 282.3 then

$\mathrm{M}_{\mathrm{O}, \mathrm{CS}, 1, \mathrm{O}}=\mathrm{M}_{\mathrm{O}, \mathrm{PH}, \mathrm{i}}-\mathrm{M}_{\mathrm{O}, \mathrm{CS}, 1}=282.3-157.2=125.2 \mathrm{lbmole} / \mathrm{hr}$

$\mathrm{M}_{\mathrm{N}, \mathrm{CS}, 1,0}=\mathrm{M}_{\mathrm{N}, \mathrm{PH}, \mathrm{i}}+\mathrm{M}_{\mathrm{N}, \mathrm{CS}, \mathrm{c}}=2,669+0=2,669 \mathrm{lbmole} / \mathrm{hr}$ 


$$
\begin{aligned}
& \mathrm{M}_{\mathrm{CD}, \mathrm{CS}, 1, \mathrm{o}}=\mathrm{M}_{\mathrm{CD}, \mathrm{PH}, \mathrm{i}}+\mathrm{M}_{\mathrm{M}, \mathrm{PH}, \mathrm{i}}+\mathrm{M}_{\mathrm{CM}, \mathrm{PH}, \mathrm{i}}+\mathrm{M}_{\mathrm{CS}, \mathrm{PH}, \mathrm{i}} \\
& \mathrm{M}_{\mathrm{CD}, \mathrm{CS}, 1, \mathrm{o}}=577+0+0+0+0=577 \mathrm{lbmole} / \mathrm{hr} \\
& \mathrm{M}_{\mathrm{W}, \mathrm{CS}, 1, \mathrm{O}}=\mathrm{M}_{\mathrm{H}, \mathrm{PH}, \mathrm{i}}+2 \mathrm{M}_{\mathrm{M}, \mathrm{PH}, \mathrm{i}}+\mathrm{M}_{\mathrm{HS}, \mathrm{PH}, \mathrm{i}}=0+0+2 * 0=0 \mathrm{lbmole} / \mathrm{hr} \\
& \mathrm{M}_{\mathrm{ST}, \mathrm{CS}, 1, \mathrm{O}}=0.7\left(\mathrm{M}_{\mathrm{SD}, \mathrm{PH}, \mathrm{i}}+2 \mathrm{M}_{\mathrm{S}, \mathrm{PH}, \mathrm{i}}+\mathrm{M}_{\mathrm{HS}, \mathrm{PH}, \mathrm{i}}+\mathrm{M}_{\mathrm{CS}, \mathrm{PH}, \mathrm{i}}\right) \\
& \mathrm{M}_{S T, C S, 1,0}=0.7(449+0+0+0+0)=314.3 \\
& \mathrm{M}_{\mathrm{SD}, \mathrm{CS}, 1, \mathrm{O}}=0.3\left(\mathrm{M}_{\mathrm{SD}, \mathrm{PH}, \mathrm{i}}+2 \mathrm{M}_{\mathrm{S}, \mathrm{PH}, \mathrm{i}}+\mathrm{M}_{\mathrm{HS}, \mathrm{PH}, \mathrm{i}}+\mathrm{M}_{\mathrm{CS}, \mathrm{PH}, \mathrm{i}}\right) \\
& \mathrm{M}_{S D, C S, 1,0}=0.3(449+0+0+0+0)=134.7 \\
& \Delta \mathrm{H}_{\mathrm{CS}, 1}=42,570 * 0.7 \mathrm{M}_{\mathrm{SD}, \mathrm{PH}, \mathrm{i}}+345,200 \mathrm{M}_{\mathrm{M}, \mathrm{PH}, \mathrm{i}}+104,000 \mathrm{M}_{\mathrm{H}, \mathrm{PH}, \mathrm{i}}+ \\
& 121,700 \mathrm{M}_{\mathrm{CM}, \mathrm{PH}, \mathrm{i}}+315,000 \mathrm{M}_{\mathrm{S}, \mathrm{PH}, \mathrm{i}}+261,500 \mathrm{M}_{\mathrm{HS}, \mathrm{PH}, \mathrm{i}}+265,800 \mathrm{M}_{\mathrm{CS}, \mathrm{PH}, \mathrm{i}} \\
& \Delta \mathrm{H}_{\mathrm{CS}, 1}=42,570 * 0.7 * 449+345,200 * 0+104,000 * 0+121,700 * 0+315,000 * 0 \\
& +261,500 * 0+265,800 * 0=13.38 \mathrm{e}^{6}
\end{aligned}
$$

An energy balance can be made to determine the amount of air needed for cooling the first stage of the converter. Once this value is known, the total amount of moist dilution air can be determined; along with the molar flow rates exiting the drying tower (M6), second stage (M23), and entering the heat recovery preheater (M25).

$$
\begin{aligned}
& \mathrm{E}_{\mathrm{CS}, 1}=\sum_{\mathrm{k}=1}^{10} \mathrm{~h}_{\mathrm{j}}(779) \mathrm{M}_{\mathrm{k}, \mathrm{PH}, \mathrm{i}}+5,235.7 \mathrm{M}_{\mathrm{O}, \mathrm{CS}, \mathrm{c}}+5,028.4 \mathrm{M}_{\mathrm{N}, \mathrm{CS}, \mathrm{c}}+\Delta \mathrm{H}_{\mathrm{CS}, 1} \\
& \mathrm{E}_{\mathrm{CS}, 1}=7,456 * 577+5,068 * 0+8,082 * 0+4,888 * 0+6,202 * 0+7,779 * 0+ \\
& 5,028 * 2,669+5,236 * 282.3+5,869 * 0+7,680 * 449+5,236 * 0+5,028 * 0+ \\
& 13.38 \mathrm{e}^{6} \\
& \mathrm{E}_{\mathrm{CS}, 1}=36.03 \mathrm{e}^{6} \mathrm{Btu} / \mathrm{hr} \\
& E_{C S, 1, \max }=\sum_{j=1}^{6} \hat{h}_{j}(1158) M_{j, C S, 1,0} \\
& \mathrm{E}_{C S, \max }=11,980 * 577+7,859 * 2,669+8,226 * 125.2+12,290 * 134.7+16,970 * 314.3 \\
& +9,439 * 0 \\
& \mathrm{E}_{\mathrm{CS}, \max }=35.91 \mathrm{e}^{6} \mathrm{Btu} / \mathrm{hr} \\
& \text { where } \mathrm{k}=\mathrm{CD}, \mathrm{CM}, \mathrm{CS}, \mathrm{H}, \mathrm{HS}, \mathrm{M}, \mathrm{N}, \mathrm{O}, \mathrm{S}, \mathrm{SD} \\
& \text { and } \mathrm{j}=\mathrm{CD}, \mathrm{N}, \mathrm{O}, \mathrm{SD}, \mathrm{ST}, \mathrm{W} \\
& M_{\text {air,CS,ex }}=\frac{E_{C S, 1}-E_{C S, 1, \max }}{2,864.2}=\frac{36.03 \mathrm{e}^{6}-35.91 \mathrm{e}^{6}}{2,864.2}=42.53 \mathrm{lbmole} / \mathrm{hr}
\end{aligned}
$$




$$
\begin{aligned}
& \mathrm{M}_{\mathrm{BF}}=(1+1.611 * 0.018) \mathrm{M}_{\mathrm{air}, \mathrm{CS}, \mathrm{ex}}+\mathrm{M}_{\mathrm{O}, \mathrm{CS}, \mathrm{c}}+\mathrm{M}_{\mathrm{N}, \mathrm{CS}, \mathrm{c}}+\mathrm{M}_{\mathrm{W}, \mathrm{CS}, \mathrm{c}} \\
& \mathrm{M}_{\mathrm{BF}}=(1+1.611 * 0.018) 42.53+0+0+0=43.76 \mathrm{lbmole} / \mathrm{hr} \\
& \mathrm{M}_{\mathrm{D}, \mathrm{i}}=\mathrm{M}_{\mathrm{PH}, \mathrm{i}}+\mathrm{M}_{\mathrm{BF}}-0.3 \mathrm{M}_{\mathrm{W}, \mathrm{PH}, \mathrm{i}}=4845+43.76-0.3 * 868.0=4,629 \mathrm{lbmole} / \mathrm{hr} \\
& \mathrm{M}_{\mathrm{D}, \mathrm{O}}=\mathrm{M}_{\mathrm{D}, \mathrm{i}}-0.7 \mathrm{M}_{\mathrm{W}, \mathrm{PH}, \mathrm{i}}-1.611 * 0.018 \mathrm{M}_{\mathrm{air}, C S, \mathrm{ex}}-\mathrm{M}_{\mathrm{W}, \mathrm{CS}, \mathrm{c}} \\
& \mathrm{M}_{\mathrm{D}, \mathrm{o}}=4,629-0.7 * 868.0-1.611 * 0.018 * 43.76-0=4,020 \mathrm{lbmole} / \mathrm{hr} \\
& M_{23}=\sum_{k=1}^{6} M_{k, C S, 1,0}+M_{a i r, C S, e x}-0.5 * 0.83 M_{S D, C S, 1,0} \\
& \mathrm{M}_{23}=577+2,669+125.2+134.7+314.3+0+42.53-0.5 * 0.83 * 134.7 \\
& \mathrm{M}_{23}=3,807 \mathrm{lbmole} / \mathrm{hr} \\
& \mathrm{M}_{\mathrm{CD}, 25}=\mathrm{M}_{\mathrm{CD}, \mathrm{CS}, 1, \mathrm{o}}=577 \mathrm{lbmole} / \mathrm{hr} \\
& \mathrm{M}_{\mathrm{N}, 25}=\mathrm{M}_{\mathrm{N}, \mathrm{CS}, 1, \mathrm{c}}+0.79 \mathrm{M}_{\mathrm{air}, \mathrm{CS}, \mathrm{ex}}=2,669+0.79 * 42.53=2,702 \mathrm{lbmole} / \mathrm{hr} \\
& \mathrm{M}_{\mathrm{O}, 25}=\mathrm{M}_{\mathrm{O}, \mathrm{CS}, 1,0^{+}}+0.21 \mathrm{M}_{\mathrm{air}, \mathrm{CS}, \mathrm{ex}}-0.5 * 0.83 * \mathrm{M}_{\mathrm{SD}, \mathrm{CS}, 1, \mathrm{o}} \\
& \mathrm{M}_{\mathrm{O}, 25}=125.2+0.21 * 42.53-0.5 * 0.83 * 134.7 \\
& \mathrm{M}_{\mathrm{O}, 25}=78.19 \mathrm{lbmole} / \mathrm{hr} \\
& \mathrm{M}_{\mathrm{SD}, 25}=0.17 \mathrm{M}_{\mathrm{SD}, \mathrm{CS}, 1,0}=0.17 * 134.7=22.90 \mathrm{lbmole} / \mathrm{hr} \\
& M_{25}=\sum_{j=1}^{4} M_{j, 25}=577+270+78.18+22.90=3,381 \mathrm{lbmole} / \mathrm{hr} \\
& \text { where } \mathrm{k}=\mathrm{CD}, \mathrm{N}, \mathrm{O}, \mathrm{SD}, \mathrm{ST}, \mathrm{W} \\
& \text { and } \mathrm{j}=\mathrm{CD}, \mathrm{N}, \mathrm{O}, \mathrm{SD}
\end{aligned}
$$

The heat load on the heat recovery preheater can be determined now. The initial guess for the exit temperature is estimated by the ratio of the heat load to the inlet energy flow rate. This algorithm is used because it makes a very good initial guess for a wide range of inlet temperatures, compositions, and heat loads. Note that in Equations 3.62 and 3.64, the molar flow rates of the combustible gases are zero, and weren't shown in the calculation.

$$
\begin{aligned}
\mathrm{Q}_{\mathrm{HP}}= & \sum_{\mathrm{j}=1}^{4}\left(\hat{\mathrm{h}}_{\mathrm{j}}(256)-\hat{h}_{\mathrm{j}}(180)\right) \mathrm{M}_{\mathrm{j}, 25} \\
\mathrm{Q}_{\mathrm{HP}}= & (1,715-961.0) * 577+(1,256-720.3) * 2,702+(1,285-732.3) * 78.19+ \\
& (1,802-1,017) * 22.29 \\
\mathrm{Q}_{\mathrm{HP}}= & 1.943 \mathrm{e}^{6} \mathrm{Btu} / \mathrm{hr}
\end{aligned}
$$




$$
\begin{aligned}
& \mathrm{E}_{\mathrm{HP}, \mathrm{i}}=\sum_{\mathrm{k}=1}^{11} \hat{\mathrm{h}}_{\mathrm{k}}\left(\mathrm{T}_{\mathrm{HP}, \mathrm{i}}\right) \mathrm{M}_{\mathrm{k}}=\sum_{\mathrm{k}=1}^{11} \hat{\mathrm{h}}_{\mathrm{k}}(2000) \mathrm{M}_{\mathrm{k}} \\
& \mathrm{E}_{\mathrm{HP}, \mathrm{i}}=22.78 \mathrm{e}^{3 * 577}+14.44 \mathrm{e}^{3 * 2,669}+15.18 \mathrm{e}^{3 * 282.3}+23.36 \mathrm{e}^{3 * 449}+ \\
& 17.92 \mathrm{e}^{3 * 868.0} \\
& \mathrm{E}_{\mathrm{HP}, \mathrm{i}}=82.01 \mathrm{e}^{6} \mathrm{Btu} / \mathrm{hr} \\
& \mathrm{T}_{\text {guess }}=\mathrm{T}_{\mathrm{HP}, \mathrm{i}}\left(1-\frac{\mathrm{Q}_{\mathrm{HP}}}{\mathrm{E}_{\mathrm{HP}, \mathrm{i}}}\right)=2,000\left(1-\frac{1.943 \mathrm{e}^{6}}{82.01 \mathrm{e}^{6}}\right)=1,953^{\circ} \mathrm{F} \\
& E_{\text {guess }}=\sum_{k=1}^{11} \hat{h}_{k}\left(T_{\text {guess }}\right) M_{k}=\sum_{k=1}^{11} \hat{h}_{k}(1,953) M_{k}
\end{aligned}
$$

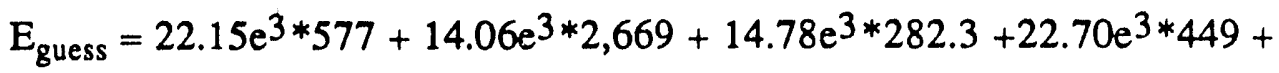

$$
\begin{aligned}
& 17.42 \mathrm{e}^{3 * 868.0} \\
& \mathrm{E}_{\text {guess }}=79.79 \mathrm{e}^{6} \mathrm{Btu} / \mathrm{hr} \\
& \text { where } \mathrm{j}=\mathrm{CD}, \mathrm{N}, \mathrm{O}, \mathrm{SD} \\
& \text { and } \mathrm{k}=\mathrm{CD}, \mathrm{CM}, \mathrm{CS}, \mathrm{H}, \mathrm{HS}, \mathrm{M}, \mathrm{N}, \mathrm{O}, \mathrm{S}, \mathrm{SD}, \mathrm{W} \\
& \mathrm{T}_{\mathrm{HP}, \mathrm{o}}=-\mathrm{Q}_{\mathrm{HP}} \frac{\mathrm{T}_{\mathrm{HP}, \mathrm{i}}-\mathrm{T}_{\text {guess }}}{\mathrm{E}_{\mathrm{HP}, \mathrm{i}}-\mathrm{E}_{\text {guess }}}+\mathrm{T}_{\mathrm{HP}, \mathrm{i}}=-1.943 \mathrm{e}^{6} \frac{2,000-1,953}{82.01 \mathrm{e}^{6}-79.79 \mathrm{e}^{6}}+2,000=1,959^{\circ} \mathrm{F}(3.6 \\
& \mathrm{LMTD}_{\mathrm{HP}}=\frac{\left(\mathrm{T}_{\mathrm{HP}, \mathrm{i}}-256\right)-\left(\mathrm{T}_{\mathrm{HP}, \mathrm{O}}-180\right)}{\ln \left(\frac{\mathrm{T}_{\mathrm{HP}, \mathrm{i}}-256}{\mathrm{~T}_{\mathrm{HP}, \mathrm{o}}-180}\right)}=\frac{(2,000-256)-(1,959-180)}{\ln \left(\frac{1,959-256}{2,000-180}\right)}=1,761^{\circ} \mathrm{F} \\
& \mathrm{A}_{\mathrm{HP}}=\frac{\mathrm{Q}_{\mathrm{HP}}}{4.5 \mathrm{LMTD}}=\frac{1.943 \mathrm{e}^{6}}{4.5^{*} 1,761}=245.1 \mathrm{ft}^{2}
\end{aligned}
$$

The amount of steam generated; along with, the heat and area of the boiler and superheater are determined in a similar manner to the heat recovery preheater. The energy flow rate exiting the heat recovery preheater is compared to the energy flow at $506^{\circ} \mathrm{F}$ to determine if any steam can be generated.

$$
\begin{aligned}
& \mathrm{E}_{\mathrm{HP}, \mathrm{O}}=\mathrm{E}_{\mathrm{HP}, \mathrm{i}}-\mathrm{Q}_{\mathrm{HP}}=82.01 \mathrm{e}^{6}-1.943 \mathrm{e}^{6}=80.07 \mathrm{Btu} / \mathrm{hr} \\
& \mathrm{E}_{506}=\sum_{\mathrm{k}=1}^{11} \hat{h}_{\mathrm{k}}(506) \mathrm{M}_{\mathrm{k}}
\end{aligned}
$$




$$
\begin{aligned}
& \mathrm{E}_{506}=4,366 * 577+3,040 * 2,669+3,143 * 282.3+4,527 * 449+3,556 * 868.0 \\
& \mathrm{E}_{506}=16.64 \mathrm{e}^{6} \mathrm{Btu} / \mathrm{hr} \\
& \text { and } \mathrm{k}=\mathrm{CD}, \mathrm{CM}, \mathrm{CS}, \mathrm{H}, \mathrm{HS}, \mathrm{M}, \mathrm{N}, \mathrm{O}, \mathrm{S}, \mathrm{SD}, \mathrm{W} \\
& \text { if } \mathrm{E}_{\mathrm{HP}, \mathrm{O}}>\mathrm{E}_{506} \text { then } \\
& \mathrm{E}_{\mathrm{GC}, \mathrm{i}}=\mathrm{E}_{506} \\
& \mathrm{~T}_{\mathrm{GC}, \mathrm{i}}=506 \\
& \text { else } \\
& \mathrm{E}_{\mathrm{GC}, \mathrm{i}}=\mathrm{E}_{\mathrm{HP}, \mathrm{O}} \\
& \mathrm{T}_{\mathrm{GC}, \mathrm{i}}=\mathrm{T}_{\mathrm{HP}, \mathrm{O}}
\end{aligned}
$$

since $80.07 \mathrm{e}^{6}$ is greater than $16.64 \mathrm{e}^{6}$

$$
\begin{aligned}
& \mathrm{E}_{\mathrm{GC}, \mathrm{i}}=16.64 \mathrm{e}^{6} \mathrm{Btu} / \mathrm{hr} \\
& \mathrm{T}_{\mathrm{GC}, \mathrm{i}}=506^{\circ} \mathrm{F} \\
& \mathrm{M}_{\mathrm{st}}=\frac{\mathrm{E}_{\mathrm{HP}, \mathrm{o}}-\mathrm{E}_{\mathrm{GC}, \mathrm{i}}}{\hat{\mathrm{h}}_{\mathrm{W}}\left(\mathrm{T}_{\text {specified }}\right)-2,134.8+17,929}=\frac{80.07 \mathrm{e}^{6}-16.64 \mathrm{e}^{6}}{3,934-2,134.8+17,92,9} \\
& \mathrm{M}_{\mathrm{st}}=3215 \mathrm{lbmole} / \mathrm{hr}
\end{aligned}
$$

Now the boiler and superheater heat loads, as well as, the log mean temperature differences, and areas can be determined. It should be noted that the model is not smart enough to determine whether the exit temperature of the heat recovery preheater is lower than the specified temperature of the steam. If this occurs a warning will be generated by Demos, when the model tries to evaluate the log mean temperature difference for the superheater. At this point the user should check the exit temperature of the heat recovery preheater and set the temperature of the steam accordingly.

$$
\begin{aligned}
& \mathrm{Q}_{\mathrm{b}}=17,929 \mathrm{M}_{\mathrm{st}}=17,929 * 3,215=57.65 \mathrm{e}^{6} \mathrm{Btu} / \mathrm{hr} \\
& \mathrm{Q}_{\mathrm{s}}=\left(\hat{h}_{\mathrm{W}}\left(\mathrm{T}_{\text {specified }}\right)-2134.8\right) \mathrm{M}_{\mathrm{st}}=(3,934-2,134.8) * 3,215=5,786 \mathrm{e}^{6} \mathrm{Btu} / \mathrm{hr} \\
& \mathrm{T}_{\text {guess }}=\mathrm{T}_{H P, o}\left(1-\frac{\mathrm{Q}_{\mathrm{s}}}{\mathrm{E}_{\mathrm{HP}, 0}}\right)=1,959\left(1-\frac{5.758 \mathrm{e}^{6}}{80.07 \mathrm{e}^{6}}\right)=1,817^{\circ} \mathrm{F} \\
& \mathrm{E}_{\text {guess }}=\sum_{\mathrm{k}=1}^{11} \hat{h}_{\mathbf{k}}\left(\mathrm{T}_{\text {guess }}\right) \mathrm{M}_{\mathbf{k}}=\sum_{\mathrm{k}=1}^{11} \hat{h}_{\mathbf{k}}(1,817) \mathrm{M}_{\mathrm{k}}
\end{aligned}
$$




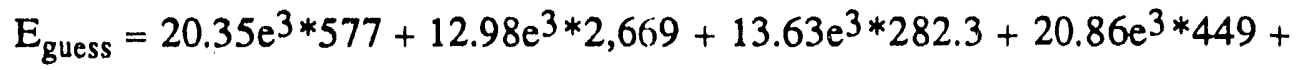

$$
\begin{aligned}
& 15.99 \mathrm{e}^{3 * 868.0} \\
& \mathrm{E}_{\text {guess }}=73.49 \mathrm{e}^{6} \mathrm{Btu} / \mathrm{hr} \\
& T_{b i, i}=-Q_{s} \frac{T_{H P, o}-T_{\text {guess }}}{E_{H P, o}-E_{\text {guess }}}+T_{H P, o}=-5.786 e^{6} \frac{1,959-1,817}{80.07 e^{6}-73.49 e^{6}}+1,959=1,834^{\circ} \mathrm{F} \\
& \mathrm{LMTD}_{\mathrm{s}}=\frac{\left(\mathrm{T}_{\mathrm{HP}, \mathrm{o}}-\mathrm{T}_{\text {specified }}\right)-\left(\mathrm{T}_{\mathrm{b}, \mathrm{i}}-338\right)}{\ln \left(\frac{\mathrm{T}_{\mathrm{HP}, \mathrm{o}}-338}{\mathrm{~T}_{\mathrm{b}, \mathrm{i}}-338}\right)}=\frac{(1,959-550)-(1,834-338)}{\ln \left(\frac{1,959-550}{1,834-338}\right)}=1,452^{\circ} \mathrm{F}(3 \\
& \mathrm{LMTD}_{b}=\frac{\left(T_{b, i}-338\right)-(506-226)}{\ln \left(\frac{T_{b, i}-338}{506-226}\right)}=\frac{(1,834-338)-(506-226)}{\ln \left(\frac{1,834-338}{506-226}\right)}=725.8^{\circ} \mathrm{F} \\
& A_{s}=\frac{Q_{s}}{6 \mathrm{LMTD}_{s}}=\frac{5.786 \mathrm{e}^{6}}{6 * 1,452}=664 \mathrm{ft}^{2} \\
& A_{b}=\frac{Q_{b}}{15 \operatorname{LMTD}_{b}}=\frac{57.65 \mathrm{e}^{6}}{15 * 725.8}=5,295 \mathrm{ft}^{2}
\end{aligned}
$$

The weak acid needed for the gas humidification and cooling tower, as well as, the electricity consumption of the compressors and pumps can be calculated now.

$$
\begin{aligned}
\mathrm{E}_{\mathrm{GC}, \mathrm{o}}= & \sum_{\mathrm{k}=1}^{11} \hat{\mathrm{h}}_{\mathrm{k}}(169) \mathrm{M}_{\mathrm{k}}-0.3 \hat{h}_{\mathrm{W}}(169) \mathrm{M}_{\mathrm{W}, \mathrm{HP}, \mathrm{i}} \\
\mathrm{E}_{\mathrm{GC}, \mathrm{o}}= & 854.7 * 577+643.1 * 2,669+653.2 * 282.3+905.2 * 449+742.9 * 868.0- \\
& 0.3 * 742.9 * 868.0 \\
\mathrm{E}_{\mathrm{GC}, \mathrm{O}}= & 3.252 \mathrm{e}^{6} \mathrm{Btu} / \mathrm{hr} \\
\mathrm{M}_{\mathrm{WA}}= & \frac{\mathrm{E}_{\mathrm{GC}, \mathrm{i}}-\mathrm{E}_{\mathrm{GC}, \mathrm{o}}+0.3\left(\hat{\mathrm{h}}_{\mathrm{W}}\left(\mathrm{T}_{\mathrm{GC}, \mathrm{i}}\right)-840.6+17,813\right) \mathrm{M}_{\mathrm{W}, \mathrm{HP}, \mathrm{i}}}{324.6} \\
\mathrm{M}_{\mathrm{WA}}= & \frac{16.64 \mathrm{e}^{6}-3.252 \mathrm{e}^{6}+0.3(3,556-840.6+17,813) 868.0}{324.6} \\
\mathrm{M}_{\mathrm{WA}}=57,7101 \mathrm{bmole} / \mathrm{hr} & \left.\left(\frac{1545 \mathrm{M}_{\mathrm{BF}}}{0.75 * 60 * 44240}\right)\left(\frac{1.4}{1.4-1}\right)\left(\frac{14.687+3.612 \mathrm{e}^{-2 * 67}}{14.687}\right)^{\frac{1.4-1}{1.4}}-1\right](80+460) \\
\mathrm{EC}_{\mathrm{BF}}= & \left(\frac{1,545 * 43.76}{0.75 * 60 * 44,240}\right)\left(\frac{1.4}{1.4-1}\right)\left[\left(\frac{14.687+3.612 \mathrm{e}^{-2 * 67}}{14.687}\right)^{\frac{1.4-1}{1.4}}-1\right](80+460) \\
\mathrm{EC}_{\mathrm{BF}}= &
\end{aligned}
$$




$$
\begin{aligned}
& \mathrm{EC}_{\mathrm{BF}}=2.862 \mathrm{~kW} \\
& \mathrm{EC}_{\mathrm{MC}}=\left(\frac{1545 \mathrm{M}_{\mathrm{D}, \mathrm{o}}}{0.75 * 60 * 44240}\right)\left(\frac{1.4}{1.4-1}\left[\left(\frac{14.687+3.612 \mathrm{e}^{-2 * 167}}{14.687+3.612 \mathrm{e}^{-2 * 51}}\right)^{\frac{1.4-1}{1.4}}-1\right](120+460)\right. \\
& \mathrm{EC}_{\mathrm{MC}}=\left(\frac{1,545 * 4,020}{0.75 * 60 * 44,240}\right)\left(\frac{1.4}{1.4-1}\left[\left(\frac{14.687+3.612 \mathrm{e}^{-2 * 167}}{14.687+3.612 \mathrm{e}^{-2 * 51}}\right)^{\frac{1.4-1}{1.4}}-1\right](120+460)\right. \\
& \mathrm{EC}_{\mathrm{MC}}=422.7 \mathrm{~kW} \\
& \mathrm{~m}_{\mathrm{acid}}=0.995\left(\mathrm{M}_{\mathrm{SD}, \mathrm{R}, \mathrm{O}}+\mathrm{M}_{\mathrm{CS}, \mathrm{R}, \mathrm{O}}+\mathrm{M}_{\mathrm{HS}, \mathrm{R}, \mathrm{O}}+2 \mathrm{M}_{\mathrm{S}, \mathrm{R}, \mathrm{o}}\right) 98 \mathrm{lbm} / \mathrm{lbmole} \\
& 12000 \text { tons } / \mathrm{lbm} \\
& m_{\text {acid }}=0.995(200+17+50+41) * 98 / 2000=21.89 \text { tons } / \mathrm{hr} \\
& \mathrm{EC}_{\mathrm{WA}}=\frac{120 \frac{\mathrm{lbf}}{\mathrm{in}^{2}} \mathrm{M}_{\mathrm{WA}}}{63,813 \frac{\mathrm{lbmole} / \mathrm{hr} * \mathrm{lbf} / \mathrm{in}^{2} * 0.80}{\mathrm{~kW}}} \\
& \mathrm{EC}_{\mathrm{WA}}=\frac{120 * 57,710}{63,813 * 0.8}=135.7 \mathrm{~kW} \\
& \mathrm{EC}_{\mathrm{SS}}=\frac{202.4 \frac{\mathrm{ga} ; \mathrm{om}}{\text { tons } / \mathrm{hr}} * 80 \mathrm{ft} \mathrm{m} \text { acid }}{2955 \frac{\mathrm{gal} / \mathrm{min} * \mathrm{ft}}{\mathrm{kW}} * 0.80} \\
& \mathrm{EC}_{\mathrm{SS}}=\frac{202.4 * 21.89 * 80}{2,955 * 0.8}=149.9 \mathrm{~kW} \\
& \mathrm{EC}_{\mathrm{PA}}=\frac{80 \frac{\mathrm{lbf}}{\mathrm{in}^{2}} \mathrm{~m}_{\text {acid }}}{1017 \frac{\text { tons } / \mathrm{hr} \mathrm{lbf} / \mathrm{in}^{2}}{\mathrm{~kW}} * 0.70} \\
& \mathrm{EC}_{\mathrm{PA}}=\frac{21.89 * 80}{1,017 * 0.7}=2.46 \\
& \mathrm{EC}_{\text {total }}=\mathrm{EC}_{\mathrm{IC}}+\mathrm{EC}_{\mathrm{GB}}+\mathrm{EC}_{\mathrm{BF}}+\mathrm{EC}_{\mathrm{MC}}+\mathrm{EC}_{\mathrm{WA}}+\mathrm{EC}_{\mathrm{SS}}+\mathrm{EC}_{\mathrm{PA}} \\
& \mathrm{EC}_{\text {total }}=249.3+321.8+2.862+422.7+135.7+149.9+2.46=1,285 \mathrm{~kW} \\
& \mathrm{EC}_{\mathrm{st}}=\frac{\mathrm{E}_{\mathrm{PH}, \mathrm{o}}-\mathrm{E}_{\mathrm{GC}, \mathrm{i}}}{0.88 \mathrm{HR}} \\
& \mathrm{EC}_{\mathrm{st}}=\frac{\mathrm{E}_{\mathrm{PH}, \mathrm{o}}-\mathrm{E}_{\mathrm{GC}, \mathrm{i}}}{0.88 \mathrm{HR}}=\frac{80.07 \mathrm{e}^{6}-16.64 \mathrm{e}^{6}}{0.88 * 9500}=7,587 \mathrm{~kW}
\end{aligned}
$$

The direct capitai cost of the power plant is calculated next. 
if $P_{R, 0}>47$ then

$$
\mathrm{DCC}_{\mathrm{IC}}=\$ 1.04 \mathrm{e}^{6}\left(\frac{\mathrm{G}_{\mathrm{R}, 0}}{35,000 \mathrm{ft}^{3} / \mathrm{min}}\right)^{0.6} \frac{\mathrm{C}_{\mathrm{idx}}}{314}
$$

else if $47<=P_{R, 0}<95$

$$
D_{C C}=\$ 5.64 \mathrm{e}^{6}\left(\frac{\mathrm{G}_{\mathrm{R}, \mathrm{o}}}{1.80 \mathrm{e}^{6} \mathrm{ft}^{3} / \mathrm{min}}\right)^{0.6} \frac{\mathrm{C}_{\mathrm{idx}}}{314}
$$

since $P_{R, 0}>47$

$\mathrm{DCC}_{\mathrm{IC}}=\$ 1.04 \mathrm{e}^{6}\left(\frac{\mathrm{G}_{\mathrm{R}, \mathrm{o}}}{35,000 \mathrm{ft}^{3} / \mathrm{min}}\right)^{0.6} \frac{\mathrm{C}_{\mathrm{idx}}}{314}=\$ 1.04 \mathrm{e}^{0.6}\left(\frac{24,290}{35,000}\right)^{0.6} \frac{316.9}{314}=\$ 843.0 \mathrm{e}^{3}$

$\mathrm{DCC}_{\mathrm{GB}}=\$ 7.07 \mathrm{e}^{5}\left(\frac{\mathrm{G}_{\mathrm{IC}, \mathrm{o}}}{68,000 \mathrm{ft}^{3} / \mathrm{min}}\right)^{0.6} \frac{\mathrm{C}_{\mathrm{idx}}}{314}=\$ 7.07 \mathrm{e}^{5}\left(\frac{21,870}{68,000}\right)^{0.6} \frac{316.9}{314}=\$ 361.2 \mathrm{e}^{3}(3.93)$

$\mathrm{DCC}_{\mathrm{HP}}=\$ 29,000\left(\frac{\mathrm{A}_{\mathrm{HP}}}{1,100 \mathrm{ft}^{2}}\right)^{0.6} \frac{\mathrm{C}_{\mathrm{idx}}}{316.9}=\$ 29,000\left(\frac{245.1}{1,100}\right)^{0.6} \frac{316.9}{316.9}=\$ 11.78 \mathrm{e}^{3}$

$\mathrm{DCC}_{\mathrm{b}}=\$ 53,000\left(\frac{\mathrm{A}_{\mathrm{b}}}{350 \mathrm{ft}^{2}}\right)^{0.6} \frac{\mathrm{C}_{\mathrm{idx}}}{316.9}=\$ 53,000\left(\frac{5,295}{350}\right)^{0.6} \frac{316.9}{316.9}=\$ 270.5 \mathrm{e}^{6}$

$\mathrm{DCC}_{\mathrm{s}}=\$ 80,000\left(\frac{\mathrm{A}_{\mathrm{s}}}{50 \mathrm{ft}^{2}}\right)^{0.6} \frac{\mathrm{C}_{\mathrm{idx}}}{316.9}=\$ 80,000\left(\frac{664.0}{50}\right)^{0.6} \frac{316.9}{316.9}=\$ 377.6 \mathrm{e}^{3}$

$\mathrm{DCC}_{\mathrm{GC}}=\$ 367,000\left(\frac{\mathrm{M}_{\mathrm{CC}}}{1,063 \mathrm{lbmole} / \mathrm{hr}}\right)^{0.6} \frac{\mathrm{C}_{\mathrm{idx}}}{316.9}=\$ 367,000\left(\frac{4,845}{1,063}\right)^{0.6} \frac{316.9}{316.9}$

$\mathrm{DCC}_{\mathrm{GC}}=\$ 911.9 \mathrm{e}^{3}$

$\mathrm{DCC}_{\mathrm{WA}}=\$ 39,000\left(\frac{\mathrm{M}_{\mathrm{WA}}}{19,250 \mathrm{lbmole} / \mathrm{hr}}\right)^{0.6} \frac{\mathrm{C}_{\mathrm{idx}}}{316.9}=\$ 39,000\left(\frac{57,710}{19,250}\right)^{0.6} \frac{316.9}{316.9}$

$\mathrm{DCC}_{\mathrm{WA}}=\$ 75.36 \mathrm{e}^{3}$

$D_{D C C}=\$ 636,000\left(\frac{M_{D, i}}{5,325 \mathrm{lbmole} / \mathrm{h} r}\right)^{0.6} \frac{C_{\mathrm{idx}}}{316.9}=\$ 636,000\left(\frac{4,629}{5,325}\right)^{0.6} \frac{316.9}{316.9}$

DCC $_{D}=\$ 586.7 \mathrm{e}^{3}$ 
$\mathrm{DCC}_{\mathrm{BF}}=\$ 518,000\left(\frac{\mathrm{M}_{\mathrm{BF}}}{4407 \mathrm{lbmole} / \mathrm{hr}}\right)^{0.6} \frac{\mathrm{C}_{\mathrm{idx}}}{316.9}=\$ 518,000\left(\frac{43.76}{4407}\right)^{0.6} \frac{316.9}{316.9}$

$\mathrm{DCC}_{\mathrm{BF}}=\$ 32.55 \mathrm{e}^{3}$

$\mathrm{DCC}_{\mathrm{CS}}=\$ 2,681,000\left(\frac{\mathrm{M}_{\mathrm{D}, \mathrm{o}}}{4854 \mathrm{lbmole} / \mathrm{hr}}\right)^{0.6} \frac{\mathrm{C}_{\mathrm{idx}}}{316.9}=\$ 2,681,000\left(\frac{4020}{4854}\right)^{0.6} \frac{316.9}{316.9}$

$\mathrm{DCC}_{\mathrm{CS}}=\$ 2.394 \mathrm{e}^{6}$

$\mathrm{DCC}_{\mathrm{T}}=\$ 988,000\left(\frac{\mathrm{M}_{23}}{4685 \mathrm{lbmole} / \mathrm{hr}}\right)^{0.6} \frac{\mathrm{C}_{\mathrm{idx}}}{316.9}=\$ 988,000\left(\frac{3807}{4685}\right)^{0.6} \frac{316.9}{316.9}$

$\mathrm{DCC}_{\mathrm{T}}=\$ 872.3 \mathrm{e}^{3}$

$\mathrm{DCC}_{\mathrm{SA}}=\$ 739,000\left(\frac{\mathrm{M}_{\mathrm{SD}, \mathrm{HP}, \mathrm{i}}+\mathrm{M}_{\mathrm{CS}, \mathrm{HP}, \mathrm{i}}+\mathrm{M}_{\mathrm{HS}, \mathrm{HP}, \mathrm{i}}+2 \mathrm{M}_{\mathrm{S}, \mathrm{HP}, \mathrm{i}}}{354 \mathrm{lbmole} / \mathrm{hr}}\right)^{0.6} \frac{\mathrm{C}_{\mathrm{idx}}}{316.9}$

$\mathrm{DCC}_{\mathrm{SA}}=\$ 739,000\left(\frac{449+0+0+0}{354}\right)^{0.6} \frac{316.9}{316.9}=\$ 852.3 \mathrm{e}^{3}$

$\mathrm{DCC}_{\mathrm{ES}}=\$ 70,000\left(\frac{\mathrm{M}_{\mathrm{GC}, \mathrm{i}}}{1,063 \mathrm{lbmole} / \mathrm{hr}}\right)^{0.6} \frac{\mathrm{C}_{\mathrm{idx}}}{316.9}=\$ 70,000\left(\frac{4,845}{1,063}\right)^{0.6} \frac{316.9}{316.9}$

$\mathrm{DCC}_{\mathrm{ES}}=\$ 173.9 \mathrm{e}^{3}$

$\mathrm{DCC}_{\text {total }}=\sum_{\mathrm{k}=1}^{13} \mathrm{DCC}_{\mathrm{k}}=\$ 843.0 \mathrm{e}^{3}+\$ 361.2 \mathrm{e}^{3}+\$ 11.78 \mathrm{e}^{3}+\$ 270.5 \mathrm{e}^{3}+\$ 377.6 \mathrm{e}^{3}+(3.105)$ $\$ 911.9 \mathrm{e}^{3}+\$ 75.36 \mathrm{e}^{3}+\$ 584.7 \mathrm{e}^{3}+\$ 32.55 \mathrm{e}^{3}+\$ 2,394 \mathrm{e}^{3}+\$ 872.3 \mathrm{e}^{3}+$ $\$ 852.3 \mathrm{e}^{3}+\$ 173.9 \mathrm{e}^{3}$

$\mathrm{DCC}_{\text {total }}=\$ 7.761 \mathrm{e}^{6}$

$\mathrm{TCC}_{\mathrm{acid}}=(1+0.275+0.419+0.081) \mathrm{DCC}_{\text {total }}=1.776 \mathrm{DCC}_{\text {total }}$

$\mathrm{TCC}_{\mathrm{acid}}=1.776 * \$ 7.761 \mathrm{e}^{3}=\$ 13.784 \mathrm{e}^{3}$

Now the operating cost are calculated.

$$
\begin{aligned}
& O C_{\text {oper }}=2 \text { persons } * 19.70 \$ / \mathrm{hr} * 8766 \mathrm{hrs} / \mathrm{yr} * \mathrm{C}_{\mathrm{idx}} / 325.3 \\
& O C_{\text {oper }}=2 * 19.70 * 8766 * 316.9 / 325.3=\$ 336.5 \mathrm{e}^{3} / \mathrm{yr} \\
& O C_{\text {maint-labor }}=2 \text { persons } * 19.70 \$ / \mathrm{hr} * 8766 \mathrm{hrs} / \mathrm{yr} / 3 * \mathrm{C}_{\mathrm{idx}} / 325.3 \\
& O C_{\text {maint-labor }}=2 * 19.70 * 8766 / 3 * 316.9 / 325.3=\$ 112.3 \mathrm{e}^{3} / \mathrm{yr} \\
& O C_{\text {admin }}=0.30\left(\mathrm{OC}_{\mathrm{oper}}+O C_{\text {maint-labor }}\right)
\end{aligned}
$$


61

$$
\begin{aligned}
& O C_{a d m i n}=0.30\left(336.5 \mathrm{e}^{3}+112.3 \mathrm{e}^{\mathrm{e}}\right)=\$ 134.6 \mathrm{e}^{3 / \mathrm{yr}} \\
& \mathrm{OC}_{\text {maint-mater }}=0.009 \mathrm{DCC}_{\text {total }}=0.009 * 7.761 \mathrm{e}^{6}=69.85 \mathrm{e}^{3} / \mathrm{yr} \\
& \mathrm{OC}_{\text {makeup }}=0.02 * 35.285 \$ / \mathrm{lbmole} / \mathrm{hr} * \mathrm{M}_{6} * \mathrm{C}_{\mathrm{idx}} / 325.3 \\
& \mathrm{OC}_{\text {makeup }}=0.02 * 35.2 * 4,020 * 316.9 / 325.3=\$ 2,757 / \mathrm{yr} \\
& \mathrm{OC}_{\text {credit }}=5085 \$ / \text { ton } * \mathrm{CF} * 8766 * \mathrm{~m}_{\mathrm{acid}} * \mathrm{C}_{\mathrm{idx}} / 325 \\
& \mathrm{OC}_{\text {credit }}=50 * .65 * 8766 * 21.89 * 316.9 / 325.3=\$ 6,076 \mathrm{e}^{3} / \mathrm{yr} \\
& \mathrm{OC}_{\text {marketing }}=0.1 * \mathrm{OC}_{\text {credit }}=0.1 * 6,076 \mathrm{e}^{3}=\$ 607.6 \mathrm{e}^{3} / \mathrm{yr} \\
& O C_{\text {total }}=O C_{\text {over }}+O C_{\text {maint-labor }}+O C_{\text {admin }}+O C_{\text {main-mater }}+O C_{\text {makeup }} \\
& +\mathrm{OC}_{\text {marketing }}-\mathrm{OC}_{\text {credit }} \\
& \mathrm{OC}_{\text {total }}=\$ 336.5 \mathrm{e}^{3}+\$ 112.2 \mathrm{e}^{3}+\$ 134.6 \mathrm{e}^{3}+\$ 69.85 \mathrm{e}^{3}+\$ 2,757+\$ 607.6 \mathrm{e}^{3}-\$ 6,076 \mathrm{e}^{3} \\
& O C_{\text {total }}=1,264 \mathrm{e}^{3}-\$ 6,076 \mathrm{e}^{3}=-\$ 4,812 \mathrm{e}^{3}
\end{aligned}
$$




\subsection{References}

1. Frey, H.C. Performance and Economic Model of the Fluidized Bed copper Oxide Process. Masters Thesis, Carnegie-Mellon University. May 1987.

2. Ratafia-Brown, J., R. Hershey. Economic Evaluation of the Fluidized Bed-Copper Oxide Flue Gas Treatment Process and Integrated Sulfuric Acid Plant. Science Management Corporation, April 1983.

3. Ral ia-Brown, J., R. Hershey. Technical and Economics Evaluation of the Fluidized BedCopper Oxide Flue Gas Treatment Process and Integrated Sulfur-Producing Plants. Science Management Corporation, June 1983.

4. Private communication from S. Higgins, Monsanto Enviro-Chem, St. Louis, MO, dated February 5, 1988.

5. Private communication from S. Higgins, Monsanto Enviro-Chem, St. Louis, MO, dated April 15, 1988.

6. Keeth, R, J.E. Miranda, J.B. Reisdorf, R.W. Scheck. Economic Evaluation of FGD Systems. Vol. IV, EPRI, Palo Alto, CA, 1986.

7. Barin, I. and O. Knacke. Thermochemical Properties of Inorganic Substances. SpringerVerlag, New York, 1973.

8. Barin, I., O. Knacke and O. Kubaschewski. Thermochemical Properties of Inorganic Substances: Supplement Vol. 1. Springer-Verlag, New York, 1977.

9. Gibbs, C.W., Ed. New Compressed Air and Gas Data. Ingersool-Rand Co., Phillipsburg, 1971.

10. Bloyd, C.N., J.C. Molburg, E.S. Rubin and J.F. Skea, The State-Level Advanced Utility Simulation Model: Analytical Documentation, Chapter 5, The Pollution Control Module.

Cooperative Agreement CR808514, Final Report from Universities Research Group on Energy, to U.S. Environmental Protection Agency, Research Triangle Park, NC (November 1984).

11. TAG - Technical Assessment Guide, Volume 1: Electricity Supply - 1986. Electric Power Research Institute, P-4463-SR, Volume 1, December 1986.

12. Ratafia-Brown, J., R. Hershey. Modeling of the Regenerator Reactor for the Fluidized Bed Copper Oxide Flue Gas Treatment Process Science Management Corporation, May 1984. 


\section{A. Appendix. Thermodynamic Data}

This appendix documents the thermodynamic data used in the IEC model. This data includes the heats of reaction for chemicals processes occurring in the copper oxide, NOXSO, and sulfuric acid plant systems. All the data is from Barin and Knacke [7], or Barin, Knacke, and Kubaschewski [8], except for the enthalpy data for the alumina substrate. This data is from the SMC report [12]. All the enthalpies are set to zero at $77^{\circ} \mathrm{F}$, and are assumed to be at a constant pressure. The heats of reaction and formation are calculated at this temperature. All data are shown to four significant digits; however, at least six significant digits were used to calculate the heats of reaction. ${ }^{4}$ Table A.1 shows the heats of formation for 18 species, while Table A.2 shows the heats of reaction for 21 chemical reactions.

The enthalpy data for all the compounds is obtained by integrating polynomial correlations for the specific heat at constant pressure between $77^{\circ} \mathrm{F}$ and the specified temperature. The correlations are in $\mathrm{cal} /\left(\mathrm{g}\right.$-mole $\left.{ }^{\circ} \mathrm{K}\right)$, except for the alumina substrate, so they have to be converted to $\mathrm{Btu} /(\mathrm{lbmole} \mathrm{OR})$. The polynomial correlations are shown below. The values of the constants for all the species are shown in Table A.3.

$$
C_{p}=A+B e^{-3} T+\frac{C e^{5}}{T^{2}}+D e^{-6} T^{2}
$$

The correlation for the alumina substrate in $\mathrm{J} /\left(\mathrm{g}\right.$-mole $\left.{ }^{\circ} \mathrm{K}\right)$ is

$$
C_{p}=A e^{2}+B e^{-3} T+\frac{C e^{2}}{\sqrt{T}}+\frac{D e^{6}}{T^{2}}
$$

Integrating with respect to temperature and choosing $298.15^{\circ} \mathrm{K}$ as a reference temperature gives for Equation A.1 gives,

$$
\begin{aligned}
& \hat{h}=\int_{298.15}^{T_{K}}\left(A+B e^{-3} T+\frac{C e^{5}}{T^{2}}+D e^{-6} T^{2}\right) d T \\
& \hat{h}=\left(A T+\frac{B e^{-3} T^{2}}{2}-\frac{C e^{5}}{T}+\frac{D e^{-6} T^{3}}{3}\right) d T
\end{aligned}
$$

\footnotetext{
4 All the original data are in metric units and had to be converted to english units.
} 
Next evaluate Equation A.4 and substitute $\mathrm{H}_{298}$ for the constant terms. Converting from cal/gmole to Btu/lbmole by multiplying by 1.8 gives,

$$
\hat{\mathrm{h}}=1.8 \mathrm{AT}_{\mathrm{K}}+\frac{1.8 \mathrm{Be}^{-3} \mathrm{~T}_{\mathrm{K}}^{2}}{2}-\frac{1.8 \mathrm{Ce}^{5}}{\mathrm{~T}_{\mathrm{K}}}+\frac{1.8 \mathrm{De}^{-6} \mathrm{~T}_{\mathrm{K}}^{3}}{3}-1.8 \mathrm{H}_{298}
$$

However the input temperature is still in degrees Kelvin, and it is desirable to the temperature in degrees Fahrenheit. Substituting $T_{K}=\left(T_{F}+459.67\right) / 1.8$ gives,

$$
\begin{aligned}
\hat{\mathrm{h}}= & \frac{1.8 \AA\left(\mathrm{T}_{\mathrm{F}}+459.67\right)}{1.8}+\frac{1.8 \mathrm{Be}^{-3}\left(\mathrm{~T}_{\mathrm{F}}+459.67\right)^{2}}{2 * 1.8}-\frac{1.8^{2} \mathrm{Ce}^{5}}{\mathrm{~T}_{\mathrm{F}}+459.67} \\
& +\frac{1.8 \mathrm{De}^{-6}\left(\mathrm{~T}_{\mathrm{F}}+459.67\right)^{3}}{3 * 1.8^{3}}-1.8 \mathrm{H}_{298}
\end{aligned}
$$

simplifying yields,

$$
\begin{aligned}
\hat{h}= & A\left(T_{F}+459.67\right)+\frac{B e^{-3}\left(T_{F}+459.67\right)^{2}}{3.6}-\frac{3.24 C e^{-5}}{T_{F}+459.67}+\frac{\mathrm{De}^{-6}\left(T_{F}+459.67\right)^{3}}{9.72} \\
& -1.8 \mathrm{H}_{298}
\end{aligned}
$$

Equation A.7 is used as a function for all the species except for the alumina substrate, since its units are $\mathrm{Btu} / \mathrm{lb}$ and the correlation for the specific heat has a different form. The final form of the enthalpy equation for the alumina substrate is.

$$
\begin{aligned}
\hat{\mathrm{h}}= & 0.23901\left(\mathrm{Ae}^{2}\left(\mathrm{~T}_{\mathrm{F}}+459.67\right)+\frac{\mathrm{Be}^{3}\left(\mathrm{~T}_{\mathrm{F}}+459.67\right)}{3.6}+\mathrm{Ce}^{2} \sqrt{7.2\left(\mathrm{~T}_{\mathrm{F}}+459.67\right)}\right. \\
& \left.-\frac{3.24 \mathrm{De}^{6}}{\mathrm{~T}_{\mathrm{F}}+459.67}-1.8 \mathrm{H}_{298}\right) / 102
\end{aligned}
$$

The constant 0.23901 converts J to calories, while 102 is the molecular weight. 
Table A.1: Standard Heat of Formation

\begin{tabular}{lr}
\hline Species & $\begin{array}{c}\mathrm{H}_{\mathrm{O}}\left(77^{\circ} \mathrm{F}\right) \\
\text { Btu/lbmole }\end{array}$ \\
\hline $\mathrm{CH}_{4}$ & $-32,180$ \\
$\mathrm{CO}$ & $-47,560$ \\
$\mathrm{CO}$ & $-169,300$ \\
$\mathrm{COS}$ & $-61,020$ \\
$\mathrm{Cu}$ & 0 \\
$\mathrm{CuO}$ & $-67,050$ \\
$\mathrm{CuSO}$ & $-331,300$ \\
$\mathrm{H}_{2}$ & 0 \\
$\mathrm{H}_{2} \mathrm{O}$ & $-104,000$ \\
$\mathrm{H}_{2} \mathrm{~S}$ & -8820 \\
$\mathrm{~N}_{2}$ & 0 \\
$\mathrm{NH}_{3}$ & $-19,760$ \\
$\mathrm{NO}$ & 38,840 \\
$\mathrm{NO}_{2}$ & 14,240 \\
$\mathrm{O}_{2}$ & 0 \\
$\mathrm{~S}_{2}$ & 55,350 \\
$\mathrm{SO}_{2}$ & $-127,700$ \\
$\mathrm{SO}_{3}$ & $-170,300$ \\
\hline
\end{tabular}


Table A.2: Heats of Reactions

\begin{tabular}{|c|c|}
\hline Reaction & $\begin{array}{l}\Delta \mathrm{H}\left(77^{\circ} \mathrm{F}\right) \\
\text { Btu/lbmole }\end{array}$ \\
\hline $\begin{array}{l}\mathrm{CH}_{4}+\mathrm{O}_{2}=\mathrm{CO}_{2}+2 \mathrm{H}_{2} \mathrm{O} \\
\mathrm{CO}+0.5 \mathrm{O}_{2}=\mathrm{CO}_{2} \\
\mathrm{COS}+1.5 \mathrm{O}_{2}=\mathrm{CO}_{2}+\mathrm{SO}_{2} \\
\mathrm{COS}+1.85 \mathrm{O}_{2}=\mathrm{CO}_{2}+0.3 \mathrm{SO}_{2}+0.7 \mathrm{SO}_{3} \\
\mathrm{Cu}+0.5 \mathrm{O}_{2}=\mathrm{CuO} \\
\mathrm{CuO}+0.25 \mathrm{CH}_{4}=\mathrm{Cu}+0.25 \mathrm{CO}_{2}+0.5 \mathrm{H}_{2} \mathrm{O} \\
\mathrm{CuO}+\mathrm{CO}=\mathrm{Cu}+\mathrm{CO}_{2} \\
\mathrm{CuO}+\mathrm{H}_{2}=\mathrm{Cu}+\mathrm{H}_{2} \mathrm{O} \\
\mathrm{CuO}+\mathrm{SO}_{2}+0.5 \mathrm{O}_{2}=\mathrm{CuSO} \\
\mathrm{CuO}+\mathrm{SO}_{3}=\mathrm{CuSO} \\
\mathrm{CuSO}+0.5 \mathrm{CH}_{4}=\mathrm{Cu}+\mathrm{SO}_{2}+0.5 \mathrm{CO}_{2}+\mathrm{H}_{2} \mathrm{O} \\
\mathrm{CuSO}+2 \mathrm{CO}=\mathrm{Cu}+\mathrm{SO}_{2}+2 \mathrm{CO}_{2} \\
\mathrm{CuSO}+2 \mathrm{H}_{2}=\mathrm{Cu}_{4}+\mathrm{SO}_{2}+2 \mathrm{H}_{2} \mathrm{O} \\
\mathrm{H}_{2}+0.5 \mathrm{O}_{2}=\mathrm{H}_{2} \mathrm{O} \\
\mathrm{H}_{2} \mathrm{~S}+1.5 \mathrm{O}_{2}=\mathrm{H}_{2} \mathrm{O}+\mathrm{SO}_{2} \\
\mathrm{H}_{2} \mathrm{~S}+1.85 \mathrm{O}_{2}=\mathrm{H}_{2} \mathrm{O}+0.3 \mathrm{SO}_{2}+0.7 \mathrm{SO}_{3} \\
\mathrm{NO}+\mathrm{NH}_{3}+0.25 \mathrm{O}_{2}=\mathrm{N}_{2}+1.5 \mathrm{H}_{2} \mathrm{O} \\
\mathrm{NO}_{2}+2 \mathrm{NH}_{3}+0.5 \mathrm{O}_{2}=1.5 \mathrm{~N}_{2}+3 \mathrm{H}_{2} \mathrm{O} \\
\mathrm{S}_{2}+2 \mathrm{O}_{2}=2 \mathrm{SO}_{2} \\
\mathrm{~S}_{2}+2.7 \mathrm{O}_{2}=0.3 * 2 * \mathrm{SO}_{2}+0.7 * 2 * \mathrm{SO}_{3} \\
\mathrm{SO}_{2}+0.5 \mathrm{O}_{2}=\mathrm{SO}_{3}\end{array}$ & $\begin{array}{r}-345,200 \\
-121,700 \\
-236,000 \\
-265,800 \\
-67,050 \\
-19,240 \\
-54,680 \\
-36,980 \\
-136,500 \\
-93,940 \\
30,980 \\
-39,910 \\
-4500 \\
-104,000 \\
-222,900 \\
-261,500 \\
-175,100 \\
-286,800 \\
-255,400 \\
-315,000 \\
-42,570\end{array}$ \\
\hline
\end{tabular}


Table A.3: Constants for the Specific Heat Correlations

\begin{tabular}{|c|c|c|c|c|c|c|}
\hline Species & A & B & C & D & $\begin{array}{c}\mathrm{H}_{298} \\
\mathrm{cal} / \mathrm{g}-\mathrm{mole}\end{array}$ & $\begin{array}{c}\text { Temperature Range } \\
{ }^{\circ} \mathrm{K}\end{array}$ \\
\hline $\begin{array}{l}\mathrm{CH}_{4} \\
\mathrm{CO} \\
\mathrm{CO}_{2} \\
\mathrm{COS} \\
\mathrm{Cu}(\mathrm{s}) \\
\mathrm{CuO}(\mathrm{s}) \\
\mathrm{CuSO}_{4}(\mathrm{~s}) \\
\mathrm{H}_{2} \\
\mathrm{H}_{2} \mathrm{O} \\
\mathrm{H}_{2} \mathrm{~S} \\
\mathrm{~N}_{2} \\
\mathrm{NH}_{3}\end{array}$ & $\begin{array}{r}2.975 \\
6.790 \\
10.550 \\
11.330 \\
5.940 \\
10.476 \\
17.545 \\
6.520 \\
7.170 \\
7.020 \\
6.660 \\
6.165\end{array}$ & $\begin{array}{r}18.329 \\
0.980 \\
2.160 \\
2.130 \\
0.905 \\
4.007 \\
36.532 \\
0.780 \\
2.560 \\
3.680 \\
1.020 \\
7.558\end{array}$ & $\begin{array}{r}0.346 \\
-0.110 \\
-2.040 \\
-1.830 \\
-0.332 \\
-1.406 \\
-2.942 \\
0.120 \\
0.080 \\
- \\
- \\
0.084\end{array}$ & $\begin{array}{r}-4.303 \\
- \\
- \\
- \\
- \\
-17.110 \\
- \\
- \\
- \\
- \\
-\end{array}$ & $\begin{array}{l}1,547.6 \\
2,104.9 \\
3,925.7 \\
4,088.7 \\
1,922.6 \\
3,773.1 \\
7,690.4 \\
1,938.4 \\
2,224.7 \\
2,256.6 \\
2,031.0 \\
2,145.9\end{array}$ & $\begin{array}{r}298-2000 \\
298-2500 \\
298-2500 \\
298-1800 \\
298-1357 \\
298-1359 \\
298-1078 \\
298-3000 \\
298-2500 \\
298-1800 \\
298-2500 \\
298-800\end{array}$ \\
\hline $\begin{array}{l}\mathrm{NO} \\
\mathrm{NO}_{2}\end{array}$ & $\begin{array}{r}12.601 \\
6.616 \\
8.529\end{array}$ & $\begin{array}{l}2.500 \\
1.778 \\
5.475\end{array}$ & $\begin{array}{l}-15.231 \\
-0.036 \\
-1.124\end{array}$ & $\begin{array}{r}- \\
-0.342 \\
-1.514\end{array}$ & $\begin{array}{r}7,590.5^{5} \\
2,060.6 \\
3,149.9\end{array}$ & $\begin{array}{l}800-2000 \\
298-3000 \\
298-1500\end{array}$ \\
\hline $\begin{array}{l}\mathrm{O}_{2} \\
\mathrm{~S}_{2} \\
\mathrm{SO}_{2} \\
\mathrm{SO}_{3}\end{array}$ & $\begin{array}{r}12.848 \\
7.160 \\
8.720 \\
10.380 \\
13.658\end{array}$ & $\begin{array}{l}0.305 \\
1.000 \\
0.160 \\
2.540 \\
6.536\end{array}$ & $\begin{array}{l}-0.400 \\
-0.900 \\
-1.420 \\
-3.086\end{array}$ & $\begin{array}{r}- \\
- \\
- \\
- \\
-1.847\end{array}$ & $\begin{array}{r}5,440.5^{6} \\
2,313.4 \\
2,908.8 \\
3,684,0 \\
4,972.4\end{array}$ & $\begin{array}{r}1,500-3000 \\
298-3000 \\
298-2000 \\
298-1800 \\
298-2000\end{array}$ \\
\hline $\mathrm{Al}_{2} \mathrm{O}_{3}(\mathrm{~s})^{7}$ & 1.534 & 1.968 & -9.006 & -2.031 & 20,804 & $298-1800$ \\
\hline
\end{tabular}

Note all species are assumed to be gaseous, except where noted.

\footnotetext{
5 Value of enthalpy at $800^{\circ} \mathrm{K}$.

6 Value of enthalpy at $1,500^{\circ} \mathrm{K}$.

7 Units of correlations $\mathrm{J} /\left(\mathrm{g}\right.$-mole $\left.{ }^{\circ} \mathrm{K}\right)$
} 

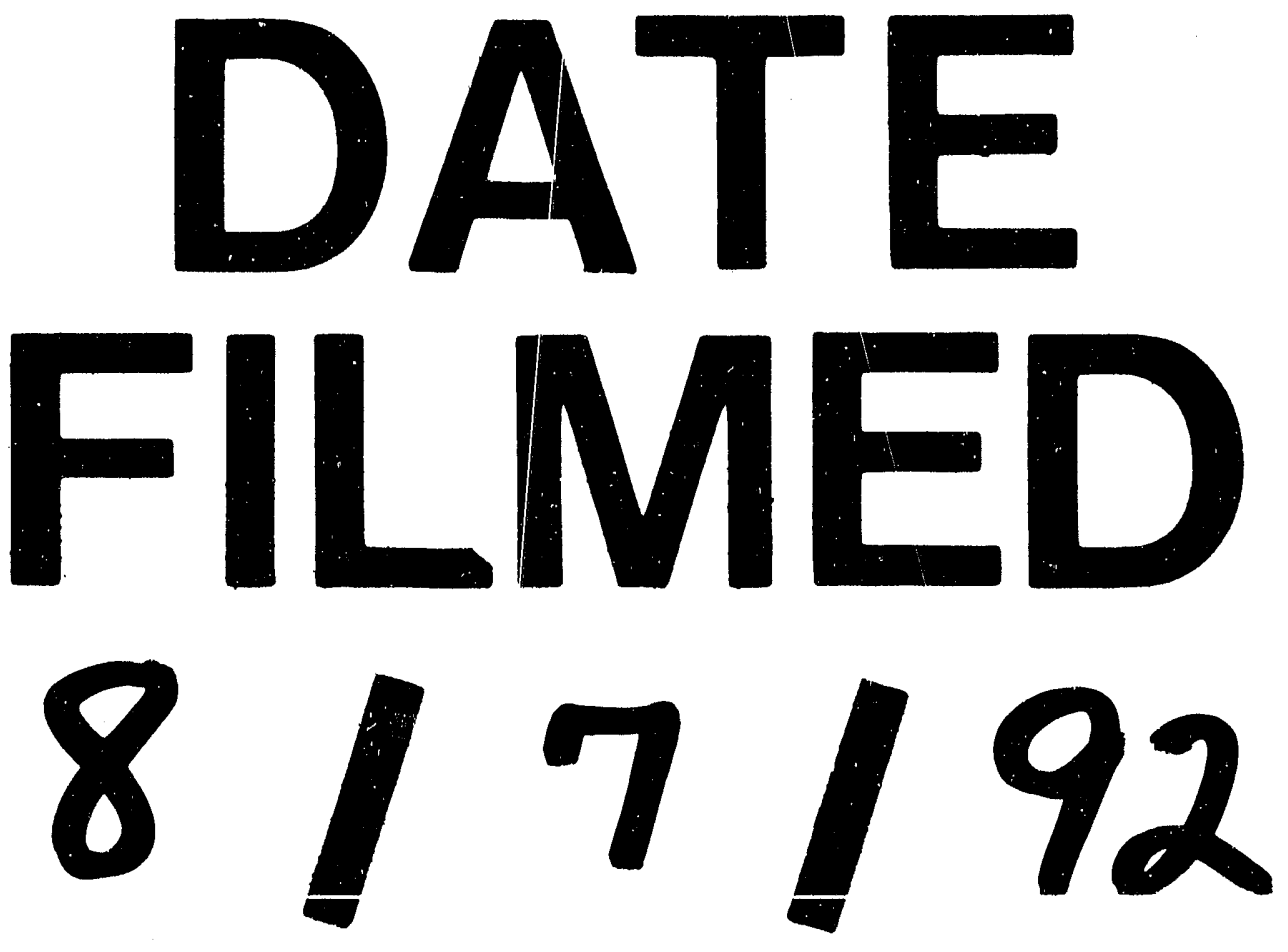
